OPEN ACCESS

Edited by:

Saurabh Chatterjee, University of South Carolina,

United States

Reviewed by: Ayan Mondal,

Stanford School of Medicine, United States

Ratanesh Kumar Seth, University of South Carolina,

United States

*Correspondence:

Carlos A. Labarrere clabarrere@sbcglobal.net

Specialty section:

This article was submitted to Inflammation,

a section of the journal

Frontiers in Immunology

Received: 12 January 2021

Accepted: 31 August 2021 Published: 23 September 2021

Citation:

Labarrere CA and Kassab GS (2021)

Pattern Recognition Proteins: First Line of Defense Against Coronaviruses.

Front. Immunol. 12:652252. doi: 10.3389/fimmu.2021.652252

\section{Pattern Recognition Proteins: First Line of Defense Against Coronaviruses}

\author{
Carlos A. Labarrere* and Ghassan S. Kassab \\ California Medical Innovations Institute, San Diego, CA, United States
}

The rapid outbreak of COVID-19 caused by the novel coronavirus SARS-CoV-2 in Wuhan, China, has become a worldwide pandemic affecting almost 204 million people and causing more than 4.3 million deaths as of August 11 2021. This pandemic has placed a substantial burden on the global healthcare system and the global economy. Availability of novel prophylactic and therapeutic approaches are crucially needed to prevent development of severe disease leading to major complications both acutely and chronically. The success in fighting this virus results from three main achievements: (a) Direct killing of the SARS-CoV-2 virus; (b) Development of a specific vaccine, and (c) Enhancement of the host's immune system. A fundamental necessity to win the battle against the virus involves a better understanding of the host's innate and adaptive immune response to the virus. Although the role of the adaptive immune response is directly involved in the generation of a vaccine, the role of innate immunity on RNA viruses in general, and coronaviruses in particular, is mostly unknown. In this review, we will consider the structure of RNA viruses, mainly coronaviruses, and their capacity to affect the lungs and the cardiovascular system. We will also consider the effects of the pattern recognition protein (PRP) trident composed by (a) Surfactant proteins A and D, mannose-binding lectin (MBL) and complement component 1q (C1q), (b) C-reactive protein, and (c) Innate and adaptive IgM antibodies, upon clearance of viral particles and apoptotic cells in lungs and atherosclerotic lesions. We emphasize on the role of pattern recognition protein immune therapies as a combination treatment to prevent development of severe respiratory syndrome and to reduce pulmonary and cardiovascular complications in patients with SARS-CoV-2 and summarize the need of a combined therapeutic approach that takes into account all aspects of immunity against SARS-CoV-2 virus and COVID-19 disease to allow mankind to beat this pandemic killer.

\footnotetext{
Keywords: pattern recognition proteins, SARS-CoV-2, COVID- 19, acute respiratory distress syndrome, ATH atherosclerosis, surfactant proteins A and D (SP-A and SP-D), C-reactive protein, innate and adaptive IgM antibodies
} 


\section{INTRODUCTION}

Ribonucleic acid (RNA) viruses (orthomyxoviruses and coronaviruses) have been the origin of many epidemics and pandemics over the years, such as $\mathrm{H} 1 \mathrm{~N} 1$, severe acute respiratory syndrome coronavirus (SARS-CoV) and Middle East respiratory syndrome coronavirus (MERS $\mathrm{CoV}$ ). One hundred years after the 1918-1919 catastrophic and historic influenza A pandemic (1-3), the world is facing another pandemic due to the SARS-CoV-2 (4) (Figure 1A). Currently, there is no specific drug or vaccine against this deadly virus; therefore, there is a pressing need to understand the mechanism(s) through which this virus enters the host cell (5). Coronaviruses (CoVs), named for the crown-like spikes on its surface, are enveloped viruses containing single-stranded, nonsegmented, positive sense RNA genetic material (5-12). On their surface, coronaviruses have club-like protrusions constituted by the trimeric spike (S) glycoprotein. The coronavirus RNA genome encodes spike (S), envelope (E), membrane (M), and nucleocapsid (N) structural proteins, common to SARS-CoV, MERS-CoV and coronavirus disease 2019 (COVID-19) (Figure 1B) (13). The SARS$\mathrm{CoV}$ and MERS-CoV genomic RNA is inside the $\mathrm{N}$ protein, while the $\mathrm{M}, \mathrm{E}$, and $\mathrm{S}$ proteins conform the envelope that surrounds the capsid (Figure 1B). The human CoVs S protein (Figure 1C) facilitates host cell virus entry and subsequent membrane fusion allowing viral infection (13). The Class I viral S protein can be cleaved into two functional subunits: 1) An amino-terminal S1 subunit, and 2) A carboxyl-terminal S2 subunit. The S1 subunit causes virus-host cell receptor binding to the cell surface receptor angiotensin-converting enzyme 2 (ACE2) receptor through the receptor binding domain and the S2 subunit allows virus-host membrane fusion (Figure 1C). SARS-CoV-2 is then taken up into the target cell through endocytosis. The viral envelope contains the (a) M glycoprotein (most abundant structural protein embedded in the envelope through three transmembrane domains), and (b) Small E transmembrane protein being in the envelope in low amounts (14). The helically symmetric nucleocapsid is formed by the binding of $\mathrm{N}$ protein to the RNA genome in a beads-on-astring fashion.

Seven CoVs are known to infect humans and cause respiratory diseases with mild to severe outcomes, while other CoVs infect animals such as pigs and chickens (14) (Figure 1A).

\footnotetext{
Abbreviations: RNA, Ribonucleic acid; SARS-CoV, Severe acute respiratory syndrome coronavirus; MERS-CoV, Middle East respiratory syndromecoronavirus; H, Hemagglutinin; N, Neuraminidase; CoVs, Coronaviruses; CRP, C-reactive protein; S, Spike protein; E, Envelope protein; M, Membrane protein; N, Nucleocapsid protein; COVID-19, Coronavirus disease-2019; ACE2, Angiotensin-converting enzyme 2; ARDS, acute respiratory distress syndrome; PRP, pattern recognition protein; MBL, mannose-binding lectin; $\mathrm{Clq}$, complement component 1q; nCRP, Native C-reactive protein; nnCRP, Nonnative C-reactive protein; mCRP, Monomeric C-reactive protein; IgM, Immunoglobulin $\mathrm{M}$; nIgM, Natural (innate) IgM; iIgM, Immune (adaptive) IgM; SP-A, Surfactant protein A; SP-D, Surfactant protein D; LRP1, Lowdensity lipoprotein receptor-related protein 1; CRT, Calreticulin; TGF- $B$, transforming growth factor- $\beta$; TNF- $\alpha$, Tumor necrosis factor- $\alpha$; OSCAR, Osteoclast-associated receptor; $\operatorname{SIRP} \alpha$, Signal inhibitory regulatory protein $\alpha$; HDL, High-density lipoprotein; LDL, Low-density lipoprotein; oxLDL, Oxidized low-density lipoprotein; PC, phosphorylcholine; IgM NAbs, IgM natural antibodies.
}

CoVs are recognized as one of the viral causes of the common cold. Among all CoVs presently identified, SARS-CoV in 2002 to 2003, and MERS-CoV in 2012, are zoonotic and highly pathogenic provoking regional and global outbreaks (14). The high mortality rate in both pandemics ( $~ 9.6 \%$ in SARS-CoV and $\sim 35 \%$ in MERS-CoV) was associated with the development of fatal respiratory failure and acute respiratory distress syndrome called ARDS $(13,14)$. Since at present, no vaccine or specific antiviral drug are available for either SARS-CoV or MERS-CoV, it is paramount to 1) Enhance the host immune responses, 2) Improve the body's capacity to neutralize virus particles, and 3) Intensify removal of virus particles by the host macrophages to avoid virus-mediated cell invasion, damage and death; i.e., modulate the inflammatory response (15).

COVID-19 originated by the SARS-CoV-2 has reached a pandemic level (16). It was first identified in Wuhan, China in December 2019 and has infected almost 204 million and caused more than 4.3 million deaths worldwide with a $2.1 \%$ fatality rate (17). Two systems in the body are directly implicated in disease severity and mortality: respiratory and cardiovascular; since compromise of lungs, heart and vasculature significantly worsen outcome (18). The SARS-CoV-2 family of viruses mutates easily and infects mostly bats, pigs, small mammals, and humans. Recently, these viruses have become growing players in infectious-disease outbreaks around the world. COVID-19 affects the lower respiratory tract of the lung airways, mainly the alveoli where the exchange of oxygen and carbon dioxide occurs during respiration. This leads to respiratory distress due to alveolar damage accompanied by immunopathological lesions as the most frequent cause of death. Patients initially develop flu-like symptoms that can advance to development of shortness of breath and pneumonia-related complications necessitating a respirator. People of all ages have been infected, but individuals at greatest risk of serious illness are older individuals with chronic lung disease, diabetes, cancer, and/or cardiovascular disease (18-25). Clinical outcomes are worse in patients with COVID-19 having cardiovascular disease and risk factors such as hypertension, diabetes, and obesity. For example, patients with a long history of coronary artery disease and patients with risk factors for developing atherosclerotic cardiovascular disease have a markedly greater risk of developing an acute coronary syndrome during acute infections, which has also been found in epidemiologic and clinical studies of influenza (26-28) and other acute inflammatory disorders (19, 29). Chronic inflammation of the vessels associates with arterial intimal cholesterol-laden macrophages (foam cells), which increase the possibility of acquiring a severe COVID-19 infection (30, 31). A chronic inflammatory disease like atherosclerosis may be an ideal environment for SARS-CoV-2 to reproduce due to its high viral replication capacity in human cells which can lead to immune system dysregulation and hyperactivation of pro-inflammatory pathways with subsequent cytokine release contributing to the cytokine storm $(30,31)$. This process can accelerate the progression of the disease and predispose the arteries to further develop atherothrombotic complications $(30,31)$. 

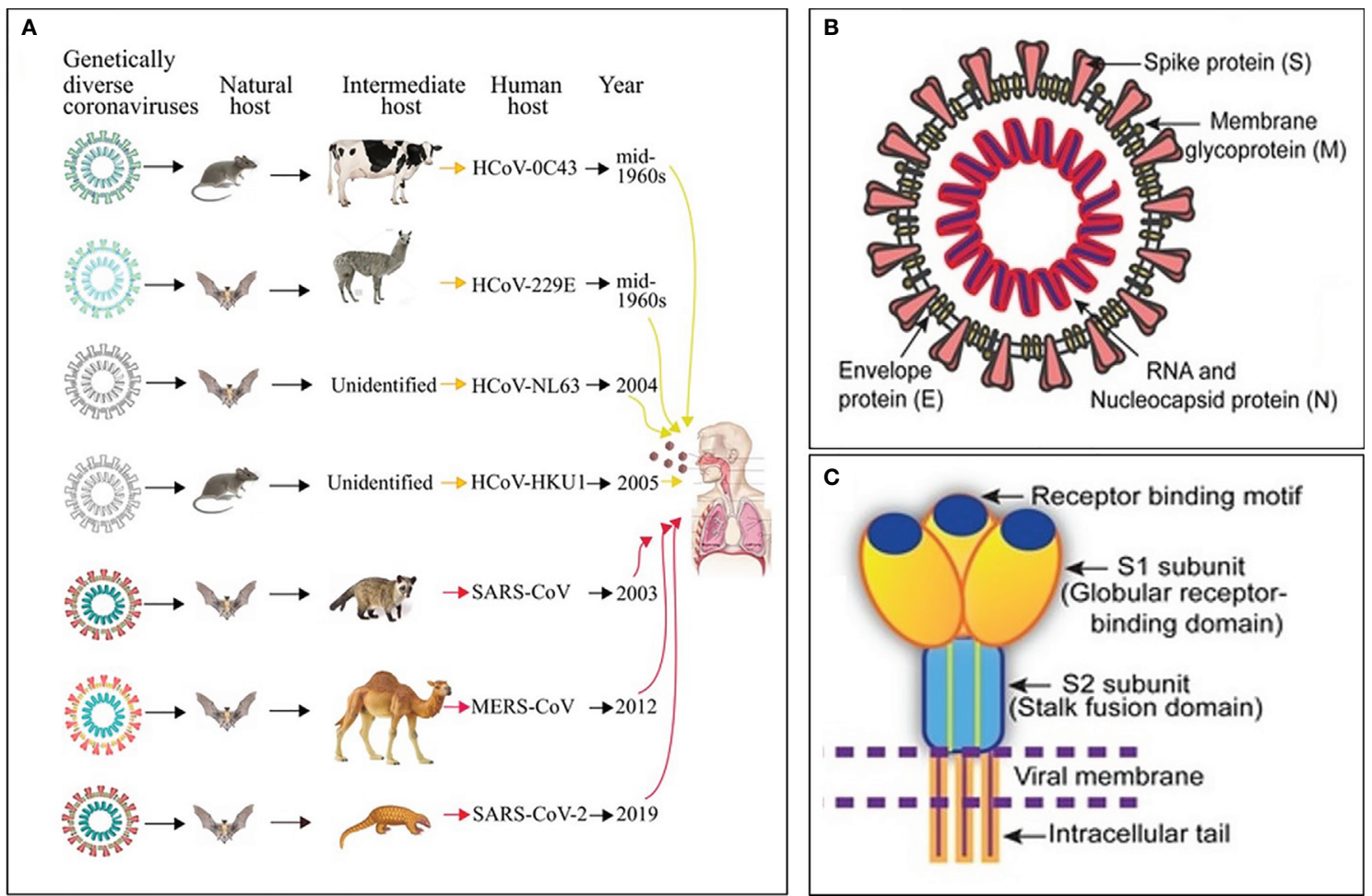

FIGURE 1 | Origin, transmission and structure of pathogenic human coronaviruses (HCoVs). (A) Yellow and red arrows represent mild and severe infections in humans, respectively. (B) Schematic diagram of the SARS-CoV structure. (C) Cartoon showing key features and the trimeric structure of the SARS-CoV-2 S protein. Modified from Mittal et al., (5).

SARS-CoV-2 is particularly different from SARS-CoV and MERS-CoV regarding global epidemiology and its impact on the cardiovascular system (18). COVID-19 is associated with an elevated inflammatory load that can lead to vascular inflammation and cardiac injury $(16,19)$. Acute cardiac injury, evidenced by elevations in cardiac troponin levels, is found in 8$62 \%$ of patients hospitalized with COVID-19 and is associated with greater disease severity, necessity for mechanical ventilation, and death (18). As described with other coronaviruses, SARS-CoV-2 can induce an enormous release of numerous cytokines and chemokines $(20,32,33)$ that can lead to vascular and myocardial inflammation and plaque instability (19). Circulating cytokines released during a severe systemic inflammatory response may lead to instability and rupture of atherosclerotic plaques. Coronary injury (e.g., coronary artery plaque inflammation, acute coronary syndrome and myocardial infarction) and failure have also been reported during the MERS$\mathrm{CoV}$ pandemic $(16,33)$. Patients at risk of myocardial injury are older and have higher levels of hypertension, coronary artery disease, heart failure, and diabetes than patients with normal levels of Troponin I or T. Patients with COVID-19 and myocardial injury also have more severe systemic inflammation, with increased leukocyte counts and elevated levels of C-reactive protein (CRP), procalcitonin and other biomarkers of myocardial injury and stress, like creatine kinase, myoglobin, and $\mathrm{N}$-terminal pro-B-type natriuretic peptide $(16,19,33-36)$. Patients who develop COVID-19associated cardiac injury have increased incidence of acute respiratory distress syndrome and need for assisted ventilation than patients without myocardial injury.

As SARS-CoV-2 enters the lung cells through the binding of viral $S$ protein to ACE2 (the functional receptor of SARS-CoV-2), it initiates replication. Although ACE2 is ubiquitous, it is more often expressed by lung epithelial cells, cells of the vascular system, and myocytes (37-41). The body recognizes all viruses as foreign invaders triggering an immune response to halt replication. The immune response to SARS-CoV-2 can also damage lung tissues through severe inflammation complicating pneumonia. Pneumonia causes alveoli to become inflamed and filled with fluid, making it harder to breathe and deliver oxygen to blood, potentially triggering a cascade of respiratory/cardiac complications. The lack of oxygen leads to more inflammation which may lead to further complications such as severe liver and kidney damage, and even death. Patients often must be placed on ventilators for weeks as they recover from the viral infection. As the number of patients requiring respirators surpasses the number of ventilators available in some hospitals and ICUs, the need for treatment halting the progression of disease becomes urgent. Pneumonitis in severe COVID-19 disease shows significant capillary injury with mural and luminal fibrin deposits, and neutrophil infiltration accompanied by deposits 
of complement components C4d and C5b-9 in the microvasculature (42). Severe inflammation may lead to a catastrophic microvascular injury syndrome mediated by a procoagulant state and complement activation (42). Endothelial injury can be directly generated by viral replication into the host cells and by ACE2 downregulation, that exposes cells to angiotensin 2 in the absence of the modulator effects of angiotensin 1-7 (37-41).

Importantly, viruses can induce an apoptotic cell death response at the end of their infectious cycle. During apoptosis, the cellular contents including the progeny virions are wrapped into plasma membrane-bound apoptotic bodies (the hallmark of apoptosis) which are quickly taken by surrounding cells. This impedes the development of an inflammatory response that allows the spreading of the infection without being detected (43). It was recently demonstrated that apoptotic bodies generated from influenza A-infected monocytes contain viral RNA, proteins, and virions promoting both viral propagation and antiviral immune response (44). Three major pathways such as apoptosis, necroptosis, and pyroptosis likely induce cell death in SARS-CoV-2-induced COVID-19 disease, directly through virus cell invasion or indirectly through intense cytokine and chemokine release causing immune cell damage (45-54). SARSCoV-2 promotes inflammation and could potentiate or accelerate the pre-existing systemic inflammatory state of individuals with obesity, diabetes, hypertension and other inflammatory diseases, through NOD-like receptor (NLR) family pyrin domain-containing 3 (NLRP3) inflammasome activation via cleavage and activation of key inflammatory molecules including active caspase-1 (Casp1p20), interleukin (IL)-1 $1 \beta$, and IL-18 and cell release of those pro-inflammatory cytokines through Gasdermin D pores commonly found in cell death by pyroptosis (45-54). Viral particles need to be cleared by macrophages with the help of the pattern recognition protein (PRP) trident composed by (a) Surfactant proteins A and D, mannose-binding lectin (MBL) and complement component $1 \mathrm{q}$ (C1q); (b) Native C-reactive protein (nCRP), non-native CRP (nnCRP) and monomeric CRP (mCRP); and (c) Natural (innate) immunoglobulin $\mathrm{M}$ (nIgM) and immune (adaptive) IgM (iIgM) (Figure 2).

\section{SURFACTANT PROTEINS, MANNOSE- BINDING LECTIN, COMPLEMENT 1Q, AND THE CORONAVIRUS}

Surfactant, a complex of $90 \%$ phospholipids (mostly dipalmitoylphosphatidylcholine), and $10 \%$ proteins, (mainly surfactant proteins (SP)-A, B, C and D) that lines the entire alveolar epithelium (Figure 3), plays a critical role in pulmonary innate immune defense $(55,56)$. Multimeric SP-A and SP-D are pattern recognition proteins and members of the collagencontaining C-type lectin (collectin) family that bind to repetitive carbohydrate moieties commonly found on the surface of viruses and other microbes in a $\mathrm{Ca}^{2+}$-dependent and carbohydrate-specific manner. This leads to virus agglutination and enhanced macrophages and neutrophil phagocytosis and killing (57, 58). Pulmonary surfactant is produced by alveolar type II cells expressing ACE2 receptors and are a direct target for SARS-CoV2 viral invasion. Indeed, ACE2 expression is predominantly observed in alveolar type II cells and alveolar macrophages and is strongly upregulated with age and alveolar damage associated with mechanical ventilation, being a potential mechanism for the increased mortality in patients with severe COVID-19 (59). After entry into the lungs, SARS-CoV-2 is proposed to destroy type II alveolar cells, the site for the synthesis of pulmonary surfactants, resulting in decreased production of pulmonary surfactant and leading to development of acute respiratory distress syndrome (60). Soluble ACE2 could be protective against SARS-CoV-2 since it has been found that the proteolytic cleavage-induced shedding of soluble ACE2 could protect against SARS-CoV-2 virus infection of alveolar type II cells (61-65) (Figure 3).

SP-A and SP-D direct interaction with various viruses more frequently results in viral neutralization and enhanced phagocytosis (57). SP-A and SP-D inhibit the hemagglutinin binding activity of influenza A virus; and SP-D also lowers neuraminidase activity (57). SP-D is a more potent inhibitor of influenza A virus infectivity than SP-A which induces massive aggregation of influenza A virus particles, inhibits hemagglutinin and neuraminidase activities, and neutralizes viral particles (57). Multivalent lectin-mediated interactions of SP-D with influenza A viruses result in viral aggregation, reduced epithelial infection, and enhanced virus clearance by phagocytic cells (66). SP-D has strong anti-influenza A viral activity through the binding of its carbohydrate recognition domain region to carbohydrates (mannosylated, N-linked) on viral hemagglutinin and neuraminidase (57). SP-D recognizes and binds the SARS coronavirus spike glycoprotein and enhances apoptotic cell ingestion by human activated macrophages $(57,67,68)$. A well characterized recombinant fragment of human SP-D, comprising the homotrimeric neck and the carbohydrate recognition domain region, able to reach distal lung locations due to its smaller size and higher resistance to proteases and collagenases compared to the full size SP-D, appear to contribute to significant inhibition of infectivity and replication of SARSCoV-2 present in the clinical samples derived from patients with asymptomatic, symptomatic, and severe COVID-19 (69). The ability of SP-D and recombinant fragment of human SP-D to bind SARS-CoV-2 S-protein suggest that they are capable of dampening the "cytokine storm" by rapid clearance of the virusinfected cells and strengthening the lung capacity by restoring homeostasis. Both, SP-A and SP-D have antiviral and immunomodulatory properties against SARS-CoV-2 (70, 71). SP-D participates in pulmonary viral neutralization, agglutination and clearance; reduction of the inflammatory response upon infection; enhancement of dendritic cell phagocytosis; enhancement of macrophage-mediated pathogen killing, inflammatory cytokine modulation and chemotaxis; modulation of intrapulmonary $\mathrm{T}$-cell response; promotion of clearance of apoptotic cells to prevent necrosis and inflammation; and binding of neutrophil/eosinophil extracellular traps preventing degranulation and modulating 


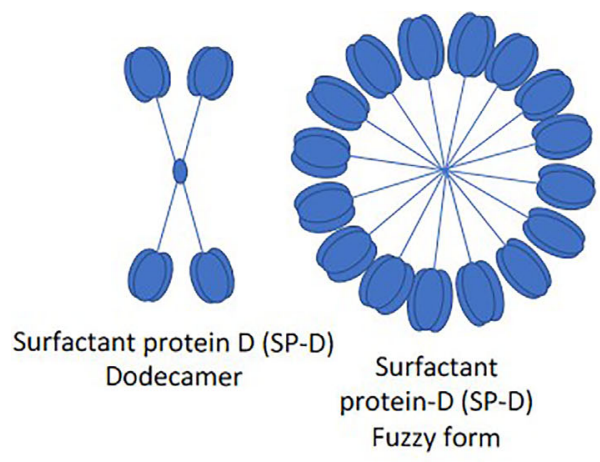

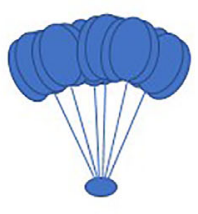

Surfactant protein-A (SP-A)

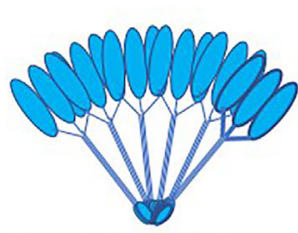

Mannose-binding lectin (MBL)

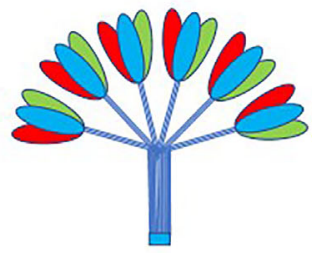

Complement component 1q (C1q)

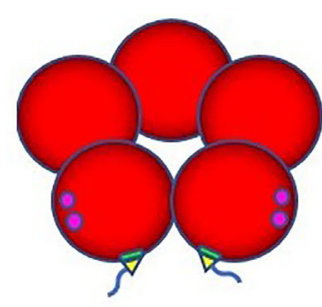

Native CRP (nCRP)
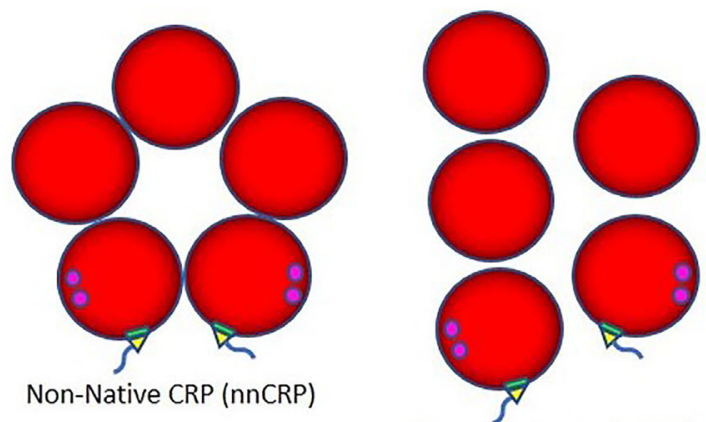

Monomeric CRP (mCRP)

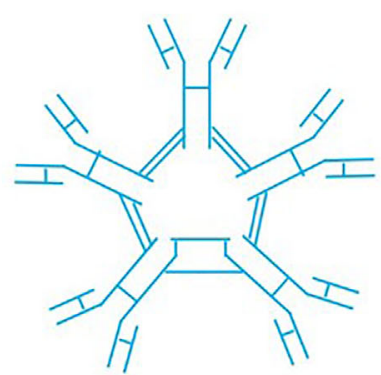

Natural (Innate) IgM

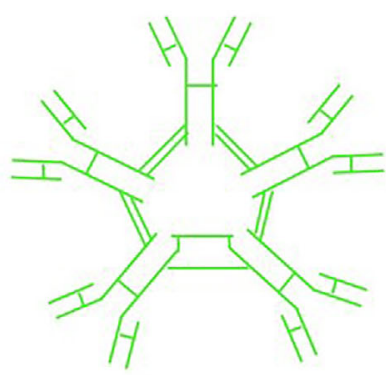

Immune (Adaptive) IgM

FIGURE 2 | Pattern recognition proteins. The trident of pattern recognition proteins is composed by: (Top) surfactant proteins D and A (SP-D and -A), mannosebinding lectin (MBL) and complement component 1q (C1q); (Middle) native C-reactive protein (nCRP), non-native CRP (nnCRP) and monomeric CRP (mCRP); and (Bottom) natural (innate) immunoglobulin $\mathrm{M}(\mathrm{IgM})$ and immune (adaptive) IgM.

cytokine production (70). SP-D recognizes SARS-CoV-2 Sprotein, and recombinant SP-D bound to S-protein has been shown to inhibit interaction of the S-protein with ACE2 receptors (71). The importance of SP-A and SP-D for lung protection against viral infections has been demonstrated by the increased susceptibility of SP-A and SP-D knockout mice to influenza A and respiratory syncytial virus infections and viralmediated inflammation (70). SP-D binds the heavily glycosylated SARS-CoV-2 S-protein (68); and SP-D levels, found to be elevated in severe SARS-CoV-2-related pneumonia, via leakage from the damaged lung into blood, may be used as biomarkers of clinical course, follow-up, determination of disease severity, and possibly future treatments for COVID-19 disease (72-76).

SP-A and SP-D bind to different surfactant protein receptors such as the complex CD91 (Low-density lipoprotein receptor- related protein 1, LRP1)-calreticulin (CRT) and signal inhibitory regulatory protein $\alpha$ (SIRP $\alpha$ ) (Figure 3). Both (a) SP-A or SP-D bound to a virus or apoptotic cell through its lectin domain, and (b) apoptotic cells opsonized with C1q or MBL, bind to the CD91-CRT receptor through the collagen-like domain to activate immune cells and facilitate removal (Figure 3); while blockage of CD91 reduces apoptotic cell macrophage uptake (56, 77-80). SP-A and SP-D bind to toll-like receptors that recognize pattern-associated molecular patterns bound to RNA from viruses, and lung collectins and MBL cause (a) virion agglutination, inhibition of infectivity and dissemination, and (b) subsequent alveolar macrophage and neutrophil-mediated removal (56-58). In a normal environment, SP-A and SP-D fulfil an anti-inflammatory role mediated by the binding of their Clectin domain to the SIRP $\alpha$ receptor (79). 


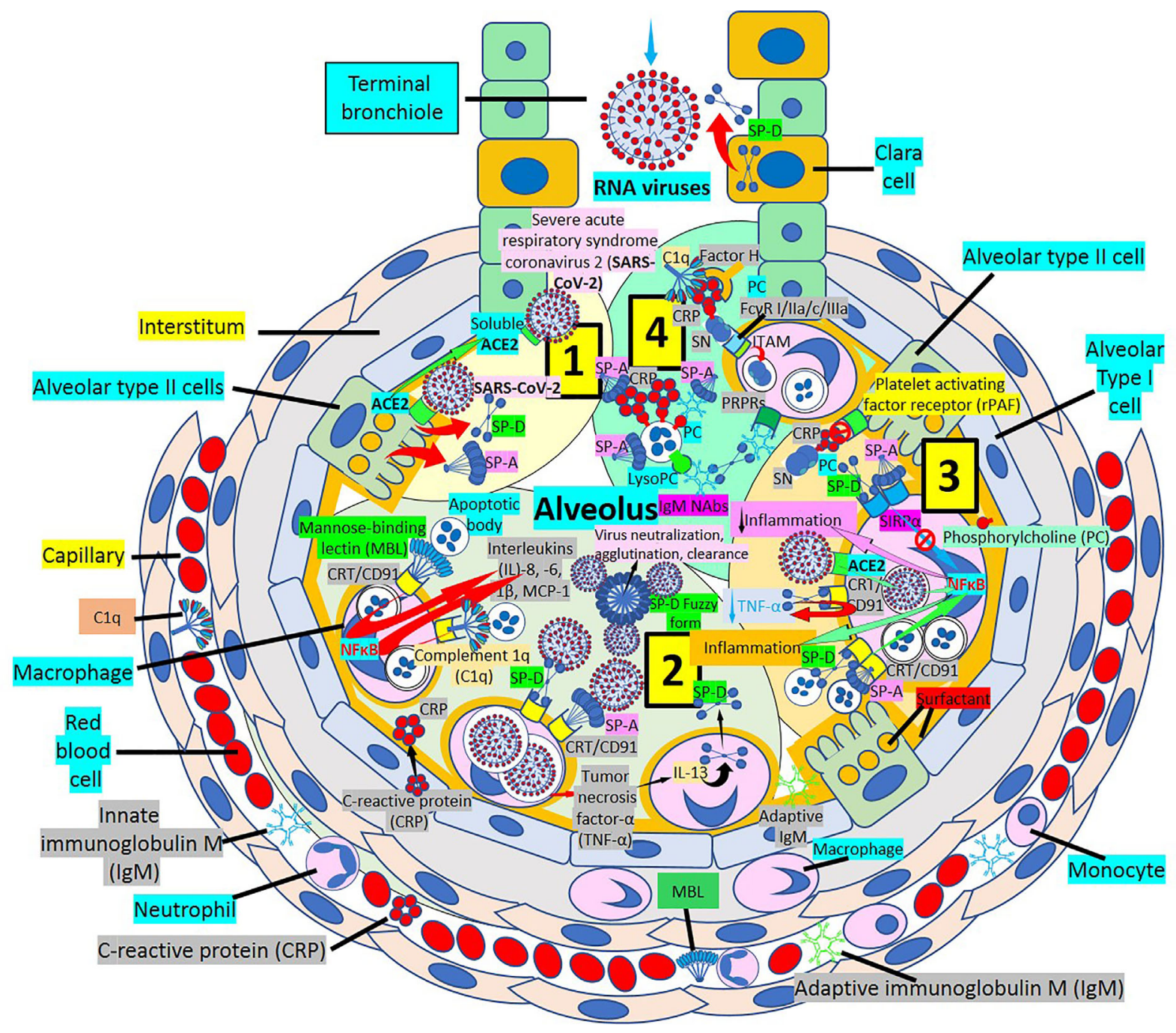

FIGURE 3 | Alveolar surfactant protein innate immune response to RNA viruses. [1] Intra-alveolar RNA viruses are exposed to surfactant proteins (SP)-A and -D produced by alveolar type II (All) and Clara cells. SARS-CoV-2 binds ACE2 receptors in All cells releasing soluble ACE2 to protect All cells against SARS-CoV-2 infection. [2] MBL and C1q bind calreticulin/CD91 (CRT/CD91) receptors enhancing apoptotic body macrophage uptake and nuclear factor $\mathrm{KB}$ (NFKB)-mediated intra-alveolar release of IL-1B, -6, -8 and monocyte chemoattractant protein-1 (MCP-1). CRT/CD91 bound SP-A and SP-D facilitate virus phagocytosis. TNF- $\alpha$ release stimulates IL-13-mediated SP-D macrophage output; and SP-D fuzzy form contributes to virus neutralization, agglutination and clearance. Circulating innate and adaptive IgM, MBL, C1q and CRP; and alveolar type I cell CRP synthesis and release contribute to alveolar immune defense. [3] CRT/CD91-bound SP-A and SP-D facilitate apoptosis and activate NFkB-mediated inflammation. Macrophage ACE2 facilitates virus uptake and SP-D-CRT/CD91 binding reduces TNF- $\alpha$ release. Signal inhibitory regulatory protein $\alpha$ (SIRP $\alpha$ ) SP-A and SP-D binding inhibits inflammation. Native CRP blocks PC-mediated attachment of streptococcus pneumoniae (SN) to rPAF on alveolar epithelial cells. PC is a main component of alveolar surfactant. [4] Interaction of SP-A, SP-D, CRP and IgM natural antibodies (NAbs) with apoptotic cells facilitate macrophage uptake through pattern recognition protein receptors (PRPRs). CRP bound to $\mathrm{C} 1 \mathrm{q}$ and factor $\mathrm{H}$ mediates SN uptake via Fc receptors and cytoplasmic immuno-tyrosine activating motif (ITAM) activation.

The SIRP $\alpha / C D 47$ axis has emerged as an important innate immune checkpoint that enables cancer cells and virus-infected cells escape from macrophage phagocytosis (81-83). SARS-CoV2-infected cells upregulate the CD47 "don't eat me" signal, that could be used as potential biomarker of severe COVID-19 disease (84), slowing the phagocytic uptake of dying and viable cells (82). Immune inhibitory receptors like SIRP $\alpha$ become upregulated during viral infection as a feedback mechanism to prevent immune overactivation. During severe SARS-CoV-2 infection inflammatory cell immunosuppression and dysregulation with the resulting upregulation of inhibitory immune receptors like SIRP $\alpha$, lead to immune exhaustion, suppression of innate and adaptive immune responses, and delayed interferon response with inefficient viral clearance, which could be directly induced by the virus as an evasion mechanism (85).

The most prevalent SP-D structure, the dodecameric conformation, seems to possess anti-inflammatory properties, 
while the trimeric or monomeric isoforms, are believed to have pro-inflammatory properties, when SP-D is in an inflammatory or more acidic environment (86-91). Surfactant is mainly produced in the lung, but surfactant mRNA and protein have also been identified in heart, arteries, kidney, and other organs $(56,86,92)$ (Figures 3, 4); and SP-A and SP-D seem to modulate the immune response by preventing excessive inflammation, as found in the cytokine storm caused by COVID-19, that can potentially damage the lungs and impair gas exchange (55). Pulmonary SP-D production can be enhanced by tumor necrosis factor- $\alpha$ (TNF- $\alpha$ )-mediated induction of IL-13 (90) (Figure 3). LRP1 (CD91)-bound SP-D may be antiatherogenic by decreasing TNF receptor-1 expression, attenuating nuclear factor-kB activation, limiting monocyte recruitment into atherosclerotic plaques, preventing macrophage apoptosis, and enhancing dying cell digestion limiting necrotic core formation (77, 93-95). C1q and MBL bind apoptotic cells that can be engulfed by macrophages following binding of their collagenous tails to CRT (cC1qR)/CD91 surface receptors (79). SP-A and SP-D interact with foreign organisms, like SARS-CoV-2, apoptotic cells or cell debris through LRP1/CRT-mediated macrophage phagocytosis and modulation of the inflammatory response in lungs and atherosclerotic plaques $(57,68,95)$. The ability of CRT/CD91 to scavenge microbial membrane lipoproteins and to digest apoptotic cells favors the control of local inflammation by preventing an overwhelming inflammatory response causing further injury, as found during SARS-CoV-2 infectionassociated hyperinflammation and cytokine storm $(70,96)$.

SP-D and the SP-D-receptor, osteoclast-associated receptor (OSCAR), are found in atherosclerotic plaques (86, 97-101) (Figures 4, 5), particularly in an inflammatory environment where TNF- $\alpha$ and oxidized low-density lipoprotein (oxLDL) induce SP-D and OSCAR expression, respectively (86, 97-104). SP-D promotes atherogenesis by 1) Lowering HDL levels, 2) Enhancing OSCAR-mediated macrophage TNF $\alpha$ production, 3) Inducing circulating monocytes and macrophage proliferation, 4) Enhancing foam cell accumulation and plaque formation and 5) Decreasing atherosclerotic plaque smooth muscle cell coverage $(97,99-101)$. In an inflammatory and oxidative environment, endothelial, smooth muscle and macrophage dodecameric SP-D production breaks apart into trimeric and monomeric isoforms (100-106); and in association with increased cytokine production in atherosclerosis, make this lesion more prone to SARS-CoV-2 infection, especially considering that advanced atherosclerotic lesions show increased ACE2 receptor expression (107, 108), the SARS$\mathrm{CoV}-2$ virus receptor. SARS-CoV-2 infection in the plaques contributes to diminished ACE2 regulation, exposing endothelial cells to angiotensin II in the absence of modulatory effects of angiotensin 1-7, worsening atherosclerosis (108).

In summary, SP-A and SP-D perform a dual role, antiinflammatory and proinflammatory, depending upon the part of the molecule that binds the receptor (C-lectin domains or collagenous tail region) and the type of receptor bound (CRT/ CD91 or signal inhibitory regulatory protein $\alpha, \operatorname{SIRP} \alpha)$. Furthermore, multimeric and trimeric/monomeric SP-D isoforms perform opposite functions during inflammation, promoting the idea of "good" and "bad" SP-D. Multimeric, mainly dodecameric or fuzzy form, will contribute to viral neutralization, agglutination and clearance, as well as removal of infected apoptotic cells, in lungs and atherosclerotic plaques. On the contrary, trimeric and monomeric SP-D isoforms generated during oxidative stress will enhance inflammation and disease progression in lungs, atherosclerotic lesions and other organs. Reduction in the generation of trimeric/ monomeric forms will be most probably associated with lowering the severity of pulmonary damage and plaque size and progression $(100,101,105)$. Deficiency of multimeric forms could be related to a proinflammatory environment with abnormal accumulation of apoptotic macrophages and foamy macrophages in lungs and plaques $(100,101,105)$. In a normal environment, SP-A and SP-D fulfil an anti-inflammatory role mediated by the binding of their C-lectin domain to the SIRP $\alpha$ receptor. During acute inflammation of the lungs, a deficient apoptotic cell clearance is overcome by the recruitment of mononuclear phagocytes and following the binding of foreign particles (viruses or apoptotic bodies) alveolar macrophages initiate inflammation and host defense reactions $(88,109)$. SP$\mathrm{D}$ and SP-A binding to alveolar macrophages during inflammation occurs via their C-lectin domain and subsequent binding to the CRT/CD91 receptor complex via their collagenous tail region $(88,109)$. Enhancement of apoptotic cell clearance during SARS-CoV-2 infection is paramount, especially when it has been shown that a dysfunctional efferocytosis in SARS-CoV-2-infected cell corpses suppresses macrophage anti-inflammation and efficient tissue repair allowing hyperinflammation and extensive tissue damage linked with COVID-19 (110).

COVID-19 disease originates in the lungs but affects multiple organs causing multiorgan damage in severe cases, and this tissue injury is primarily the result of hypercytokinemia and aggressive inflammation (111). The manifestations of severe COVID-19 such as the acute respiratory distress syndrome, sepsis and multiorgan failure have an established relationship with activation of the complement cascade (112). Collectins (SP-A, SP-D, and MBL) and $\mathrm{Clq}$, which is related to the collectins by structure and function, except that its globular head lacks lectin activity, are members of the innate immune system that play key roles in the early recognition and removal of microorganisms, modulation of the inflammatory response, and clearance of apoptotic cells (80); and the entire collectin family (including $\mathrm{Clq}$ ) works through a common receptor complex and are integral, organ-specific components of the clearance machinery (80).

\section{C-REACTIVE PROTEIN AND THE CORONAVIRUS}

\section{C-Reactive Protein and Inflammation}

C-reactive protein (CRP) discovered in 1930 by Tillett and Francis Jr is an acute-phase pattern recognition protein (PRP) 


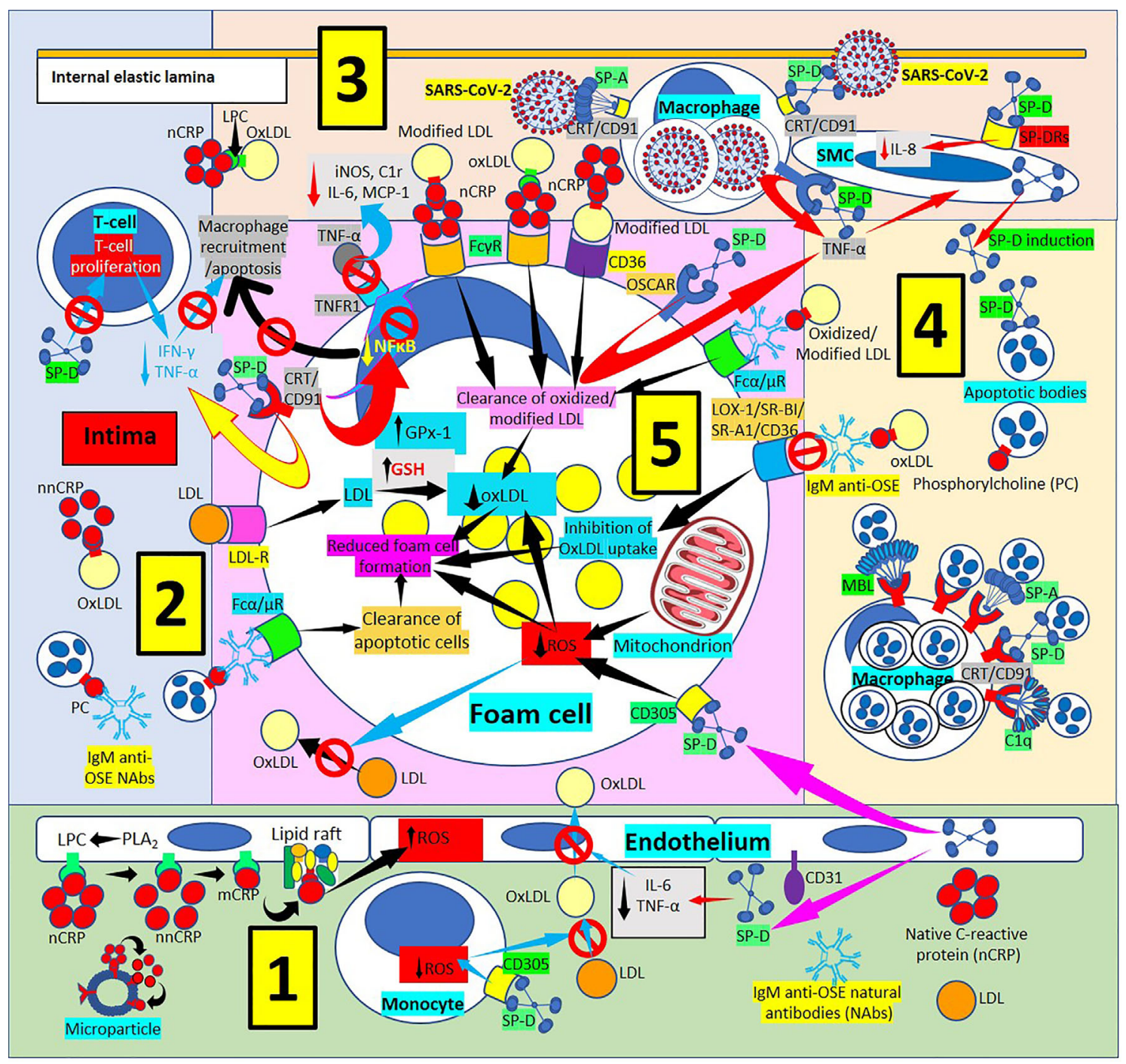

FIGURE 4 | Surfactant protein innate immunoprotective responses in atherosclerotic lesions. [1] SP-D can be synthesized by endothelial cells and released into plasma and arterial intima, and circulatory SP-D inhibits circulatory IL-6 and tumor necrosis factor- $\alpha$ (TNF- $\alpha$ ) and the transport of oxidized low-density lipoprotein (OxLDL) from the artery lumen to the subendothelial space; SP-D bound to CD305 (leukocyte-associated immunoglobulin-like receptor 1, LAIR1) reduces generation of reactive oxygen species (ROS) in foam cells (right and center in 1, and lower right in 5). SP-D bound to CD305 reduces ROS generation in circulating monocytes, and reduced ROS impedes oxidation of LDL (center in 1). Circulating native C-reactive protein (nCRP) bound to cellular or microparticle lysophosphatidylcholine (LPC) generated by phospholipase $\mathrm{A}_{2}(\mathrm{PLA})$, or to phosphorylcholine (PC) can be dissociated to monomeric CRP (mCRP) with intermediate formation of non-native CRP (nnCRP), and mCRP can bind lipid rafts and increase ROS formation (left in 1). [2] SP-D reduces T-cell proliferation and interferon- $\gamma$ (IFN- $\gamma$ ) and TNF- $\alpha$ release (top in 2). [3] [SP-D and SP-A facilitate intimal severe acute respiratory syndrome coronavirus-2 (SARS-CoV-2) virus removal by macrophages through CRT/CD91Rs (center in 3). SP-D binding to osteoclast-associated immunoglobulin-like receptor (OSCAR) in macrophages and foam cells enhances TNF- $\alpha$ release that stimulates SP-D production by smooth muscle (SMC) cells. SP-D also lowers SMC IL-8 (right in 3). [4] Pattern recognition proteins surfactant protein (SP)-A, SP-D, mannose binding lectin (MBL) and complement component 1q (C1q) facilitate macrophage uptake of apoptotic cells in atherosclerotic plaques through calreticulin (CRT)/CD91 receptors (Rs) (bottom in 4). [5] Immunoglobulin M (IgM) anti-oxidation-specific natural antibodies (OSE NAbs) in the arterial intima facilitate macrophage/foam cell uptake of apoptotic cells through Fc $\alpha / \mu R s$ (lower left in 5). Low-density lipoproteins (LDL) are taken by macrophages/foam cells through LDLRs (center in 5). Reduced foam cell ROS disallows LDL oxidation in the intima (lower left in 5). SP-D binding of CRT/CD91Rs leads to reduced inflammation characterized by reduced secretion of TNF- $\alpha$ in macrophages/foam cells; reduced nuclear factor $\mathrm{KB}(\mathrm{NF} \kappa \mathrm{B})$ activation and reduced macrophage recruitment and apoptosis; reduced expression of TNF- $\alpha$ receptor 1 (TNFR1) with concomitant reduction of foam cell TNF- $\alpha$ binding and reduced inducible nitric oxide synthase (iNOS), complement C1r protein, IL-6 and monocyte chemoattractant protein-1 (MCP-1) (upper left in 5). Native CRP (nCRP) facilitates clearance of oxidized/modified LDL through FcyRs and CD36 (upper right in 5); and IgM anti-OSE helps with clearance of oxidized/modified LDL through Fc $\alpha / \mu R s$ (upper right in 5), and by inhibiting their uptake through scavenger receptors lectin-like oxidized low-density lipoprotein (LDL) receptor-1 (LOX-1), scavenger receptor class B type 1 (SR-BI), scavenger receptor A1 (SR-A1) and CD36 (right in 5); all leading to reduced foam cell formation. 


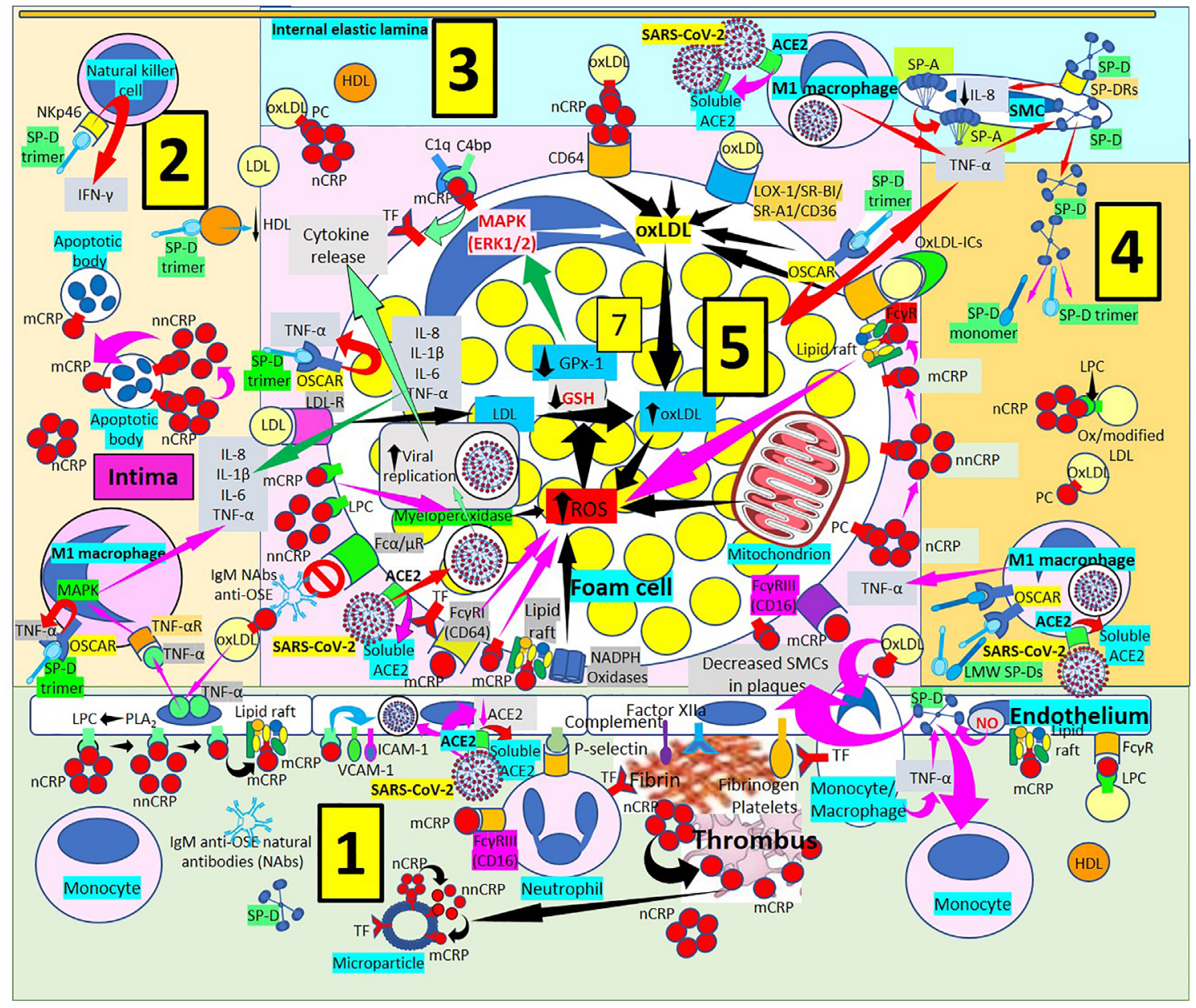

FIGURE 5 | Surfactant proteins in atherogenesis. [1] Monomeric C-reactive protein (mCRP) bound to Fcy receptors (Rs) and lipid rafts is proinflammatory and induces endothelial nitric oxide (NO) (right in 1). NO and monocyte/macrophage tumor necrosis factor- $\alpha$ (TNF- $\alpha$ ) increase surfactant protein D (SP-D). SP-D and oxidized LDL (oxLDL) attract monocytes into the intima and SP-D decreases smooth muscle cells (SMCs) in plaques (right in 1). Monocytes/macrophages express tissue factor (TF), and endothelial-bound procoagulants (factor Xlla, fibrinogen) and complement participate in fibrin and thrombus formation further generating mCRP and microparticles (center right in 1). Monomeric CRP via FcyRIII promotes neutrophil recruitment into the plaques via endothelial P-selectin (center in 1). Circulating native CRP (nCRP) bound to cellular lysophosphatidylcholine (LPC) generated by phospholipase A2 (PLA2) can be dissociated to mCRP with intermediate formation of non-native CRP (nnCRP); mCRP binds lipid rafts and cellular LPC and activate adhesion molecules intercellular adhesion molecule-1 (ICAM-1) and vascular cell adhesion molecule-1 (VCAM-1) (left in 1). Severe acute respiratory syndrome coronavirus-2 (SARS-CoV-2) can invade endothelial cells through angiotensin converting enzyme 2 (ACE2), release soluble ACE2 and reduce endothelial ACE2 (center left in 1). [2] OxLDL-induced endothelial TNF- $\alpha$ release stimulates TNF- $\alpha$ receptor (R)-mediated mitogen-activated protein kinase (MAPK) activation and proinflammatory cytokine release. SP-D trimers stimulate osteoclast-associated receptor (OSCAR)-mediated TNF- $\alpha$ release. Dissociation of $\mathrm{nCRP}$ to $\mathrm{mCRP}$ passing through nnCRP occurs in intimal apoptotic cells. SP-D trimers lower highdensity lipoproteins (HDL), and bind NKp46 to activate natural killer (NK) cells releasing interferon- $\gamma$ (IFN- $\gamma$ ). [3] Macrophages invaded by SARS-CoV-2 facilitate soluble ACE2 release that could neutralize more viruses. SP-D trimer OSCAR-mediated TNF- $\alpha$ release from foam cells (center right in 3 and upper right in 5) and macrophages stimulates SP-D synthesis and release from smooth muscle cells (SMCs) allowing further development of trimers and monomers under inflammation. SP-A is synthesized in SMCs and SP-D bound to SP-DRs lower IL-8 (right in 3). [4] Low molecular weight (LMW) SP-Ds (trimers, monomers) bind OSCAR in macrophages and release more TNF- $\alpha$ enhancing inflammation. [5] OxLDL uptake, increased ROS production and reduced antioxidant activity (glutathione peroxidase, GPx-1; glutathione, GSH) enhance foam cell formation (center in 5). SARS-CoV-2 can invade macrophages/foam cells through ACE2 and release soluble ACE2 (lower left in 5). Monomeric CRP through FcyRs and bound to phosphorylcholine (PC) and lipid rafts associated with nicotinamide adenine dinucleotide phosphate (NADPH) oxidases can increase reactive oxygen species (ROS) and TF (lower left and center lower left in 5). OxLDL bound to lgM natural antibodies (NAbs) can block Fc $\alpha / \mu$-mediated oxLDL uptake. CRP (most probably mCRP and/or nnCRP) can activate myeloperoxidase and generate ROS (lower left in 5). LDL is taken by LDL-Rs into the cell (center left in 5). LMW SP-Ds (trimers and/or monomers) bound to OSCAR can enhance TNF- $\alpha$ release, and foam cells also release further TNF- $\alpha$, interleukin (IL)-8, IL-1B and IL-6 contributing to inflammation (center left in 5). Complement component 1q (C1q) and C4b-binding protein (C4bp) compete for mCRP to adjust local complement activation/inhibition balance; mCRP enhances TF expression (upper left in 5). OxLDL is transported into foam cells through CD64 (bound to CRP); scavenger receptors lectin-like oxidized low-density lipoprotein (LDL) receptor-1 (LOX-1), scavenger receptor class B type 1 (SR-BI), scavenger receptor A1 (SR-A1) and CD36; and FcyRs (oxLDL immune complexes, oxLDL-ICs) (upper left, center and right in 5). Native CRP generates mCRP in foam cell membranes and lipid raft-bound mCRP enhances ROS (center right in 5). 
considered to be a sensitive biomarker of systemic inflammation, mainly produced by liver hepatocytes, secondary to cytokine stimulation (i.e., IL-6, IL-1 $\beta$ or TNF- $\alpha$ ) $(113-115)$ that increases 1,000-10,000-fold at sites of infection or inflammation within 2472 hours $(114,116-126)$, from the $0.8 \mathrm{mg} / \mathrm{L}$ found in healthy young adult individuals (119). CRP is also synthesized in extrahepatic cells and tissues including smooth muscle cells of atherosclerotic lesions with active disease, foam cells, macrophages, alveolar macrophages, epithelial cells of the respiratory tract, lymphocytes, monocytes, and endothelial cells, among others (127-135).

CRP binds and aggregates oxidized low-density lipoprotein (ox-LDL) and enhances macrophage oxLDL uptake, leading to mitogen-activated protein kinase activation (136) and foam cell formation (137). CRP binds to many ligands (118-120, 138141); phosphorylcholine (PC) being the most characterized, that starts damaged cell recognition and phagocytosis $(118,119,121)$ and is responsible for binding to microbial capsular polysaccharide, oxLDL and apoptotic cells, but not either native LDL or viable cells not exposing the PC moieties (118, $119,133,138,139)$. CRP amino acids $\mathrm{Phe}^{66}$ and Glu ${ }^{81}$ promote the binding of CRP to PC $(138,142,143)$, and the opposite face of native (n)CRP binds complement $\mathrm{Cq1}$ and $\mathrm{Fc} \gamma$ receptors, whose binding sites are overlapping $(119,138)$.

Pentameric nCRP, recognized as an antibody ancestor (144), is constituted by five identical monomers (homopentamer), known as nCRP. CRP can be identified in three different forms: 1) nCRP, 2) Non-native pentameric CRP (nnCRP), and 3) Monomeric CRP (mCRP) (118-126). Native nCRP can irreversibly dissociate at sites of inflammation/infection into five separate mCRP monomers, each containing 206 amino acids with a molecular mass of about $23 \mathrm{kDa}$ (118-123, 130, 133, 145-161). The different CRP isoforms may explain their protective and destructive effects, with nCRP being predominantly anti-inflammatory inducing Th2/M2 responses, while mCRP being mainly proinflammatory inducing Th1/M1 responses (146, 161-165). Pentameric nCRP bound to PC acts via membrane glycoprotein $\mathrm{F} c \gamma$ receptor (R) I to promote M2 macrophage differentiation dependent on IL-13 (146). Pentameric nCRP maintains an anti-inflammatory response by: a) Enhancing phagocytosis and apoptotic cell clearance, b) Protecting against cell lysis through factor $\mathrm{H}$ recruitment and preventing assembly of the complement membrane attack complex, c) Preventing cell damage by enhancing membrane-bound expression of complement regulators decay-accelerating factor, membrane cofactor protein, and CD59, d) inhibiting nitric oxide production, and e) Inducing mononuclear cell interleukin-1 receptor antagonist maintaining an anti-inflammatory cytokine profile $(119,161,166,167)$. All these effects require the presence of $\mathrm{Clq}$, indicating a pivotal role for the early complement component(s) in the anti-inflammatory effects of CRP (167) (Figure 6). Pentameric nCRP and CRP peptides 77-82, 174-185 and 201-206 can limit the inflammatory response resolving inflammation by reducing neutrophil endothelial adhesion and tissue migration $(159,162,168)$

Pentameric nCRP binds to Fc $\gamma$ RIIa (CD32) and Fc $\gamma$ RI (CD64) on polymorphonuclear leukocytes and monocytes/ macrophages although the major receptor for $\mathrm{nCRP}$ on phagocytic cells is FcyRIIa (169-178). Native nCRP binds FcoRI/CD89 on neutrophils and macrophages, and, in neutrophils, nCRP induces Fc $\alpha$ RI surface expression, phagocytosis and TNF- $\alpha$ secretion (179). The binding of nCRP to both stimulatory receptors, Fc $\gamma \mathrm{RI}$ and Fc $\gamma \mathrm{RIIa}$, increases phagocytosis and the release of inflammatory cytokines; and to the inhibitory receptor, Fc $\gamma$ RIIb, by blocking activating signals, allows nCRP to maintain an equilibrium leading to a predominant anti-inflammatory effect (114, 115). CRPenhanced opsonization of apoptotic cells and subsequent phagocytosis by macrophages, mediated through Fc $\gamma$ R-CRPbinding, impedes inflammation caused by necrotic and apoptotic cells (180) (Figures 6, 7).

Monomeric mCRP is considered to be proinflammatory because a) Stimulates leukocyte chemotaxis and recruitment to areas of inflammation, b) delays apoptosis; c) Increases interleukin8 and monocyte chemoattractant protein-1 production; and d) Induces nitric oxide production $(161,181)$. Ligand-bound nCRP can dissociate into mCRP which modulates complement-mediated inflammation and activates neutrophils and monocytes (133). When mCRP is in a fluid phase, in ligand-free state, inhibits C1q binding to other complement activators; but when mCRP is immobilized on the cell surface either alone or bound to ox-LDL or enzyme-modified (E)-LDL, it binds and activates complement $\mathrm{C} 1 \mathrm{q}$, leading to the turnover of $\mathrm{C} 3$, to a great extent bypassing the more inflammatory and destructive terminal sequence by recruitment of Factor H (157) (Figures 6, 7).

The mCRP pro-inflammatory effects suggest that MCRP is proatherogenic. Indeed, $\mathrm{mCRP}$, but not nCRP, a) Induces reactive oxygen species monocyte/macrophage production and facilitates macrophage uptake of necrotic cells (158); and b) Causes neutrophil activation, firm cell adhesion $(159,162)$ and repression of neutrophil apoptosis, facilitating neutrophil survival, and amplifying the acute inflammatory response; both contributing to atherosclerotic plaque formation and plaque rupture or destabilization $(150,152)$. Dissociation of nCRP on activated cell membranes occurs via phospholipase A2-mediated lysophosphatidylcholine generation $(149,150)$ (Figure 7). The mCRP isoform uses the low-affinity immune complex binding immunoglobulin $\mathrm{G}$ (IgG) receptor FcyRIIIb (CD16b) on neutrophils and the FcyRIIIa (CD16a) on monocytes (161). The link of mCRP with FcyRIII (CD16) in human neutrophils and endothelial cells $(177,178,182-184)$, other receptors of the Fc $\gamma R$ family (185), integrins $\alpha v \beta 3$ and $\alpha 4 \beta 1$ (186), fibronectin, vitronectin, as well as lipid rafts microdomains on cell membranes are essential for mCRP-mediated cellular signaling and its proinflammatory effects (187). Monomeric mCRP promotes: 1) Increased arterial endothelial monocyte chemoattractant protein-1 and interleukin-8 (IL-8) production and enhanced intercellular adhesion molecule-1, E-selectin, and vascular adhesion molecule-1 expression (184); and 2) Increased IL-8 production by human neutrophils through peroxynitrite $\left(\mathrm{ONOO}^{-}\right)$-mediated activation of nuclear factor- $\mathrm{\kappa B}$ and activator protein 1 (183).

Non-native CRP (nnCRP) generated during membranebound nCRP dissociation (187) into subunits retaining some of 


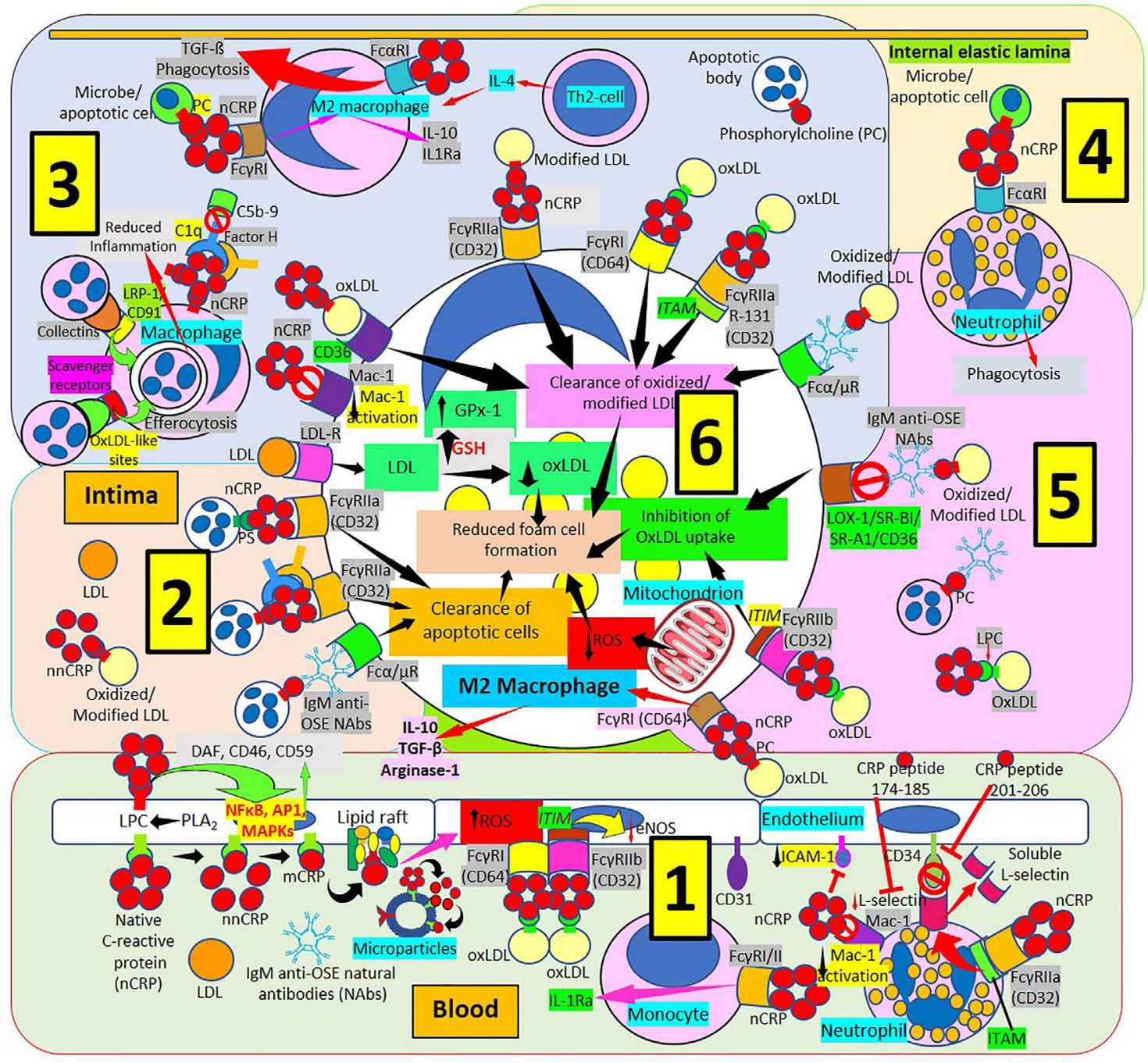

FIGURE 6 | C-reactive protein innate immunoprotective responses in atherosclerotic lesions. [1] Native pentameric C-reactive protein (nCRP) and CRP peptides prevent neutrophil adhesion by downregulating L-selectin expression through activation of Fcy receptor (R) Ila and immunoreceptor tyrosine-based activation motif (ITAM), and by inducing L-selectin shedding; nCRP downregulates CD11b/CD18 (Mac-1) receptor activation and endothelial intercellular adhesion molecule-1 (ICAM1) expression (right in 1). Native pentameric CRP induces FcyR-mediated interleukin (IL)-1 receptor antagonist (Ra) expression in mononuclear cells (middle in 1). CRP bound to oxLDL can reduce endothelial nitric oxide synthase (eNOS) through FcyRs and immunoreceptor tyrosine-based inhibitory motif (ITIM) activation (middle in 1). Circulating nCRP bound to cellular or microparticle lysophosphatidylcholine (LPC) generated by phospholipase $A_{2}\left(P L A_{2}\right)$, or to phosphorylcholine (PC) can be dissociated to monomeric CRP (mCRP) with intermediate formation of non-native CRP (nnCRP), and mCRP can bind lipid rafts and increase reactive oxygen species (ROS) formation (left in 1). Native CRP can prevent cell damage by enhancing membrane-bound expression of complement regulators decay-accelerating factor (DAF), membrane cofactor protein (CD46) and CD59 mediated by transcription factor (nuclear factor kappa B, NFkB; activator protein 1, AP-1; mitogenactivated protein kinases, MAPKs) activation. [2] The clearance of apoptotic cells is facilitated by immunoglobulin M anti-oxidation specific epitopes natural antibodies (IgM anti-OSE NAbs) and Fc $\alpha / \mu R s ; n$ nCRP-PC, complement 1q (C1q), factor H and FcyRlla; and nCRP-phosphatidylserine (PS) and FcyRlla, respectively. Lowdensity lipoproteins (LDL) uptake occurs via LDL-Rs. [3] Native CRP downregulates Mac-1 activation. Native CRP, C1q and factor H; collectins bound to low density lipoprotein receptor-related protein (LRP)-1/CD91; and oxLDL-like sites bound to scavenger receptors facilitate efferocytosis. CRP bound to PC and FcyRl induces M2 macrophage differentiation that reduces inflammation through IL-10 and IL-1R antagonist (IL1Ra) secretion. Th2 T-lymphocytes release IL-4 further inducing M2 macrophages. CRP binds Fc $\alpha R I$ facilitating transforming growth factor- $\beta$ (TGF- $B$ ) release and phagocytosis. Fc $\gamma R$ R CD32 and CD64, scavenger receptor CD36, FcyRlla R131 and Fc $\alpha / \mu R$ facilitate clearance of oxidized/modified LDL. [4] FcoRI mediates nCRP neutrophil stimulation of phagocytosis. [5] Immunoglobulin M (IgM) anti oxidation-specific epitopes (OSE) blocks scavenger receptors lectin-like oxidized low-density lipoprotein (LDL) receptor-1 (LOX-1), scavenger receptor class B type 1 (SR-BI), scavenger receptor A1 (SR-A1) and CD36 inhibiting oxLDL uptake. Native CRP through CD32 and immunoreceptor tyrosine-based inhibitory motif (ITIM) inhibits oxLDL uptake; and through CD64 binding induces M2 macrophage differentiation that enhances release of IL-10, TGF- $\beta$ and arginase 1. [6] Clearance of oxidized/modified LDL, inhibition of oxLDL uptake, clearance of apoptotic cells, reduced reactive oxygen species (ROS) and reduced oxLDL formation associated with increased glutathione (GSH) and glutathione peroxidase-1 (GPx-1) activity contribute to reduced foam cell formation. 


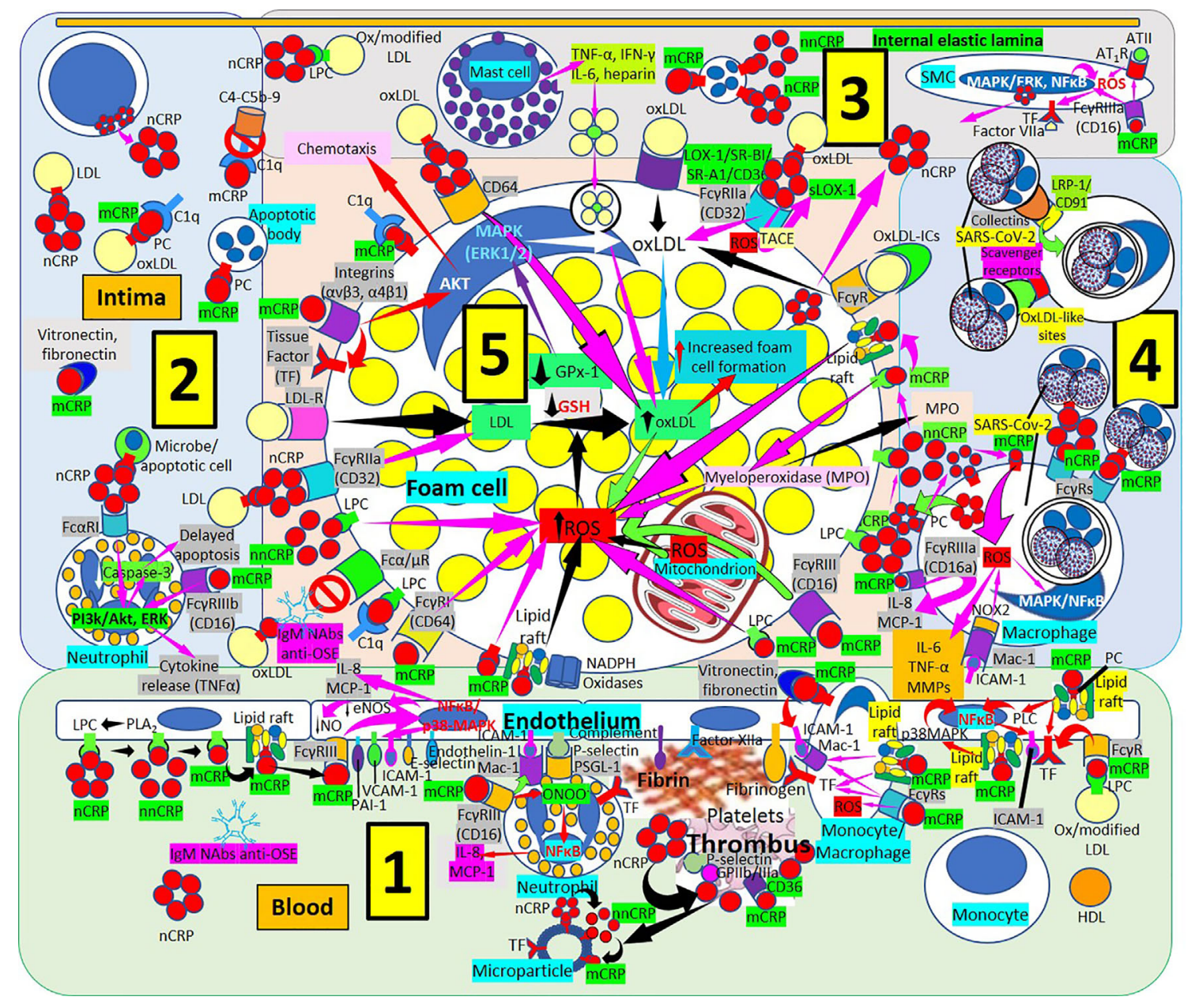

FIGURE 7 | Monomeric C-reactive protein in atherogenesis. [1] From right to left. Monomeric C-reactive protein (mCRP) bound to oxidized/modified (ox/modified) low density lipoprotein (LDL) through lysophosphatidylcholine (LPC) binds Fcy receptors (Rs) upregulates endothelial tissue factor (TF) (right in 1). Monomeric CRP bound to phosphorylcholine (PC) in lipid rafts activate intracellular signaling cascades (phospholipase C, PLC; p38 mitogen activating protein kinases, MAPK; nuclear factor $\mathrm{KB}, \mathrm{NF \kappa B}$ ) enhancing endothelial intercellular adhesion molecule-1 (ICAM-1) (right in 1). Monocytes/macrophages adhere to endothelium following mCRPmediated ICAM-1 and CD11b/CD18 (Mac-1) receptor upregulation; mCRP in monocytes/macrophages upregulate TF and Mac-1 and adhere to vitronectin/ fibronectin in the intima (right in 1). TF, factor Xlla, fibrinogen and complement participate in thrombus formation and platelets generate further mCRP from nCRP. Interaction among mCRP, glycoprotein (Gp) Ilb/llla, P-selectin and CD36 participate in inflammation and thrombus formation. Endothelial and platelet microparticles generate mCRP from $\mathrm{nCRP}$ and nonnative CRP (nnCRP) (center right in 1). Monomeric CRP facilitates endothelial neutrophil adherence via FcyRIII and Mac-1 upregulation; neutrophil Mac-1 and P-selectin glycoprotein ligand (PSGL)-1 attach to ICAM-1 and P-selectin, respectively; mCRP- FcyRIII enhance peroxinitrite (ONOO) generation, NFKB activation and IL-8 and monocyte chemoattractant protein-1 (MCP-1) release (center in 1). Endothelial phospholipase $\mathrm{A}_{2}\left(\mathrm{PLA} \mathrm{A}_{2}\right)$ generates LPC facilitating monomerization of CRP that binds lipid rafts and FcyRlll and activates NFKB/p38MAPK, upregulating plasminogen activator inhibitor (PAI)-1, vascular cell adhesion molecule (VCAM)-1, E-selectin and endothelin-1; downregulating endothelial nitric oxide synthase (eNOS) and nitric oxide (NO); and enhancing IL-8 and MCP-1 release (left and center left in 1). [2] CRP via FcoRI and mCRP via FcyRlllb can activate phosphatidylinositol 3-kinases/protein kinase B and extracellular signal-regulated kinases (PIJK/AKT, ERK) signaling pathways in intimal neutrophils and enhance tumor necrosis factor- $\alpha$ (TNF- $\alpha$ ) release and delay apoptosis. T-cells can produce CRP enhancing intimal CRP. [3] Mast cells contribute to oxLDL macrophage uptake through TNF- $\alpha$, interferon- $\gamma$ (IFN- $\gamma$ ), IL-6 and heparin secretion. CRP can be synthesized by smooth muscle cells (SMC) and foam cells, and FcyRIlla-bound mCRP in SMCs induce ROS and upregulate TF enhancing thrombus formation through factor VII activation; mCRP can upregulate angiotensin (AT), R and ATII-mediated ROS production. [4] LRP-1/CD91 and scavenger receptors facilitate collectin- and oxLDL-like site-mediated severe acute respiratory syndrome coronavirus-2 (SARS-CoV-2) uptake, respectively, and FcyRs can facilitate nCRP and mCRP-mediated SARS-CoV-2 macrophage phagocytosis; mCRP and ICAM-1 can mediate ROS formation and subsequent release of IL-8, MCP-1, IL-6, TNF- $\alpha$ and matrix metalloproteinases (MMPs). [5] Increased ROS formation, reduced glutathione (GSH) and glutathione peroxidase (GPx)-1 activity increase foam cell formation sustaining inflammation in the plaque (center in 5). OxLDL bound to IgM natural antibodies (NAbs) can block Fco/ $/$-mediated oxLDL uptake. Monomeric CRP bound to lipid rafts, LPC, PC or FcyRs and LPC-bound nonnative CRP (nnCRP) could enhance ROS formation; and LPC bound mCRP activate C1q (lower left in 5). CRP/CD32 and LDL-R facilitate macrophage LDL uptake (center left in 5). CRP bound to CD64 enhance oxLDL uptake and foam cell formation; mCRP contributes to intimal inflammation, integrin-mediated TF upregulation and chemotaxis and C1q activation (upper left in 5). Scavenger receptors lectin-like oxidized low-density lipoprotein (LDL) receptor-1 (LOX-1), scavenger receptor class B type 1 (SR-BI), scavenger receptor A1 (SR-A1), and CD36,facilitate oxLDL macrophage uptake; and FcyRs CRP-bound oxLDL and oxLDL immune complexes (oxLDL-ICs) (upper center and upper right in 5). LPC membrane-bound nCRP dissociates into mCRP with intermediate nnCRP formation, and MCRP can induce myeloperoxidase (MPO) synthesis and release; LPC- and lipid raft-bound mCRP can enhance ROS formation (right in 5). Monomeric CRP bound to CD16 or LPC can enhance foam cell ROS (right in 5). 
the native conformation before fully dissociating into mCRP, seems to be, as mCRP, proinflammatory, allowing more effective CRP function regulation, and enhancing activation of the classical complement pathway (160, 161, 181). Pentameric nnCRP could also be atheroprotective since nCRP and nnCRP bind atherogenic LDL and reduce foam cell formation and atherogenic LDL-associated inflammation (188, 189). Pentameric nnCRP has a more relaxed structure when compared to nCRP, exposing neoepitopes indispensable for both immune and complement activation. The dissociation/ relaxation of nCRP into nnCRP occurs on necrotic, apoptotic, and ischemic cells, membranes of activated platelets, monocytes, and endothelial cells, and on the surface of microparticles, via PC binding. Pentameric nCRP does not possess intrinsic proinflammatory properties, while nnCRP and mCRP do (181). Both nnCRP and mCRP can activate platelets, leukocytes, endothelial cells, and complement (181). Pentameric nnCRP seems the dominant proinflammatory isoform (181), and by exposing amino acids 199-206, shows mCRP-like antigenicity being recognized by antibodies to $\mathrm{mCRP}$, and enhances complement fixation (190). Furthermore, a form of CRP, most probably mCRP, enhances vascular smooth muscle cell tissue factor expression via p44/42 mitogen-activated protein kinase and increased production of reactive oxygen species, promoting thrombosis in atherosclerotic plaques $(191,192)$. Interactions of mCRP with fibronectin (193), vitronectin, and other proteins, could be part of an available system to eliminate excess mCRP and/or scavenge altered, damaged and denatured proteins limiting inflammation in the arterial wall (120).

The interaction between mCRP, but not nCRP, and fibronectin occurs in residues 35-47 of mCRP that becomes exposed after nCRP dissociation. Monomeric mCRP can enhance monocyte fibronectin adhesion and upregulate endothelial cell adhesion molecule expression (Figure 7). Two major Fc $\gamma$ Rs, Fc $\gamma$-RI (CD64), and Fc $\gamma$-RIII (CD16) were identified as the major $\mathrm{Fc} \gamma \mathrm{Rs}$ on human monocytes to promote inflammation independently of lipid raft signaling. Enriched lipid raft microdomains are the major surface sensors for mCRP on the apical membranes of endothelial cells (149). Endothelial cell apical mCRP being present in circulation for an extended period of time as a consequence of endothelial damage, enhanced conversion from nCRP on microparticles or activated platelets which can facilitate endothelial cell activation through phospholipase $\mathrm{C}, \mathrm{p} 38$ and nuclear factor- $\mathrm{\kappa B}$ signaling pathway induction, contribute to $\mathrm{mCRP}$-mediated chronic vascular inflammation. Phospholipase A2-mediated lysophosphatidylcholine generation in endothelial cell apical membranes could enable nCRP dissociation in circulating inflammatory cells generating $\mathrm{mCRP}$ and triggering leukocyteendothelium interaction further enhancing inflammation (149, 150). The mCRP isoform, unlike nCRP, has a stimulatory effect on platelets, facilitates thrombus growth through platelet stimulation, and is the more potent reagent, both increasing monocyte activation and production of reactive oxygen species, which could be generated through myeloperoxidase-mediated respiratory burst and raft-associated reduced nicotinamide adenine dinucleotide phosphate (NADPH)-oxidase during oxLDL-mediated foam cell formation (194). Thrombus formation and the subsequent activation of the coagulation cascade with final generation of fibrin is facilitated by the mCRP-mediated enhancement of tissue factor on the endothelial cell surface, platelet aggregation and thrombus growth $(153,154)$. CRP seems to play a major role in inflammation and host responses to infection by its effects on the complement pathway, apoptosis, phagocytosis, nitric oxide release, release of proatherosclerotic factors like soluble lectinlike oxidized low-density lipoprotein receptor-1 $(195,196)$ and production of cytokines, particularly interleukin- 6 and tumor necrosis factor- $\alpha$.

\section{C-Reactive Protein, Coronaviruses and SARS-CoV-2}

Increased CRP levels have been described in patients infected with the most virulent types of influenza A virus, and the outcome of human influenza disease has been related to increased CRP production, with the highest levels of CRP corresponding to the more severe symptoms including mortality (197-201). Similarly, high levels of CRP were found in patients with severe COVID-19 disease showing increased organ damage, worse outcome, and increased mortality (202206). The hyperinflammation associated with COVID-19 infection in children and adults (207-210) affects all organs and tissues including atherosclerotic lesions (Figure 7) and is always associated with very high levels of CRP, that enhance and amplify the inflammatory and prothrombotic microenvironment, most certainly mediated by increased generation of mCRP, which could also contribute to plaque instability through the demonstrated CRP-induced expression of matrix metalloproteinases 1,2 , and 9 (154). Considering the pathophysiology of COVID-19 infection and its complications, it is appealing to propose that membrane-associated monomeric CRP isoform may play a role, particularly promoting proinflammatory and procoagulant effects $(205,206)$. Viruses utilize host cells to reproduce and viral infections eventually result in cell death, caused by cell's surface membrane alterations, apoptosis, and cell lysis $(211,212)$. Therefore, the enhancement of apoptosis-dependent phagocytosis of virus-infected cells is a fundamental approach to eliminate the virus without increasing inflammation, since apoptosis is considered a silent mode of cell death (213). CRP, in the presence of calcium, binds to phosphorylcholine (PC) residues present in pneumococcal Cpolysaccharide of streptococcus pneumoniae and PC exposed on damaged and apoptotic cells $(138,139)$. CRP can block the attachment of bacteria expressing cell-surface PC to host cells (214), and at the same time facilitate complement-mediated bacteriolysis and complement/factor $\mathrm{H}$-mediated macrophage phagocytosis. The proinflammatory effects of $\mathrm{mCRP}$ in the alveoli may be inhibited by PC in lung surfactant, which is abundant in the terminal airway where the major lipid component is dipalmitoyl phosphatidylcholine that has a polar head group consisting of PC (214). The collectins, surfactant proteins $\mathrm{A}$ and $\mathrm{D}$, enhance the antimicrobial activity of alveolar 
macrophages (214), and the phospholipid component of surfactant has both immune-enhancing and inhibitory effects $(214,215)$. The CRP provided by the increased plasma levels secondary to elevated CRP hepatocyte synthesis and the local production by epithelial cells of the human respiratory tract (132) can facilitate the antimicrobial activity of bacteria complicating any RNA coronavirus infection such as COVID19. This occurs specifically by targeting organisms that express cell-surface PC; since nCRP can bind the bacterial PC moieties and inhibit the platelet activating factor receptor-mediated microbe epithelial cell adherence and invasion (214). Since the concentration of the phospholipid component of surfactant is estimated to be $5 \mathrm{mg} / \mathrm{ml}$, surfactant may not always have a protective function, but may inactivate the innate CRP-mediated defense allowing PC-expressing bacteria to adhere to and invade alveolar epithelial cells (214). The highly elevated CRP levels during infection and inflammation especially in association with hyperinflammation during coronavirus infection, may facilitate the neutralization of bacterial PC impeding attachment and invasion of alveolar epithelial cells. The marked elevation of CRP levels during the hyperinflammation found in severe cases of COVID-19 infection, however, typically has a detrimental outcome. The explanation may relate to the concomitant generation of increased amounts of mCRP.

\section{IGM PATTERN RECOGNITION PROTEIN, INNATE IMMUNE RESPONSES AND THE CORONAVIRUS}

Immunoglobulin M (IgM) antibodies, first identified in the 1930s as high molecular weight antibodies (216-218), account for the major integrant of the natural antibodies and is also the first antibody type produced during a primary antibody response (219). IgM was identified immediately following the discovery of CRP, another major component of innate immunity (113). IgM is the first responder to foreign invaders including the viruses that have caused major pandemics, such as the current COVID19 virus. IgM, considered an ancient antiviral weapon, exists in all vertebrates (220). Its monomeric form (Figure 8) is expressed on B cells as the B-cell antigen receptor (220). IgM is secreted mainly as a pentameric molecule (Figure 8) (220, 221) containing a joining chain ( $\mathrm{J}$ chain), and in humans has a high serum concentration $(1.5 \mathrm{mg} / \mathrm{ml})$.

Following the initial characterization of the IgM antibody (219), much is now known regarding its structure, production, and function. It is globally recognized that IgM provides a first line of defense during microbial infections, before a high affinity IgG adaptive immune response develops imparting lasting immunity and immunological memory. Detection of an IgM immune response is recognized as a measure of being exposed to infectious pathogens, however, the role of IgM antibodies in many microbial infections has not been clearly identified. Several studies showed that IgM natural antibodies produced innately without previous antigen exposure, or IgM antibodies produced in response to antigen exposure, play an important and possibly unvalued role in many microbial infections, as well as in the noninflammatory clearance of apoptotic cells (222). IgM- and complement-mediated opsonization of apoptotic cells allows fast absorption by macrophages. If this process does not occur, cells become necrotic inducing inflammation (223). Although the cellular origins of natural (innate) and immune (adaptive) IgM are different, only minimal differences in the molecular characteristics between natural and immune IgM are identified (224). Natural IgM has low affinity and high avidity (polyreactivity) and plays a paramount role in primary host defense, since it contains more flexible constitutive antigenbinding sites that enhance interactions with numerous antigens, including viruses and bacteria $(224,225)$. Much of the circulating natural IgM is secreted by B-1 cells, a distinct Bcell lineage that develops early during ontogeny (226). In addition, a better understanding of the production and host defense involvement of $\operatorname{IgM}$ has been clarified through the identification of the different roles of B-1a and B-1b cells. IgM plays a fundamental role in both, early immunity as well as longterm protection, against numerous microbial pathogens. The demonstrated generation of lasting IgM responses in vivo suggest that IgM production can be targeted as part of vaccination strategies $(220,224)$.

The pentameric structure of IgM that provides a high valency to the molecule, and the low affinity of IgM polyreactive natural antibodies, both favor agglutination (100-10,000 times more effective than $\operatorname{IgG}$ ), which is considered as a paramount component of the IgM-mediated virus neutralization. The high valency makes pentameric IgM a more efficient immunoglobulin in the binding and removal of viral particles and other pathogens, as well as apoptotic cells (227). Most of IgM molecules are polyreactive, being fundamental components of the IgM natural antibodies, that bind with low affinity to an ample variety of different structurally non-related antigens including bacteria and viruses to which the host was never exposed (228). Polyreactive IgM monomers on B cells bind repetitive antigenic determinants on bacteria and viruses and induce natural antibody production without the involvement of T-cells. T-cell-independent type 2 antigens are identified as very repetitive structures, that include cell membrane polysaccharides and bacterial flagella, that can crosslink B cell receptors to induce an IgM response (224).

There are two classes of IgM, natural (or innate) IgM, produced by innate-like B-1 cells without previous exposure to any antigen or pathogen; and immune (or adaptive) IgM, produced by both innate-like B-1 and adaptive B-2 cells following exposure to an antigen or pathogen (Figure 9) (224). B-1 cells, an innate-like B cell population responsible for natural antibody production and fast immune responses, are differentiated in B-1a and B-1b based on their expression or lack of expression of CD5, respectively (229). B1 cells in humans are present in the umbilical cord and in adult peripheral blood and express the novel $\mathrm{CD} 20^{+} \mathrm{CD} 27^{+} \mathrm{CD} 43^{+} \mathrm{CD} 70^{-}$phenotype (230-232). Although natural and immune IgM are produced by different types of cells, both molecules show negligible 
A

\begin{tabular}{|l|l|l|l|l|}
\hline $\mathrm{VL}$ & \multicolumn{2}{|c|}{$\mathrm{CN} / \mathrm{K}$} \\
\hline $\mathrm{VH}$ & $\mathrm{C} \mu 1$ & $\mathrm{C} \mu 2$ & $\mathrm{C} \mu 3$ & $\mathrm{C} \mu 4$ \\
\hline $\mathrm{VH}$ & ${ }^{\circ} \mathrm{C} \mu 1$ & $\mathrm{C} \mu 2$ & $\mathrm{C} \mu 3$ & $\mathrm{C} \mu 4$ \\
\hline $\mathrm{VL}$ & $\mathrm{CN} / \mathrm{K}$ \\
\hline
\end{tabular}

B

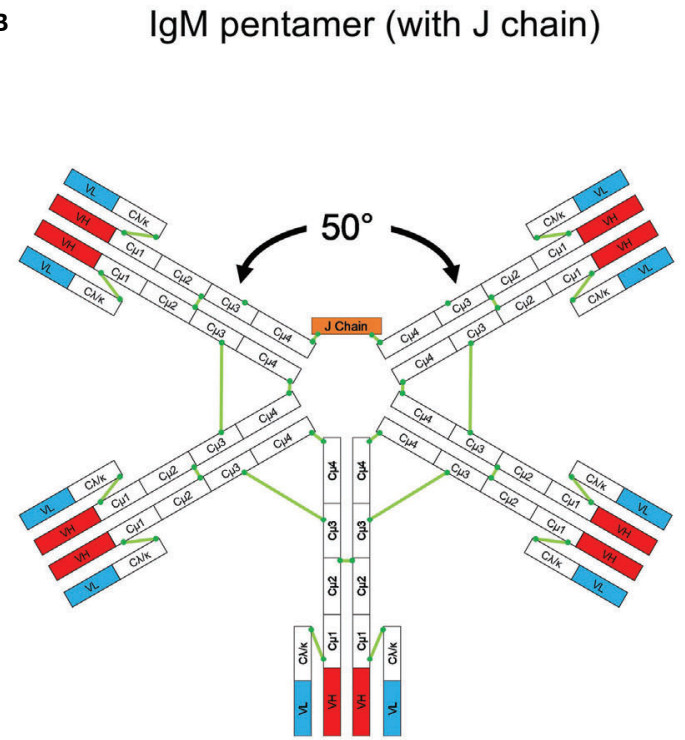

- cysteine

disulfide bond

c

IgM hexamer

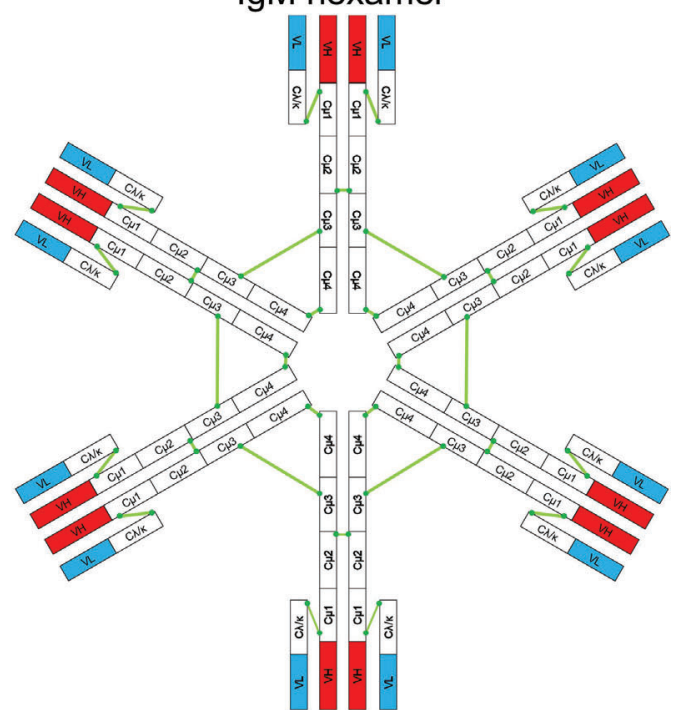

FIGURE 8 | Schematic structure of IgM. (A) Monomeric IgM is composed of two heavy $(\mu)$ and two light $(\lambda / \kappa)$ chains. Each heavy or light chain contains one variable region $(\mathrm{VH}$ or $\mathrm{VL}$ ) and one constant region ( $\mathrm{C} \mu 1-4$ and $\mathrm{C} / \mathrm{k})$. (B) Pentameric IgM contains five monomers and one $\mathrm{J}$ chain; disulfide bonds between each monomer form the pentamer; the structure shown in (B) is based upon the recent electron microscopy image presented by Hiramoto et al. (221). There is a $50^{\circ}$ gap where the $\mathrm{J}$ chain resides. (C) The IgM hexamer contains six monomers and resembles a hexagon. The $\mathrm{J}$ chain is generally absent in hexamers. With permission from Gong and Ruprecht, (220).

differences in their molecular properties. Natural IgM contains more versatile antigen-binding sites able to facilitate ample interactions with numerous antigens (224). Natural IgM has been identified in humans and mice and comprises the majority of total circulating IgM (224). Natural IgM can bind to numerous microbial pathogens $(224,225)$. B-1a cells are critical in early protection during influenza infections through their IL-17Adriven differentiation into high-rate natural IgM producing plasma cells (233) (Figure 9). Interestingly, deficiency of IL$17 \mathrm{~A}$ causes a severe reduction of B1a-derived natural antibody production in the respiratory tract what results in a profound alteration in the clearance of viral particles (233). Adaptive IgM adds to the humoral memory and long-term protection against infectious agents. Vaccination could potentially provoke longterm protective IgM responses (220). Innate and acquired humoral immune responses to viruses like the influenza virus are functionally recognizable immune responses (234).

Three $\mathrm{Fc}$ receptors (Rs) for IgM, that include $\mathrm{Fc} \alpha / \mu \mathrm{R}$, polymeric immunoglobulin receptor (pIgR), and $\mathrm{F} c \mu \mathrm{R}$ have been described (223). Interaction of IgM with pIgR results in secretory IgM formation in epithelial mucosal surfaces like intestine and lung. The $\mathrm{Fc} \alpha / \mu \mathrm{R}$ is able to bind $\operatorname{IgM}$ and $\operatorname{IgA}$, and it is expressed on lymphocytes, follicular dendritic cells, and macrophages. The Fc $\mu$ R binds only IgM and it is expressed on T and $\mathrm{B}$ lymphocytes.

IgM plays a more relevant, albeit underappreciated, role against microbial infections. IgM is very effective in the prevention and in the elimination of diverse types of microbial infections because of its unique properties (Figure 10). Therefore, the use of IgM to prevent and treat infections via immunization and/or passive antibody administration (220) has a paramount potential. It is at present very clear that a fundamental source of both natural and immune IgM comes from specialized B-1 cell subsets, but still much needs to be known regarding the origins, development, and maintenance of B-1 cell responses $(225,226,229,235)$. The knowledge obtained from research performed on B-1 responses should help in the development of vaccines designed to promote effective long-lived IgM immunity in order to prevent SARS-CoV-2 infection, improve 


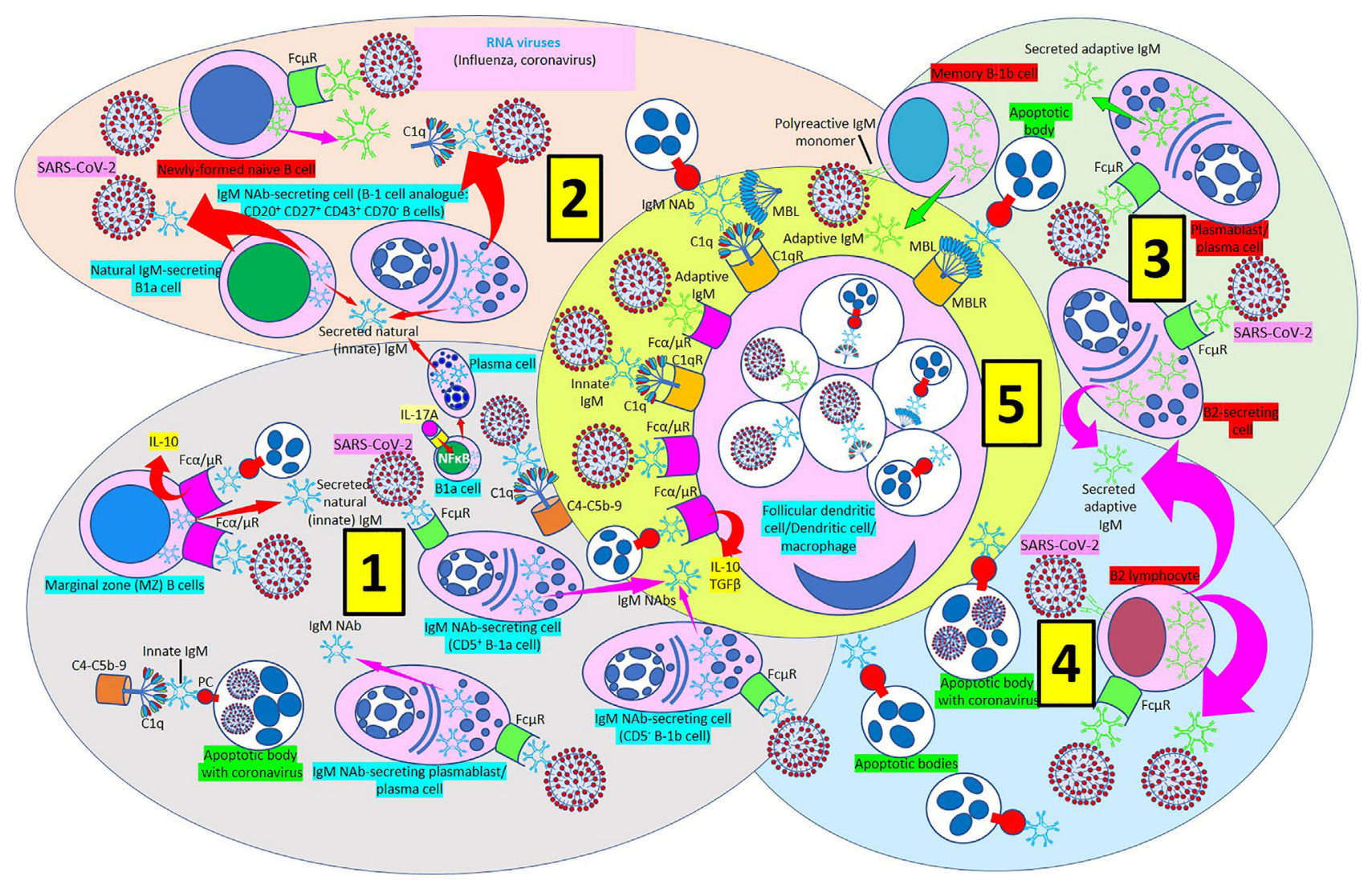

FIGURE 9 | IgM-mediated immune response in coronavirus infection. [1] Most of natural (innate) immunoglobulin M (lgM) natural antibodies (NAbs) are secreted by B-1 cells (CD5 ${ }^{+}$B-1a and CD5 $\left.-\mathrm{B} 1 \mathrm{~b}\right)$ without previous exposure to any antigen or pathogen. B-1a cells are critical in early protection during influenza infections through their IL-17A-driven differentiation into high-rate natural IgM producing plasma cells. Marginal zone (MZ) B cells can recognize IgM NAbs bound to RNA viruses and apoptotic cells through Fco/ $\mu$ receptors (Rs) and enhance interleukin-10 (IL-10) release. Innate IgM Nab-secreting cells (CD5 ${ }^{+}$B-1a and CD5 ${ }^{-}$B1b cells; plasmablasts/plasma cells) recognize virus-bound IgM NAbs through membrane Fc $\mu$ Rs. Innate IgM NAbs facilitate lysis of viruses and virus-infected apoptotic cells through activation of the complement cascade (C1q-C5b-9). [2] Natural IgM-secreting B1a cells and human B1 cells, identified in the umbilical cord and in adult peripheral blood and expressing the novel $\mathrm{CD} 2 \mathrm{O}^{+} \mathrm{CD} 27^{+} \mathrm{CD} 43^{+} \mathrm{CD} 70^{-}$phenotype contribute to natural (innate) IgM secretion. Polyreactive IgM monomers on $\mathrm{B}$ cells (newly formed naïve B-cells, memory B1b cells) bind repetitive antigenic determinants on bacteria and viruses and induce immune (adaptive) antibody production without the involvement of T-cells. [3] Immune (adaptive) IgM are produced by adaptive B2 cells following exposure to an antigen or pathogen. B2-secreting cells and plasmablasts/plasma cells can produce immune lgM following antibody recognition by FchRs. [4] B2 lymphocytes can secrete adaptive IgM antibodies following virus recognition by membrane lgM monomers and Fc $\mathrm{R}$ recognition of virus bound lgM. [5] Follicular dendritic cells, dendritic cells and macrophages can

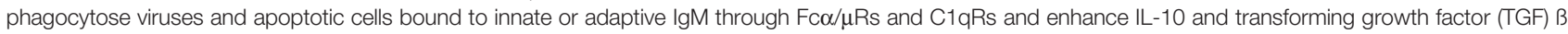
release to reduce inflammation.

COVID-19 disease outcome and reduce disease severity and mortality.

Each multi-cellular organism, including humans, is permanently exposed to infectious agents and transformed cells during its life cycle. Neither development nor life would be possible without an early recognition and a rapid elimination system (236). IgM NAbs behave as the ideal molecules to rapidly neutralize and remove viruses and bacteria, making them very useful molecules in the microbial innate immune responses (224). IgM has a molecular weight of $950 \mathrm{kDa}$ (pentameric IgM) (237), as previously mentioned it has a high blood concentration $(1.5 \mathrm{mg} / \mathrm{ml})(224,237,238)$, it is the first antibody triggered by an immune response after immunization or infection, and it has a serum half-life of 5 days in humans
(237). IgM is generated from germline configured transcripts in $B$ cells, has low affinity, and its high valency and ability to cause agglutination or clamping facilitates the neutralization and removal of viral particles. Due to the low affinity and high valency, the greatest number of IgM antibodies are polyreactive allowing them to bind to a wide range of phylogenetically conserved unrelated antigens present in viruses and bacteria (224).

It is generally thought that adaptive $\operatorname{IgM}$ does not play a significant role in long-term humoral immunity, however the identification of long-lived IgM plasma cells suggests that adaptive IgM may be an overlooked participant in humoral immunity against viral infections (220). The long-lasting contribution of IgM immune responses is supported by the 


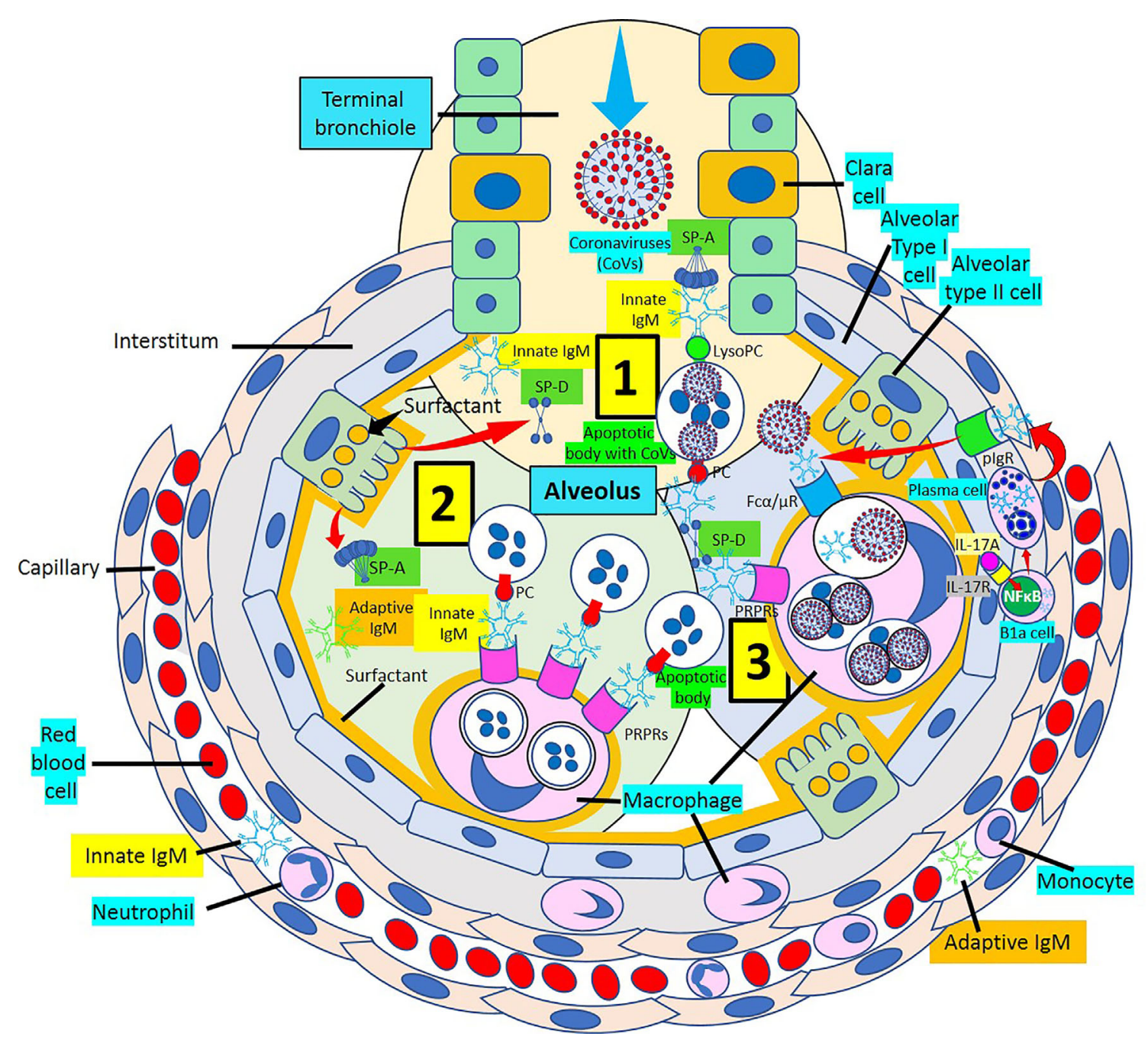

FIGURE 10 | Alveolus showing IgM response to coronavirus infection. [1] The arrival of coronaviruses into the alveolus generates an immediate lgM response mediated by innate and adaptive IgM antibodies. The IgM response in association with surfactant proteins D and A (SP-D and SP-A) facilitate virus neutralization and virus-infected apoptotic cell removal. [2] Innate and adaptive IgM participate in the macrophage-mediated removal of alveolar apoptotic cells through pattern recognition protein receptors (PRPRs) avoiding inflammation. [3] Virus-infected apoptotic cells are phagocytosed with the help of SP-D and SP-A through PRPRs. Recruitment of B1a cells into the alveolar wall under the stimulation of interleukin (IL)-17A via IL-17 receptor (IL-17R) and nuclear factor (NF) $\mathrm{kB}$ activation generate plasma cells that release lgM into the wall that is transported to the alveolus via polymeric immunoglobulin receptors (plgRs). Viral particles bind lgM and are phagocytosed via Fc $\alpha / \mu$ receptors (Fc $\alpha / \mu R s)$. lysoPC, lysophosphatidylcholine.

demonstration that IgM immunity is not impaired and is functionally intact in the elderly (239), and perhaps due to long-lived B cells, IgM responses can be maintained for long periods of time following infection or immunization (224).

As previously mentioned, $\operatorname{IgM}$ antibodies are divided into natural (innate), and immune (adaptive) IgM. Natural IgM is produced by innate-like B-1 cells in the absence of previous antigen stimulation, and immune IgM is produced by both innate-like B- 1 and adaptive B-2 cells after antigen stimulation. The demonstration that elevated SARS-CoV-2 specific IgM levels associate with poor outcome in patients with COVID-19 pneumonia becoming a prognostic factor for poor outcome is intriguing, and perhaps could be explained by the presence of high antibody levels indicating high viral load in these patients (240). IgM is $100-10,000$ times more effective than IgG in mediating agglutination, a fundamental part of the process of IgM-mediated virus neutralization (224). The recent demonstration that intranasal administration of an engineered IgM can improve efficacy, reduce resistance and simplify the prophylactic and therapeutic treatment of COVID-19 in mice strongly suggests that enhancing the human IgM response or administering engineered IgM could significantly prevent SARSCoV-2 infection and improve outcome (241). New research studies regarding IgM function raise the likelihood that vaccine strategies aimed at preventing virus acquisition could include this ancient weapon (220). A summary of the pattern recognition 
proteins proinflammatory, anti-inflammatory and antiviral effects is shown in Table $\mathbf{1}$.

\section{PATTERN RECOGNITION PROTEINS AND THE BRIDGES WITH OTHER INNATE IMMUNE COMPONENTS AND ADAPTIVE IMMUNITY}

The SARS-CoV-2 pandemic is teaching us on the vital need to reestablish immune regulation to beat the virus (242). The systemic inflammation caused by massive cytokine release triggered during the viral infection involves elevated circulating cytokine levels and hyper-activation of immune system responses. This influenza-like syndrome triggers alveolar-, atherosclerotic plaque- and other organ-associated macrophages to produce an enormous amount of cytokines causing the cytokine storm and complications such as pneumonia and vascular thrombosis. As we described above, modifications of the host immune response to restore immune equilibrium is a fundamental approach to minimize disease severity and avoid death.

The immune response during a viral infection like COVID-19 involves more than the innate immunity with the participation of pattern recognition proteins. The SARS-CoV-2-associated tissue damage may be due to cytokines, acute phase physiological changes or immune-cell-mediated responses and result in severe pneumonia, intravascular coagulation and death. Marked elevations of interferon- $\gamma$, interleukin-6, interleukin-10 and interleukin- 2 receptor $\alpha$, a marker of T-cell activation, among others, point out the roles of inflammation and different immune response participants during COVID-19 infection (242). Although the paramount cytokine involved in the pathogenesis of COVID-19 has not been identified yet, interleukin-6 seems to be crucial (243). Inflammation limits invasive pathogens and resolves injuries by activating innate and adaptive immune responses.

The cells of the innate immune system are the first line of defense against microorganisms. Neutrophils, monocytes, and macrophages recognize microorganisms like SARS-CoV-2, produce cytokines, and phagocytize microorganisms and apoptotic/infected cells. Other innate

TABLE 1 | Summary of pattern recognition proteins (PRPs) proinflammatory, anti-inflammatory and antiviral effects.

\begin{tabular}{|c|c|c|c|}
\hline $\begin{array}{l}\text { Pattern recogni- } \\
\text { tion proteins } \\
\text { (PRPs) }\end{array}$ & Proinflammatory effects & Anti-inflammatory effects & Effects on RNA viruses \\
\hline $\begin{array}{l}\text { Surfactant } \\
\text { protein D (SP-D) }\end{array}$ & $\begin{array}{l}\text { Trimer, monomer- CD91-CRT/OSCAR; enhance } \\
\text { TNF- } \alpha \text { and atherogenesis; overwhelmed } \\
\text { inflammation }\end{array}$ & $\begin{array}{l}\text { Dodecamer, fuzzy form-apoptotic cells/ } \\
\text { CD91-CRT; enhance phagocytosis; SP- } \\
\text { D-SIRP } \alpha \text { : anti-inflammatory }\end{array}$ & $\begin{array}{l}\text { Anti-influenza through carbohydrate recognition } \\
\text { domain-binding; virus aggregation/neutralization; } \\
\text { hemagglutinin/neuraminidase activity (influenza) } \\
\text { inhibition }\end{array}$ \\
\hline $\begin{array}{l}\text { Surfactant } \\
\text { protein A (SP-A) }\end{array}$ & $\begin{array}{l}\text { Abnormal clearance of apoptotic cells; } \\
\text { Overwhelmed inflammation }\end{array}$ & $\begin{array}{l}\text { SP-A-apoptotic cells/CRT-CD91; } \\
\text { enhances phagocytosis and } \\
\text { macrophage TGF- } \beta\end{array}$ & $\begin{array}{l}\text { RNA virus (Influenza) agglutination and macrophage } \\
\text { uptake; hemagglutinin inhibition }\end{array}$ \\
\hline $\begin{array}{l}\text { Mannose- } \\
\text { binding lectin } \\
\text { (MBL) }\end{array}$ & $\begin{array}{l}\text { Overwhelmed inflammation; Abnormal } \\
\text { macrophage uptake of apoptotic cells }\end{array}$ & $\begin{array}{l}\text { MBL-apoptotic cells/CRT-CD91; } \\
\text { enhance phagocytosis }\end{array}$ & RNA virus/apoptotic cell macrophage uptake \\
\hline $\begin{array}{l}\text { Complement } \\
\text { component 1q } \\
\text { (C1q) }\end{array}$ & $\begin{array}{l}\text { Overwhelmed inflammation; Abnormal } \\
\text { macrophage uptake of apoptotic cells }\end{array}$ & $\begin{array}{l}\text { C1q-apoptotic cells/CRT-CD91; } \\
\text { enhance phagocytosis }\end{array}$ & RNA virus/apoptotic cell macrophage uptake \\
\hline $\begin{array}{l}\text { Native C- } \\
\text { reactive protein } \\
\text { (nCRP) }\end{array}$ & $\begin{array}{l}\text { Pentameric nCRP-FcyRl/FcyRlla: increases } \\
\text { inflammatory cytokine release; nCRP- Fc } \gamma R \text { Rllb } \\
\text { maintains a predominant anti-inflammatory effect }\end{array}$ & $\begin{array}{l}\text { Pentameric nCRP bound to } \\
\text { phosphorylcholine (PC) or lysoPC- } \\
\text { apoptotic cells, C1q and factor } \mathrm{H} \text { : } \\
\text { enhance phagocytosis; nCRP-FcyRs: } \\
\text { M2 response }\end{array}$ & $\begin{array}{l}\text { Pentameric nCRP facilitates antimicrobial activity in } \\
\text { pneumonia complicating COVID-19 infection }\end{array}$ \\
\hline $\begin{array}{l}\text { Non-native CRP } \\
\text { (nnCRP) }\end{array}$ & $\begin{array}{l}\text { Enhances inflammation and complement } \\
\text { activation; induces atherogenesis; mostly } \\
\text { proinflammatory }\end{array}$ & $\begin{array}{l}\text { It binds atherogenic LDL, reduces foam } \\
\text { cell formation and could also be } \\
\text { atheroprotective }\end{array}$ & $\begin{array}{l}\text { Very high CRP levels in COVID-19-associated } \\
\text { hyperinflammation could promote nnCRP generation } \\
\text { and inflammation }\end{array}$ \\
\hline $\begin{array}{l}\text { Monomeric CRP } \\
\text { (mCRP) }\end{array}$ & $\begin{array}{l}\text { Promotes chemotaxis; increases IL-8, MCP-1 and } \\
\text { nitric oxide; induces ROS; mCRP-FcyRIII induce } \\
\text { inflammation; promotes adhesion molecule } \\
\text { expression, thrombosis and atherogenesis }\end{array}$ & $\begin{array}{l}\text { Monomeric mCRP is mainly } \\
\text { proinflammatory and not anti- } \\
\text { inflammatory }\end{array}$ & $\begin{array}{l}\text { Very high CRP levels in COVID-19-associated } \\
\text { hyperinflammation could promote mCRP generation, } \\
\text { inflammation, thrombosis and atherogenesis and } \\
\text { plaque instability mediated by MMP1, } 2 \text { and } 9\end{array}$ \\
\hline $\begin{array}{l}\text { Natural (innate) } \\
\text { Immunoglobulin } \\
\text { M (IgM) }\end{array}$ & $\begin{array}{l}\text { Lack of innate lgM response allows cell necrosis } \\
\text { and inflammation. Lung inflammation promotes } \\
\text { apoptotic cell clearance }\end{array}$ & $\begin{array}{l}\text { Non-inflammatory clearance of } \\
\text { apoptotic cells; enhances virus and } \\
\text { bacteria phagocytosis }\end{array}$ & $\begin{array}{l}\text { Ancient antiviral weapon. IgM-enriched intravenous } \\
\text { immunoglobulins (pentaglobin) will enhance antiviral } \\
\text { protection against COVID-19 and apoptotic cell } \\
\text { removal }\end{array}$ \\
\hline $\begin{array}{l}\text { Immune } \\
\text { (adaptive) IgM }\end{array}$ & $\begin{array}{l}\text { Lack of innate lgM response allows cell necrosis } \\
\text { and inflammation }\end{array}$ & $\begin{array}{l}\text { Non-inflammatory clearance of } \\
\text { apoptotic cells; enhances virus and } \\
\text { bacteria phagocytosis }\end{array}$ & $\begin{array}{l}\text { Ancient antiviral weapon. IgM-enriched intravenous } \\
\text { immunoglobulins (pentaglobin) will enhance antiviral } \\
\text { protection against COVID-19 and apoptotic cell } \\
\text { removal }\end{array}$ \\
\hline
\end{tabular}

RNA, ribonucleic acid; CRT, calreticulin; OSCAR, osteoclast-associated receptor; SIRP $\alpha$, signal inhibitory regulatory protein $\alpha$; TGF- $\beta$, transforming growth factor- $\beta$; FC $\}$, FC $\gamma$ receptor; IL, interleukin; MCP-1, monocyte chemoattractant protein-1; ROS, reactive oxygen species. 
immune cells, such as dendritic cells, gamma-delta T cells, and natural killer (NK) cells participate in defense mechanisms (Figure 11). Innate immune cells use pattern recognition receptors, which are not specific for any particular antigen, to recognize and respond to a wide variety of microbial invaders by producing cytokines that activate cells of the adaptive immune system. Macrophages normally promote phagocytosis, tissue repair, immunoregulation, antigen presentation, and cytokine production (244) (Figure 11). Excessive cytokine production during cytokine storm in SARS-CoV-2 infection causes severe tissue damage and organ failure $(245,246)$. Neutrophils produce a network of fibers containing webs of chromatin, microbicidal proteins, and oxidant enzymes called neutrophil extracellular traps (NETs) that contain infections, but when not properly regulated, NETs can propagate inflammation and vascular thrombosis (247-263). Extracellular traps are not limited to neutrophils but include eosinophils, basophils and mast cells (264) (Figure 11). Severe COVID-19 results in early interleukin (IL)-6, IL-10 and IL-1 $\beta$ enhanced hyperinflammation (243).
This inflammatory environment is led by an abnormal function of innate immune cells that include monocytes, macrophages and natural killer cells that distribute viral pathogen-associated molecular patterns and damage-associated molecular patterns into tissues. Monocyte-derived tissue macrophages normally involved in phagocytosis, clearance of apoptotic cells, tissue repair, immunoregulation and antigen presentation, release excessive amounts of cytokines during COVID-19 infections that lead to tissue damage and organ failure $(232,233)$. Macrophages normally produce inflammatory molecules that eliminate microorganisms, and pattern recognition proteins like CRP, innate IgM and complement facilitate phagocytosis of infected apoptotic cells promoting tissue repair. Hyperinflammation in severe COVID19 infection, however, causes a dysregulated macrophage response, excessive cytokine production and tissue damage $(245,246)$. Dendritic cells are involved in linking innate and adaptative immunity against viral infections. Dendritic cells

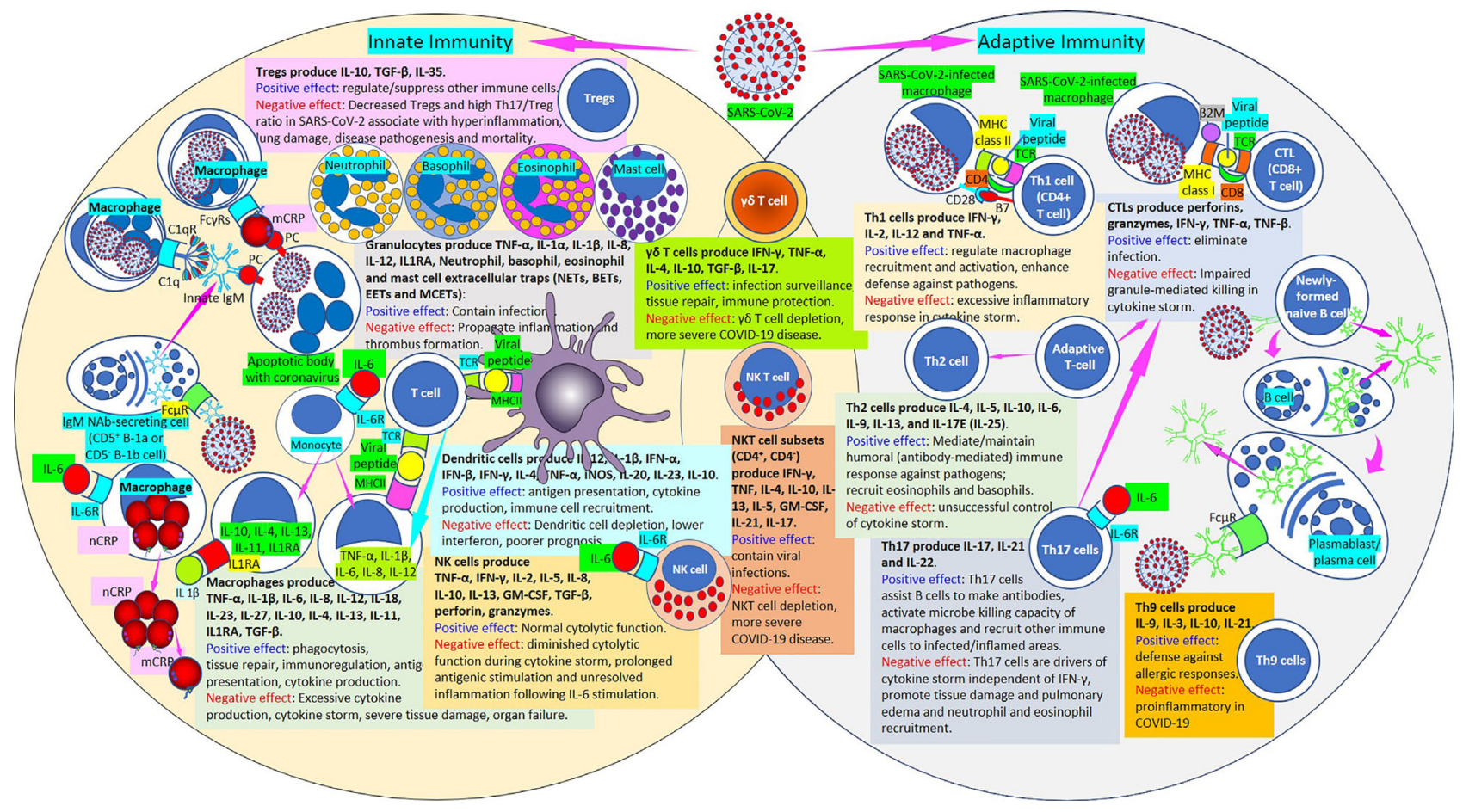

FIGURE 11 | Innate and adaptive immunity in SARS-CoV-2. [Left circle] The innate immune response functions as the first line of defense against infection. It consists of soluble factors, such as native (n) and monomeric (m) C-reactive protein (CRP) produced by liver and macrophages locally; innate lgM produced by B cells; complement proteins $(\mathrm{C} 1 \mathrm{q})$, and diverse cellular components including granulocytes (basophils, eosinophils and neutrophils), mast cells, monocytes, macrophages, dendritic cells, regulatory T cells (Tregs) and natural killer cells. [Middle intersection] Natural killer T cells and $\gamma \delta \mathrm{T}$ cells are cytotoxic lymphocytes that straddle the interface of innate and adaptive immunity. [Right circle] The adaptive immune response is slower to develop, but manifests as increased antigenic specificity and memory. It consists of antibodies, B cells that produce adaptive IgM and other antibodies, Th1 CD4 ${ }^{+}, \mathrm{CTL}$ CD8+ T lymphocytes, Th2 cells, Th17 cells, Th9 cells, among others. SARS-CoV-2, severe acute respiratory syndrome coronavirus; Tregs, regulatory T cells; IL, interleukin; Th, T helper; TNF, tumor necrosis factor; IL1RA, IL-1 receptor antagonist; NETs, neutrophil extracellular traps; BETs, basophil extracellular traps; EETs, eosinophil extracellular traps; MCETs,

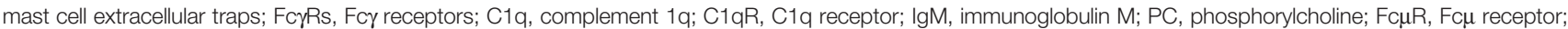
IL-6R, IL-6 receptor; CRP, C-reactive protein; nCRP, native CRP; mCRP monomeric CRP; TGF- $\beta$, transforming growth factor- $\beta$; TCR, T cell receptor; MHCII, major histocompatibility antigen class II; IFN, interferon; NK cell, natural killer cell; NKT cell, natural killer T cell; GM-CSF, granulocyte-macrophage colony-stimulating factor; iNOS, inducible nitric oxide synthase; COVID-19, coronavirus disease-2019; $\beta 2 \mathrm{M}, \beta 2$ microglobulin; MHC class I, major histocompatibility antigen class I; CTL, cytotoxic lymphocyte. 
normally participate in antigen presentation, cytokine production and immune cell recruitment; and dendritic cell dysfunction and dendritic cell depletion occur during SARSCoV-2 infection, which are associated with lower Interferon I response and poorer prognosis. Dendritic cell changes contribute to COVID-19 pathogenesis and increased susceptibility to worst outcomes especially in the elderly (265).

Natural killer cells normally induce cytotoxicity $(266,267)$ and diminished cytolytic function during cytokine storm in COVID-19 disease prolong antigenic stimulation and unresolved inflammation following IL-6 stimulation (268-272). Regulatory T cells (Tregs) suppress activation, proliferation and cytokine production of $\mathrm{CD} 4^{+} \mathrm{T}$ cells and $\mathrm{CD} 8^{+} \mathrm{T}$ cells and are thought to suppress B cells and dendritic cells, being involved in immune tolerance. Tregs can produce soluble messengers which have a suppressive function, including transforming growth factor-beta and IL-10 $(273,274)$. The level of Tregs in severe COVID-19 disease is extremely reduced and increasing and restoring Tregs needs to be considered in order to reduce severity and perhaps improve outcomes (275-277). Gammadelta $(\gamma \delta)$ T cells have unique antigen recognition capacity, tissue tropism, and cytotoxic abilities that allow them to participate in infection surveillance, tissue repair and durable immune protection (278-280). Natural killer T (NKT) cells show remarkable heterogeneity among NKT cell subsets and have potent immunoregulatory functions in infectious diseases such as COVID-19 (281) since NKT cell depletion and a diminished cytotoxic potential is associated with more severe COVID-19 disease (282-284).

Normally T helper type 1 cells (Th1 cells; $\mathrm{CD} 4^{+} \mathrm{T}$ cells) regulate macrophage recruitment and activation enhancing defense against pathogens; Th2 cells mediate and maintain humoral (antibodymediated) immune response against pathogens and recruit eosinophils and basophils; cytotoxic $\mathrm{CD}^{+} \mathrm{T}$ cells eliminate infection (285); Th9 cells intervene in defense against allergic responses; and Th17 cells assist B cells to make antibodies, activate the microbe killing capacity of macrophages and recruit other immune cells to infected and inflamed areas. SARS-CoV-2 infection is characterized by an excessive inflammatory response associated with a cytokine storm and a prominent lymphopenia affecting $\mathrm{CD}^{+}{ }^{+} \mathrm{T}$ cells, $\mathrm{CD} 8^{+} \mathrm{T}$ cells, B cells and natural killer cells (286). Both Lymphopenia and the cytokine storm determine increased COVID-19 disease severity and enhanced mortality (286-289). Lymphopenia has been associated with high levels of IL-6, IL-10 or tumor necrosis factor (286); IL-6 seeming to play a paramount role $(287,288,290)$. The severity of COVID-19 disease seems to relate to significant reduction of Th1 cells (291) and activation of Th9 cells (243) and unsuccessful control of the cytokine storm by Th2 cells. Individuals who die are more likely to have not mounted a $\mathrm{CD}^{+}$Th1 cellular response to the membrane, nucleocapsid, and spike proteins of the virus (292). Enhanced responses of Th17 cells (IL-17, IL-23) and decreased responses of Treg cells (TGF- $\beta$, IL-10) and high ratios of Th17/Treg cells in SARS-CoV-2-infected patients has a strong relationship with hyperinflammation, eosinophilic responses, allergic disorders, lung damage, and COVID-19 disease pathogenesis (293).

\section{SUMMARY, CONCLUSIONS AND NEW TREATMENT HORIZONS FOR CORONAVIRUS AND OTHER RNA VIRUSES}

A multiweapon approach against SARS-CoV-2 infection is the best arsenal available to date to avoid development of severe COVID-19 disease and reduce mortality. The availability of vaccines that prevent severe disease, intensive care admission and death are paramount in order to reduce and prevent transmission (294). COVID-19 vaccine candidates can be grouped into three broad categories: (a) protein- based vaccines (inactivated virus vaccines, virus- like particles and protein subunit vaccines); (b) gene- based vaccines (virusvectored vaccines, DNA vaccines and mRNA vaccines); and, (c) a combination of both protein- based and gene- based approaches (live- attenuated virus vaccines) (295). Vaccineinduced neutralizing antibodies (nAbs) are mainly produced against (1) whole virus [Inactivated virus, PiCoVacc, Sinovac, China: nAbs (296, 297); Inactivated virus, BBIBP-CorV, Sinopharm, China: nAbs (298-300)]; (2) S1-protein receptor binding domain [Virus vector Ad5, CanSino Biological: nAbs and $T_{H} 1$ responses $(301,302)$; Virus vector ChAdOx1, AstraZeneca: nAbs (303, 304); Virus vector Ad26 and Ad5, Gamaleya Research, Russia: nAbs and T-cell responses (305)] and (3) S1-protein with two proline substitutions at residues K986 and V987 [LNP-mRNA, Moderna $(306,307)$ and BioNTech with Fosun Pharma and Pfizer: nAbs and high TH1 with low TH2 responses (308, 309); Protein subunit CHO, Novavax (310); Virus-vectored Ad26, Janssen Pharmaceuticals (311)]. Vaccines induce neutralizing antibody and $\mathrm{CD}^{+}$and $\mathrm{CD}^{+} \mathrm{T}$-cell responses to the viral S protein (295).

The enhancement of components of innate human immunity needs to be seriously considered as part of the immediate armamentarium to prevent the development and progression of a serious viral infection and avoid severe inflammation of the lungs and other organs and cytokine storm that lead to higher morbidity and mortality. This is particularly important and relevant given the COVID-19 pandemic. Prior research suggests that the effective removal of apoptotic cells is fundamental for the resolution of acute injury and stimulation of tissue repair in the lung and other organs (56). Conversely, impaired clearance of apoptotic cells renders the tissues susceptible to chronic inflammation and contributes to the pathogenesis of pulmonary and other organ diseases. Under normal circumstances, alveolar macrophages, the principal macrophage cell in the lung, has a poor capacity to clear apoptotic cells, but in an inflammatory environment, alveolar macrophages develop a phagocytic capacity similar to that of other macrophages (56). These findings therefore lead to the intriguing hypothesis that the normal lung environment suppresses phagocytosis, whereas the environment present within an inflamed lung promotes apoptotic cell clearance.

Pattern recognition proteins (PRPs) like surfactant proteins A and $\mathrm{D}$, mannose binding lectin, $\mathrm{Clq}, \mathrm{C}$-reactive protein, and IgM 
natural antibodies function as components of the innate immune system through the recognition of pathogen-associated molecular patterns (PAMPs) (e.g., RNA viruses) and damageassociated molecular patterns (DAMPs) (e.g., apoptotic cells) and subsequent facilitation of foreign particle clearance by alveolar macrophages and other macrophages in different tissues. Interestingly, PRPs perform two different roles, either pro-inflammatory or anti-inflammatory. For example, SP-A and SP-D contribute to the innate immune response by facilitating pathogen and apoptotic cell removal enhancing the proinflammatory response to viral and other infections (56). Conversely, SP-A and SP-D inhibit macrophage proinflammatory mediators. The reason for the paradox showing opposite effects of the same molecules is associated with the orientation by which the molecules bind to their respective receptors, and the type of receptor to which they are binding. For example, N-terminal collagen domain ligation with the calreticulin/CD91 receptor complex is proinflammatory, while binding of the $\mathrm{C}$ terminal heads to SIRP $\alpha$ prevents inflammation. Thus, in the naive lung, binding of SP-A and SP-D to SIRP $\alpha$ on the alveolar macrophages may inhibit uptake of apoptotic cells, resulting in the inefficient digestion observed for these cells. During inflammation, this inhibitory effect is replaced by a proinflammatory effect to facilitate apoptotic cell removal (56). In the resting, noninflamed lung, the lung collectins SP-A and SP-D have dual effects. On one hand, they suppress alveolar macrophage phagocytic function through their interaction with SIRP $\alpha$. On the other hand, SP-A and SP-D enhance apoptotic cell removal by opsonization of apoptotic cells and facilitation of their removal through calreticulin/CD91. The net effect allows low-level phagocytosis of apoptotic cells by resting alveolar macrophages during times of health yet maintains their resting phenotype (56).

The introduction of recombinant human SP-A and SP-D suggest that pattern recognition proteins may be used as antiinfective/anti-inflammatory therapies $(66,69,312,313)$ (Figure 12). SP-A and SP-D $(70,71)$ are structurally like the viral fusion proteins they specifically bind and could be used to develop new anti-infective, and immune-modulatory therapies $(70,71)$. Recombinant forms of SP-D recently developed could be used therapeutically $(60,66,67,69,312-314)$ to reduce inflammatory processes in pulmonary diseases associated with viral infections like COVID-19. Treatment with recombinant human SP-D-containing surfactant inhibits lung inflammation and enhances the resistance of surfactant to inhibition, reinforcing its potential usefulness for the prevention of lung injury in preterm newborns (314). Administration of a truncated $60-\mathrm{kDa}$ fragment of human recombinant SP-D within the lung reduces the number of apoptotic and necrotic alveolar macrophages and partially corrects the lipid accumulation in SP-D-deficient mice. The same SP-D fragment binds specially to apoptotic and necrotic alveolar macrophages in vitro, what suggests that SP-D contributes to lung immune homeostasis by recognizing and promoting removal of necrotic and apoptotic cells (315). Therefore, SP-D administration could be another useful way to diminish apoptosis and inflammation in coronavirus-associated pulmonary disease. The observation that vascular SP-D expression may be harmful in atherogenesis implies that therapies directed to specifically inhibit low molecular weight SP-D signaling may ameliorate development of atherosclerosis, since, whereas SP-D predominantly serves as an overall host friendly innate immune molecule in both pulmonary and cardiovascular systems, low molecular weight SP-D, not multimeric SP-D appears to change into foe during development of cardiovascular disease $(100,101)$. Although no clinical trials treating patients with full-length recombinant SP-D have yet been performed, the body of preclinical data supports significant treatment effect (100).

The potential use of pulmonary surfactant to deliver fulllength recombinant human surfactant protein SP-D (rhSP-D) using the respiratory air-liquid interface as a vehicle (316) is a promising approach to add to the arsenal against SARS-CoV-2 infection. The interaction of SP-D with surfactant constituents, the potential use of phosphatidylserine as a respiratory drug delivery system and the likelihood to produce recombinant human SP-D, brings the chance of delivering clinical SP-Dsupplemented surfactants (316). Recent data highlight the therapeutic potential of a recombinant fragment of human SPD (rfhSP-D) composed of 8 Gly-X-Y repeats, neck and CRD region against influenza and other viruses (71). This molecule binds the S1 spike protein of SARS-CoV-2 and its receptor binding domain inhibiting its interaction with the human ACE2 receptor $(66,69,71)$, impeding viral entry to the host cells mediated by the ACE2 receptor following $S$ protein cleavage by transmembrane protease serine 2 (TMPRSS2) into S1 and S2 portions (71). These data show the therapeutic potential of fulllength SP-D and its fragments in SARS-CoV-2 infection $(66,69-$ 71). As recently suggested, both recombinant SP-A and SP-D could be therapeutically relevant by blocking SARS-CoV-2 viral infection and concomitantly modulating the immune system preventing excessive inflammatory responses associated with the cytokine storm seen during COVID-19 disease (70). Interestingly, recombinant SP-A and SP-D could be therapeutically useful with current and future SARS-CoV-2 strains and the therapeutic modulation of the immunopathology caused by the COVID-19 disease (70). Previous studies showed that porcine SP-D (pSP-D) has particular influenza A antiviral activity as compared to human SP-D (hSP-D), as a result of key residues in the lectin domain of pSP-D that contribute to its profound neutralizing activity. These observations provided the basis for the design of a full-length recombinant mutant form of hSP-D, designated as "improved SP-D" (iSP-D) (66). Proteins like iSP-D could serve as novel human-based antiviral inhalation drugs against respiratory (pandemic) influenza $A$ and SARS-CoV-2 infections in humans. Recent studies have shown that targeting the SP-A and SP-D inhibitory receptor SIRP $\alpha$ could be a novel approach to reduce pneumonia, a life-threatening complication in COVID-19 infection (317). Antibody blockade of SIRP $\alpha$ restored phagocytosis in monocytes of critically ill patients suggesting a potential strategy to prevent hospital-acquired pneumonia as a result of the SARS-CoV-2 pandemic (317, 


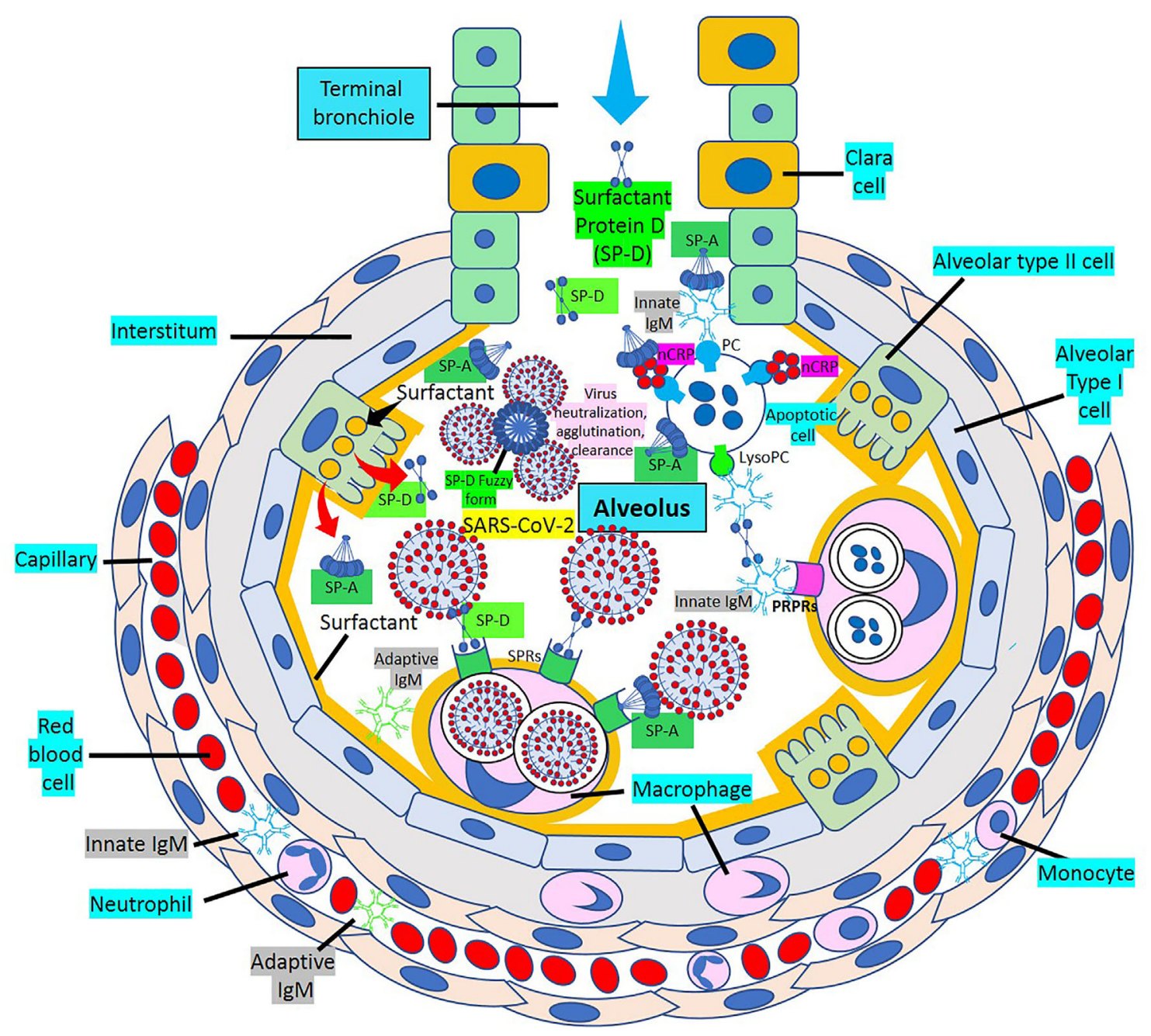

FIGURE 12 | Pattern recognition protein treatment of SARS-Cov-2-related disease. Inhaled surfactant protein D (SP-D) treatment in association with endogenous SP-D and SP-A facilitates neutralization of SARS-CoV-2 particles that can be phagocytosed by alveolar macrophages via surfactant protein receptors (SPRs). Other pattern recognition proteins (PRPs) participate in the removal of apoptotic cells like native pentameric C-reactive protein (nCRP) bound to phosphorylcholine (PC), innate IgM/SP-A, CRP/SP-A and SP-A in apoptotic cells, in association with SP-D and innate/adaptive lgM molecules via pattern recognition protein receptors (PRPRs). lysoPC, lysophosphatidylcholine.

318). The use of SIRP $\alpha$ antibodies have been proven effective in reducing the CD47/SIRP $\alpha$ inhibitory "do-not-eat-me" signal to macrophages, allowing enhanced phagocytosis of tumor cells (81). These data suggest that disrupting SIRP/CD47 macrophage signaling, either by internalization or disruption of the SIRP $\alpha$ structure associated with Fc $\gamma \mathrm{R}$ engagement, could allow macrophages to maximize their phagocytic potential against SARS-CoV-2-infected cells.

The mechanism of action most extensively reported for the antiviral effects of pattern recognition proteins relates to their ability to attach to virus particles and subsequently block viruscell interaction. Binding of CRP to the virus and/or the cell membrane can impair subsequent virus attachment and entry into the cell (201). Besides the possible therapeutic benefits of pattern recognition proteins like CRP, changes in pattern recognition protein expression following administration of antiviral drugs and vaccines suggest the possible use of these proteins as markers of disease progression and efficacy of antiviral treatments; and CRP may be a target for the management of severe influenza diseases (201). We described above that the pentameric form of CRP, nCRP has mostly antiinflammatory properties whereas mCRP has mostly proinflammatory effects (319). Interestingly, the compound 1,6-bis (phosphocholine)-hexane, a derivative of CRP-ligand phosphocholine, can prevent dissociation of nCRP, and subsequently inhibit the generation and pro-inflammatory activity of mCRP $(123,150)$, and can inhibit mCRP deposition and inflammation in myocardial infarction (150, 320, 321). Treatment with 1,6-bis phosphocholine-hexane reduces the inflammatory lesions in lung tissues infected with lethal 
influenza virus while reducing the production of CRP and reducing mortality after influenza infection (197). When we consider the properties of all CRP isoforms, it can be sustained that CRP possesses the functionality of a host defense molecule against not only atherosclerosis but against all diseases caused by proteins that behave like pathogens or toxic molecules, in a life cycle beginning as free circulatory CRP and ending in ligandbound MCRP at sites of inflammation via an intermediate stage of non-native pentamers $(181,188)$. Although CRP inhibitor drugs are being studied for future treatment, perhaps developing better compounds that avoid the monomerization of CRP could be a more effective way to diminish tissue mCRP and inflammation $(320,321)$. An extracorporeal device to deplete CRP from human plasma by adsorption to beads functionalized with phosphocholine (PentraSorb CRP) has been introduced (322). It is intended for application in patients suffering from acute myocardial infarction or from other acute inflammatory disorders with elevated CRP plasma levels (322). Selective serum CRP immuno-adsorption has been shown to efficiently reduce CRP concentrations by $60 \%$ within hours (323). This approach opens a new door for possible treatment of patients with SARS$\mathrm{CoV}-2$ infection and severe disease showing very high levels of CRP.

Several strategies designed to enhance natural IgM levels have been described in recent investigations. Patients frequently develop a selective loss of circulating IgM displaying a concomitant augmented susceptibility to certain types of infections, following splenectomy or thermal injury (324). The use of Pneumococcal vaccination and i.v. administration of IgM natural antibodies (IgM NAbs) could be an alternative to neutralize viral and bacterial infections that severily increase morbidity and mortality during SARS-CoV-2 infections. Pneumococcal vaccination employs and takes advantage of the molecular mimicry that exists among the PC moieties of microbial cell-wall polysaccharide, unfractionated OxLDL, and apoptotic cells (324). Since normal human plasma contains a great amount of IgM NAbs, it may be practical and economically feasible to exploit the therapeutic potential of these IgM through production of therapeutic preparations in a way analogous to intravenous immunoglobulins that is now extensively used for the treatment of a wide range of pathological conditions. Intravenous immunoglobulins deliver effective antimicrobial activity irrespective of pathogen resistance and represent a promising alternative strategy for the treatment of diseases for which a specific therapy is not yet available. This is based on the diverse repertoire of immunoglobulins having a wide spectrum of antibacterial and antiviral specificities that are present in intravenous immunoglobulin preparations. Controlled trials, particularly with viral diseases and certain defined septic subgroups where intravenous immunoglobulins represent a promising but unproven treatment, are imperative (325). IgMenriched Ig preparations, pentaglobin, contain $12 \% \operatorname{IgM}$, and were successfully used for the treatment of patients with infections associated with sepsis, as well as for transplant rejection, and for certain inflammatory experimental conditions (324).
Surfactant, a complex mixture of phospholipids and proteins that reduces surface tension at the alveolar air-liquid interface, is made up of $70-80 \%$ phospholipids, $10 \%$ surfactant proteins (SP)A, B, C and D, and $10 \%$ neutral lipids $(326,327)$. It has been demonstrated that SP-D and SP-A, two pattern recognition proteins of the innate immune system (328) bind influenza A RNA viruses, inhibiting attachment and entry of the virus and also contribute to enhanced clearance of SP-opsonized virus via interactions with phagocytic cells $(15,329)$. Other pattern recognition proteins, IgM NAbs, enhance late apoptotic cell clearance in the lungs by alveolar macrophages (330). In addition, SP-D modulates the inflammatory response and helps sustain an equilibrium between effective neutralization/ killing of influenza A viruses, and protection against alveolar damage resulting from influenza $A$ virus-induced excessive inflammatory responses. Pig SP-D exhibits distinct antiinfluenza A virus properties neutralizing a broad range of influenza A viruses and wild-type porcine SP-D exhibits strong antiviral properties against a much broader range of influenza $\mathrm{A}$ viral strains/subtypes compared to human SP-D as it is naturally expressed in the airways (15). It has been demonstrated that primary human alveolar type II cells infected with SARS-CoV, maintained under air-liquid conditions, can generate a vigorous innate immune response (331), and different cell culture systems mirroring the human airways are available, like the air-liquid interface human airway epithelium model that can be used to identify antivirals, evaluate compound toxicity and viral inhibition (332). Since IgM NAbs enhance pulmonary alveolar late apoptotic cell clearance (330), intravenous administration of IgM NAbs will intensify antiviral protection and late apoptotic cell removal in the lungs by alveolar macrophages.

The use of surfactant and SP-D as antiviral agents administered by inhalation and/or after tracheal intubation in patients requiring ventilators may offer several advantages. SP-D neutralizes a broad range of influenza $\mathrm{A}$ viruses and it is unlikely that a single genomic influenza A viral mutation would induce resistance against SP-D antiviral activity. Inhaled/intratracheal SP-D can provide acute protection against invading influenza A viral particles. Since SP-D is in surfactant, little toxicity and a relatively high immunogenic SP-D tolerance are anticipated in humans. Intravenous administration of IgM NAbs will enhance antiviral protection and late apoptotic cell clearance in the lungs by alveolar macrophages.

The induction of protective, long-term IgM responses may be achieved through active immunization. Vaccines involving longterm antiviral IgM responses may have advantages over conventional IgG responses against viruses that rapidly mutate, like human immunodeficiency virus and other RNA viruses that replicate by-way-of error-prone viral RNA dependent polymerases or often recombine with different viral strains (220). Considering that multimeric IgM can efficiently bind viral antigens with repeated epitopes resulting in viral agglutination, stimulating the production of these IgM antibodies could be another weapon destined to combat lethal RNA viruses like SARS-CoV-2. IgM responses have often been underestimated and assumed to be part of a transient immunity 
preceding the development of high-affinity IgG. IgM plays a more important role in microbial infections than has been generally appreciated, however, since IgM is highly effective in the prevention and in the elimination of numerous microbial infections. The properties of IgM allow for its utilization for prevention and treatment of infections, via immunization and/or passive antibody administration. A lot has been learned about both natural and immune IgM regarding their production by subsets of B-1 cells, but much still needs to be learned regarding the origins, development, and maintenance of B-1 cell responses. The knowledge acquired from the study of those responses should help with development of vaccines designed to generate effective long-lived IgM immunity (220, 223).

Finally, the success combating SARS-CoV-2 infections and COVID-19 disease needs to consider all lines of defense of the immune system. Although we emphasized the role of soluble components of the first line of defense of innate immunity like pattern recognition proteins (surfactant proteins $\mathrm{A}$ and $\mathrm{D}$, mannose-binding lectin and complement component 1q, Creactive protein, innate IgM antibodies), we cannot ignore the

\section{REFERENCES}

1. Morens DM, Taubenberger JK, Fauci AS. Pandemic Influenza Viruses Hoping for the Road Not Taken. N Engl J Med (2013) 368:2345-8. doi: 10.1056/ NEJMp1307009

2. Morens DM, Taubenberger JK, Fauci AS. The Persistent Legacy of the 1918 Influenza Virus. New Engl J Med (2009) 361:225-9. doi: 10.1056/NEJMp0904819

3. Zimmer SM, Burke DS. Historical Perspective - Emergence of Influenza A (H1N1) Viruses. N Engl J Med (2009) 361:279-85. doi: 10.1056/ NEJMra0904322

4. Cascella M, Rajnik M, Cuomo A, Dulebohn SC, Di Napoli R. Features, Evaluation and Treatment Coronavirus (COVID-19). In: StatPearls. Treasure Island (FL: StatPearls Publishing (2020). 2020 May 18. Bookshelf ID: NBK554776 PMID: 32150360.

5. Mittal A, Manjunath K, Ranjan RK, Kaushik S, Kumar S, Verma V. COVID-19 Pandemic: Insights Into Structure, Function, and hACE2 Receptor Recognition by SARS-CoV-2. PloS Pathog (2020) 16:e1008762. doi: 10.1371/ journal.ppat.1008762

6. Wang M-Y, Zhao R, Gao L-J, Gao X-F, Wang D-P, Cao J-M. SARS-CoV-2: Structure, Biology, and Structure-Based Therapeutics Development. Front Cell Infect Microbiol (2020) 10:587269. doi: 10.3389/fcimb.2020.587269

7. Klein S, Cortese M, Winter SL, Wachsmuth-Melm M, Neufeldt CJ, Cerikan B, et al. SARS-CoV-2 Structure and Replication Characterized by in Situ CryoElectron Tomography. Nat Commun (2020) 11:5885. doi: 10.1038/s41467-02019619-7

8. Huang Y, Yang C, XU X-F, Xu W, Liu S-W. Structural and Functional Properties of SARS-CoV-2 Spike Protein: Potential Antivirus Drug Development for COVID-19. Acta Pharmacol Sin (2020) 41:1141-9. doi: 10.1038/s41401-020-0485-4

9. Astuti I, Ysrafil. Severe Acute Respiratory Syndrome Coronavirus 2 (SARSCoV-2): An Overview of Viral Structure and Host Response. Diabetes Metab Syndr (2020) 14:407-12. doi: 10.1016/j.dsx.2020.04.020

10. Walls AC, Park Y-J, Tortorici MA, Wall A, McGuire AT, Veesler D. Structure, Function, and Antigenicity of the SARS-CoV-2 Spike Glycoprotein. Cell (2020) 180:281-92. doi: 10.1016/j.cell.2020.02.058

11. Cui J, Li F, Shi ZL. Origin and Evolution of Pathogenic Coronaviruses. Nat Rev Microbiol (2019) 17:181-92. doi: 10.1038/s41579-018-0118-9

12. V'kovski P, Kratzel A, Steiner S, Stalder H, Thiel V. Coronavirus Biology and Replication: Implications for SARS- CoV-2. Nat Rev Microbiol (2021) 19:15570. doi: 10.1038/s41579-020-00468-6 role of cellular components of the innate immune system (neutrophils, basophils, eosinophils, mast cells, monocytes, macrophages, dendritic cells, regulatory $\mathrm{T}$ cells, natural killer cells), cellular components of both innate and adaptive immunity ( $\gamma \delta \mathrm{T}$ cells, natural killer $\mathrm{T}$ cells), soluble components of the adaptive immune system (polyreactive IgM antibodies generated in response to the viral disease, among others), and cellular components of the adaptive immune system ( $\mathrm{T}$ cell subsets like Th1 CD4+ T cells, cytotoxic CD8+ T cells, Th2 cells, Th17 cells, Th9 cells), as depicted in Figure 11. A combined therapeutic approach that takes into account all aspects of immunity against SARS-CoV-2 virus and COVID-19 disease will allow mankind to beat this pandemic killer.

\section{AUTHOR CONTRIBUTIONS}

All authors listed have made a substantial, direct, and intellectual contribution to the work, and approved it for publication.
13. Wang N, Shang J, Jiang S, Du L. Subunits Vaccines Against Emerging Pathogenic Human Coronaviruses. Front Microbiol (2020) 11:298. doi: $10.3389 /$ fmicb. 2020.00298

14. Fung TS, Liu DX. Human Coronavirus: Host-Pathogen Interaction. Annu Rev Microbiol (2019) 73:529-57. doi: 10.1146/annurev-micro-020518-115759

15. Hillaire MLB, Haagsman HP, Osterhaus ADME, Rimmelzwaan GF, van Eijk M. Pulmonary Surfactant Protein D in First-Line Innate Defence Against Influenza A Virus Infections. J Innate Immun (2013) 5:197-208. doi: 10.1159/ 000346374

16. Madjid M, Safavi-Naeini P, Solomon SD, Vardeny O. Potential Effects of Coronaviruses on the Cardiovascular System. A Review. JAMA Cardiol (2020) 5:831-40. doi: 10.1001/jamacardio.2020.1286

17. World Health Organization. WHO Coronavirus Disease (COVID-19) Dashboard. (2021).

18. Chung MK, Zidar DA, Bristow MR, Cameron SJ, Chan T, Harding CVIII, et al. COVID-19 and Cardiovascular Disease. From bench to bedside. Circ Res (2021) 128:1214-36. doi: 10.1161/CIRCRESAHA.121.317997

19. Bonow RO, Fonarow GC, O'Gara PT, Yancy CW. Association of Coronavirus Disease 2019 (COVID-19) With Myocardial Injury and Mortality. JAMA Cardiol (2020) 5:751-3. doi: 10.1001/jamacardio.2020.1105

20. Huang C, Wang Y, Li X, Ren L, Zhao J, Hu Y, et al. Clinical Features of Patients Infected With 2019 Novel Coronavirus in Wuhan, China. Lancet (2020) 395:497-506. doi: 10.1016/S0140-6736(20)30183-5

21. Chen N, Zhou M, Dong X, Qu J, Gong F, Han Y, et al. Epidemiological and Clinical Characteristics of 99 Cases of 2019 Novel Coronavirus Pneumonia in Wuhan, China: A Descriptive Study. Lancet (2020) 395:507-13. doi: 10.1016/ S0140-6736(20)30211-7

22. Wang D, Hu B, Hu C, Zhu F, Liu X, Zhang J, et al. Clinical Characteristics of 138 Hospitalized Patients With 2019 Novel Coronavirus-Infected Pneumonia in Wuhan, China. JAMA (2020) 323:1061-9. doi: 10.1001/jama.2020.1585

23. Wu Z, McGoogan JM. Characteristics of and Important Lessons From the Coronavirus Disease 2019 (COVID-19) Outbreak in China: Summary of a Report of 72314 Cases From the Chinese Center for Disease Control and Prevention. JAMA (2020). doi: 10.1001/jama.2020.2648

24. Guan W, Ni Z, Hu Y, Liang W, Ou C, He J, et al. China Medical Treatment Expert Group for Covid-19. Clinical Characteristics of Coronavirus Disease 2019 in China. N Engl J Med (2020) 382:1708-20. doi: 10.1056/NEJMoa2002032

25. Nishiga M, Wang DW, Han Y, Lewis DB, Wu JC. COVID-19 and Cardiovascular Disease: From Basic Mechanisms to Clinical Perspectives. Nat Rev Cardiol (2020) 17:543-58. doi: 10.1038/s41569-020-0413-9 
26. Madjid M, Miller CC, Zarubaev VV, Marinich IG, Kiselev OI, Lobzin YV, et al. Influenza Epidemics and Acute Respiratory Disease Activity are Associated With a Surge in Autopsy-Confirmed Coronary Heart Disease Death: Results From 8 Years of Autopsies in 34,892 Subjects. Eur Heart J (2007) 28(10):1205-10. doi: 10.1093/eurheartj/ehm035

27. Nguyen JL, Yang W, Ito K, Matte TD, Shaman J, Kinney PL. Seasonal Influenza Infections and Cardiovascular Disease Mortality. JAMA Cardiol (2016) 1:274-81. doi: 10.1001/jamacardio.2016.0433

28. Kwong JC, Schwartz KL, Campitelli MA, Chung H, Crowcroft NS, Karnauchow T, et al. Acute Myocardial Infarction After LaboratoryConfirmed Influenza Infection. N Engl J Med (2018) 378:345-53. doi: 10.1056/NEJMoa1702090

29. Smeeth L, Thomas SL, Hall AJ, Hubbard R, Farrington P, Vallance P. Risk of Myocardial Infarction and Stroke After Acute Infection or Vaccination. N Engl J Med (2004) 351:2611-8. doi: 10.1056/NEJMoa041747

30. Vinciguerra M, Romiti S, Fattouch K, De Bellis A, Greco E. Atherosclerosis as Pathogenetic Substrate for Sars-Cov2 Cytokine Storm. J Clin Med (2020) 9:2095. doi: 10.3390/jcm9072095

31. Xiong TY, Redwood S, Prendergast B, Chen M. Coronaviruses and the Cardiovascular System: Acute and Long-Term Implications. Eur Heart J (2020) 41:1798-800. doi: 10.1093/eurheartj/ehaa231

32. Song P, Li W, Xie J, Hou Y, You C. Cytokine Storm Induced by SARS-CoV-2. Clin Chim Acta (2020) 509:280-7. doi: 10.1016/j.cca.2020.06.017

33. Jafarzadeh A, Chauhan P, Saha B, Jafarzadeh S, Nemati M. Contribution of Monocytes and Macrophages to the Local Tissue Inflammation and Cytokine Storm in COVID-19: Lessons From SARS and MERS, and Potential Therapeutic Interventions. Life Sci (2020) 257:118102. doi: 10.1016/ j.lfs.2020.118102

34. Zhao M, Wang M, Zhang J, Ye J, Xu Y, Wang Z, et al. Advances in the Relationship Between Coronavirus Infection and Cardiovascular Diseases. BioMed Pharmacother (2020) 127:110230. doi: 10.1016/j.biopha.2020.110230

35. Clerkin KJ, Fried JA, Raikhelkar J, Sayer G, Griffin JM, Masoumi A, et al. COVID-19 and Cardiovascular Disease. Circulation (2020) 141:1648-55. doi: 10.1161/CIRCULATIONAHA.120.046941

36. Ali N. Elevated Level of C-Reactive Protein may be an Early Marker to Predict Risk for Severity of COVID-19. J Med Virol (2020) 92:2409-11. doi: 10.1002/ jmv.26097

37. Guo T, Fan Y, Chen M, Wu X, Zhang L, He T, et al. Cardiovascular Implications of Fatal Outcomes of Patients With Coronavirus Disease 2019 (COVID-19). JAMA Cardiol (2020) 5:811-8. doi: 10.1001/ jamacardio.2020.1017

38. Zhang H, Penninger JM, Li Y, Zhong N, Slutsky AS. Angiotensin-Converting Enzyme 2 (ACE2) as a SARS-CoV-2 Receptor: Molecular Mechanisms and Potential Therapeutic Target. Intensive Care Med (2020) 46:586-90. doi: 10.1007/s00134-020-05985-9

39. Gheblawi M, Wang K, Viveiros A, Nguyen Q, Zhong J-C, Turner AJ, et al. Angiotensin-Converting Enzyme 2: SARS-CoV-2 Receptor and Regulator of the Renin-Angiotensin System. Celebrating the 20th anniversary of the discovery of ACE2. Circ Res (2020) 126:1456-74. doi: 10.1161/ CIRCRESAHA.120.317015

40. Ni W, Yang X, Yang D, Bao J, Li R, Xiao Y, et al. Role of AngiotensinConverting Enzyme 2 (ACE2) in COVID-19. Crit Care (2020) 24:422. doi: 10.1186/s13054-020-03120-0

41. Bian J, Li Z. Angiotensin-Converting Enzyme 2 (ACE2): SARS-CoV-2 Receptor and RAS Modulator. Acta Pharm Sin B (2021) 11:1-12. doi: 10.1016/j.apsb.2020.10.006

42. Magro C, Mulvey JJ, Berlin D, Nuovo G, Salvatore S, Harp J, et al. Complement Associated Microvascular Injury and Thrombosis in the Pathogenesis of Severe COVID-19 Infection: A Report of Five Cases. Transl Res (2020) 220:1-13. doi: 10.1016/j.trsl.2020.04.007

43. Roulston A, Marcellus RC, Branton PE. Viruses and Apoptosis. Annu Rev Microbiol (1999) 53:577-628. doi: 10.1146/annurev.micro.53.1.577

44. Atkin-Smith GK, Duan M, Zanker DJ, Loh L, Nguyen THO, Koutsakos M, et al. Monocyte Apoptotic Bodies are Vehicles for Influenza A Virus Propagation. Commun Biol (2020) 3:223. doi: 10.1038/s42003-020-0955-8

45. Paolini A, Borella R, De Biasi S, Neroni A, Mattioli M, Lo Tartaro D, et al. Cell Death in Coronavirus Infections: Uncovering its Role During COVID-19. Cells (2021) 10:1585. doi: 10.3390/cells10071585
46. de Rivero Vaccari JC, Dietrich WD, Keane RW, de Rivero Vaccari JP. The Inflammasome in Times of COVID-19. Front Immunol (2020) 11:583373. doi: 10.3389/fimmu.2020.583373

47. Ferreira AC, Cardoso Soares V, de Azevedo-Quintanilha IG, da Silva Gomes Dias S, Fintelman-Rodrigues N, Sacramento CQ, et al. SARS-CoV-2 Engages Inflammasome and Pyroptosis in Human Primary Monocytes. Cell Death Discov (2021) 7:43. doi: 10.1038/s41420-021-00428-w

48. Zhang J, Wu H, Yao X, Zhang D, Zhou Y, Fu B, et al. Pyroptotic Macrophages Stimulate the SARS-CoV-2-Associated Cytokine Storm. Cell Mol Immunol (2021) 18:1305-7. doi: 10.1038/s41423-021-00665-0

49. Zheng M, Williams EP, Subbarao Malireddi RK, Karki R, Banoth B, Burton A, et al. Impaired NLRP3 Inflammasome Activation/Pyroptosis Leads to Robust Inflammatory Cell Death via Caspase-8/RIPK3 During Coronavirus Infection. J Biol Chem (2020) 295:14040-52. doi: 10.1074/jbc.RA120.015036

50. Yap JKY, Moriyama M, Iwasaki A. Inflammasomes and Pyroptosis as Therapeutic Targets for COVID-19. J Immunol (2020) 205:307-12. doi: 10.4049/jimmunol.2000513

51. Freeman TL, Swartz TH. Targeting the NLRP3 Inflammasome in Severe COVID-19. Front Immunol (2020) 11:1518. doi: 10.3389/fimmu.2020.01518

52. López-Reyes A, Martinez-Armenta C, Espinosa-Velázquez R, VázquezCárdenas P, Cruz-Ramos M, Palacios-Gonzalez B, et al. NLRP3 Inflammasome: The Stormy Link Between Obesity and COVID-19. Front Immunol (2020) 11:570251. doi: 10.3389/fimmu.2020.570251

53. Vora SM, Lieberman J, Wu H. Inflammasome Activation at the Crux of Severe COVID-19. Nat Rev Immunol (2021). doi: 10.1038/s41577-021-00588-x

54. Rodrigues TS, de Sá KSG, Ishimoto AY, Becerra A, Oliveira S, Almeida L, et al. Inflammasomes are Activated in Response to SARS-CoV-2 Infection and are Associated With COVID-19 Severity in Patients. J Exp Med (2020) 218: e20201707. doi: 10.1084/jem.20201707

55. Pastva AM, Wright JR, Williams KL. Immunomodulatory Roles of Surfactant Proteins A and D. Implications in Lung Disease. Proc Am Thorac Soc (2007) 4:252-7. doi: 10.1513/pats.200701-018AW

56. Wright JR. Immunoregulatory Functions of Surfactant Proteins. Nat Rev Immunol (2005) 5:58-68. doi: 10.1038/nri1528

57. Kishore U, Greenhough TJ, Waters P, Shrive AK, Ghai R, Kamran MF, et al. Surfactant Proteins SP-A and SP-D: Structure, Function and Receptors. Mol Immunol (2006) 43:1293-315. doi: 10.1016/j.molimm.2005.08.004

58. Nayak A, Dodagatta-Marri E, Tsolaki AG, Kishore U. An Insight Into the Diverse Roles of Surfactant Proteins, SP-A and SP-D in Innate and Adaptive Immunity. Front Immunol (2012) 3:131. doi: 10.3389/fimmu.2012.00131

59. Baker SA, Kwok S, Berry GJ, Montine TJ. Angiotensin-Converting Enzyme 2 (ACE2) Expression Increases With Age in Patients Requiring Mechanical Ventilation. PloS One (2021) 16:e0247060. doi: 10.1371/journal.pone.0247060

60. Wang S, Li Z, Wang X, Zhang S, Gao P, Shi Z. The Role of Pulmonary Surfactants in the Treatment of Acute Respiratory Distress Syndrome in COVID-19. Front Pharmacol (2021) 12:698905. doi: 10.3389/fphar.2021.698905

61. Zhao Y, Zhao Z, Wang Y, Zhou Y, Ma Y, Zuo W. Single-Cell RNA Expression Profiling of ACE2, the Receptor of SARS-CoV-2. Am J Respir Crit Care Med (2020) 202:756-9. doi: 10.1164/rccm.202001-0179LE

62. Groß S, Jahn C, Cushman S, Bär C, Thum T. SARS-CoV-2 Receptor ACE2Dependent Implications on the Cardiovascular System: From Basic Science to Clinical Implications. J Mol Cell Cardiol (2020) 144:47-53. doi: 10.1016/ j.yjmcc.2020.04.031

63. Sharma RK, Stevens BR, Obukhov AG, Grant MB, Oudit GY, Li Q, et al. ACE2 (Angiotensin Converting Enzyme 2) in Cardiopulmonary Diseases. Ramifications for the Control of SARS-CoV-2. Hypertension (2020) 76:65161. doi: 10.1161/HYPERTENSIONAHA.120.15595

64. Verdecchia P, Cavallini C, Spanevello A, Angeli F. The Pivotal Link Between ACE2 Deficiency and SARS-CoV-2 Infection. Eur J Intern Med (2020) 76:1420. doi: 10.1016/j.ejim.2020.04.037

65. Davidson AM, Wysocki J, Batlle D. Interaction of SARS-CoV-2 and Other Coronavirus With ACE (Angiotensin-Converting Enzyme)-2 as Their Main Receptor. Therapeutic Implications. Hypertension (2020) 76:1339-49. doi: 10.1161/HYPERTENSIONAHA.120.15256

66. Van Eijk M, Hillaire MLB, Rimmelzwaan GF, Rynkiewicz MJ, White MR Hartshorn KL, et al. Enhanced Antiviral Activity of Human Surfactant Protein D by Site-Specific Engineering of the Carbohydrate Recognition Domain. Front Immunol (2019) 10:2476. doi: 10.3389/fimmu.2019.02476 
67. Watson A, Phipps MJS, Clark HW, Skylaris C-K, Madsen J. Surfactant Proteins A and D: Trimerized Innate Immunity Proteins With an Affinity for Viral Fusion Proteins. J Innate Immun (2019) 11:13-28. doi: 10.1159/ 000492974

68. Leth-Larsen R, Zhong F, Chow VTK, Holmskov U, Lu J. The SARS Coronavirus Spike Glycoprotein is Selectively Recognized by Lung Surfactant Protein D and Activates Macrophages. Immunobiol (2007) 212:201-11. doi: 10.1016/j.imbio.2006.12.001

69. Madan T, Biswas B, Varghese PM, Subedi R, Pandit H, Idicula-Thomas S, et al. A Recombinant Fragment of Human Surfactant Protein D Binds Spike Protein and Inhibits Infectivity and Replication of SARS-CoV-2 in Clinical Samples. Am J Respir Cell Mol Biol (2021) 65:41-53. doi: 10.1165/rcmb.2021$0005 \mathrm{OC}$

70. Watson A, Madsen J, Clark HW. SP-A and SP-D: Dual Functioning Immune Molecules With Antiviral and Immunomodulatory Properties. Front Immunol (2021) 11:622598. doi: 10.3389/fimmu.2020.622598

71. Hsieh M-H, Beirag N, Murugaiah V, Chou Y-C, Kuo W-S, Kao H-F, et al. Human Surfactant Protein D Binds Spike Protein and Acts as an Entry Inhibitor of SARS-CoV-2 Pseudotyped Viral Particles. Front Immunol (2021) 12:641360. doi: 10.3389/fimmu.2021.641360

72. Alay H, Laloglu E. The Role of Angiopoietin-2 and Surfactant Protein-D Levels in SARS-CoV-2-Related Lung Injury: A Prospective, Observational, Cohort Study. J Med Virol (2021) 93:6008-15. doi: 10.1002/jmv.27184

73. Weiskirchen R. Severity of Coronavirus Disease 2019 (COVID-19): Does Surfactant Matter? Front Microbiol (2020) 11:1905. doi: 10.3389/ fmicb.2020.01905

74. Kerget B, Kerget F, Koçak AO, Kızıltunç A, Araz Ö, Uçar EY, et al. Are Serum Interleukin 6 and Surfactant Protein D Levels Associated With the Clinical Course of COVID-19? Lung (2020) 198:777-84. doi: 10.1007/s00408-02000393-8

75. Saito A, Kuronuma K, Moniwa K, Kodama K, Takahashi S, Takahashi H, et al. Serum Surfactant Protein A and D may be Novel Biomarkers of COVID-19 Pneumonia Severity. Res Square (2020). doi: 10.21203/rs.3.rs-29567/v1

76. Wu YP, Liu ZH, Wei R, Pan SD, Mao NY, Chen B, et al. Elevated Plasma Surfactant Protein D (SP-D) Levels and a Direct Correlation With Anti-Severe Acute Respiratory Syndrome Coronavirus-Specific IgG Antibody in SARS Patients. Scand J Immunol (2009) 69:508-15. doi: 10.1111/j.13653083.2009.02245.x

77. Potere N, Del Buono MG, Mauro AG, Abbate A, Toldo S. Low Density Lipoprotein Receptor-Related Protein-1 in Cardiac Inflammation and Infarct Healing. Front Cardiovasc Med (2019) 6:51. doi: 10.3389/fcvm.2019.00051

78. Ogden CA, deCathelineau A, Hoffmann PR, Bratton D, Ghebrehiwet B, Fadok VA, et al. Clq and Mannose Binding Lectin Engagement of Cell Surface Calreticulin and CD91 Initiates Micropinocytosis and Uptake of Apoptotic Cells. J Exp Med (2001) 194:781-95. doi: 10.1084/jem.194.6.781

79. Cañadas O, Olmeda B, Alonso A, Pérez-Gil J. Lipid-protein and ProteinProtein Interactions in the Pulmonary Surfactant System and Their Role in Lung Homeostasis. Int J Mol Sci (2020) 21:3708. doi: 10.3390/ijms21103708

80. Vandivier RW, Ogden CA, Fadok VA, Hoffman PR, Brown KK, Botto M, et al. Role of Surfactant Proteins A, D, and C1q in the Clearance of Apoptotic Cells In Vivo and In Vitro: Calreticulin and CD91 as a Common Collectin Receptor Complex. J Immunol (2002) 169:3978-86. doi: 10.4049/jimmunol.169.7.3978

81. Andrejeva G, Capoccia BJ, Hiebsch RR, Donio MJ, Darwech IM, Puro RJ, et al. Novel SIRP $\alpha$ Antibodies That Induce Single-Agent Phagocytosis of Tumor Cells While Preserving T Cells. J Immunol (2021) 206:712-21. doi: 10.4049/ jimmunol.2001019

82. Tal MC, Torrez Dulgeroff LB, Myers L, Cham LB, Mayer-Barber KD, Bohrer AC, et al. Upregulation of CD47 is a Host Checkpoint Response to Pathogen Recognition. mBio (2020) 11:e01293-20. doi: 10.1128/mBio.01293-20

83. Sarute N, Cheng H, Yan Z, Salas-Briceno K, Richner J, Rong L, et al. SignalRegulatory Protein Alpha is an Anti-Viral Entry Factor Targeting Viruses Using Endocytic Pathways. PloS Pathog (2021) 17:e1009662. doi: 10.1371/ journal.ppat.1009662

84. McLaughlin K-M, Bojkova D, Bechtel M, Kandler JD, Reus P, Le T, et al. CD47 as a Potential Biomarker for the Early Diagnosis of Severe COVID-19. bioRxiv (2021). doi: 10.1101/2021.03.01.433404

85. Sharif-Askari NS, Sharif-Askari FS, Mdkhana B, Al Heialy S, Alsafar HS, Hamoudi R, et al. Enhanced Expression of Immune Checkpoint Receptors
During SARS-CoV-2 Viral Infection. Mol Ther Methods Clin Dev (2021) 20:109-21. doi: 10.1016/j.omtm.2020.11.002

86. Colmorten KB, Nexoe AB, Sorensen GL. The Dual Role of Surfactant Protein$\mathrm{D}$ in Vascular Inflammation and Development of Cardiovascular Disease. Front Immunol (2019) 10:2264. doi: 10.3389/fimmu.2019.02264

87. Guo CJ, Atochina-Vasserman EN, Abramova E, Foley JP, Zaman A, Crouch E, et al. S-Nitrosylation of Surfactant Protein-D Controls Inflammatory Function. PloS Biol (2008) 6:e266. doi: 10.1371/journal.pbio.0060266

88. Janssen WJ, McPhillips KA, Dickinson MG, Linderman DJ, Morimoto K, Xiao YQ, et al. Surfactant Proteins A and D Suppress Alveolar Macrophage Phagocytosis via Interaction With SIRP $\alpha$. Am J Respir Crit Care Med (2008) 178:158-67. doi: 10.1164/rccm.200711-1661OC

89. McCubbrey AL, Sonstein J, Ames TM, Freeman CM, Curtis JL. Glucocorticoids Relieve Collectin-Driven Suppression of Apoptotic Cell Uptake in Murine Alveolar Macrophages Through Downregulation of SIRPo. J Immunol (2012) 189:112-9. doi: 10.4049/jimmunol.1200984

90. Hortobágyi L, Kierstein S, Krytska K, Zhu X, Das AM, Poulain F, et al. Surfactant Protein D Inhibits TNF- $\alpha$ Production by Macrophages and Dendritic Cells in Mice. J Allergy Clin Immunol (2008) 122:521-8. doi: 10.1016/j.jaci.2008.05.002

91. Gaultier A, Arandjelovic S, Niessen S, Overton CD, Linton MF, Fazio S, et al. Regulation of Tumor Necrosis Factor Receptor-1 and the IKK-NF-kappaB Pathway by LDL Receptor-Related Protein Explains the Antiinflammatory Activity of This Receptor. Blood (2008) 111:5316-25. doi: 10.1182/blood2007-12-127613

92. Hu F, Liang W, Ren Z, Wang G, Ding G. Surfactant Protein D Inhibits Lipopolysaccharide-Induced Monocyte Chemoattractant Protein-1 Expression in Human Renal Tubular Epithelial Cells: Implication for Tubulointerstitial Fibrosis. Clin Exp Immunol (2012) 167:514-22. doi: 10.1111/j.1365-2249.2011.04521.x

93. Gonias SL, Campana WM. LDL Receptor-Related Protein-1. A Regulator of Inflammation in Atherosclerosis, Cancer, and Injury to the Nervous System. Am J Pathol (2014) 184:18-27. doi: 10.1016/j.ajpath.2013.08.029

94. Yancey PG, Blakemore J, Ding L, Fan D, Overton CD, Zhang Y, et al. Macrophage LRP-1 Controls Plaque Cellularity by Regulating Efferocytosis and Akt Activation. Arterioscler Thromb Vasc Biol (2010) 30:787-95. doi: 10.1161/ATVBAHA.109.202051

95. Boucher P, Herz J. Signaling Through LRP1: Protection From Atherosclerosis and Beyond. Biochem Pharmacol (2011) 81:1-5. doi: 10.1016/ j.bcp.2010.09.018

96. May P. The Low-Density Lipoprotein Receptor-Related Protein 1 in Inflammation. Curr Opin Lipidol (2013) 24:134-7. doi: 10.1097/ MOL.0b013e32835e809c

97. Sorensen GL, Madsen J, Kejling K, Tornoe I, Nielsen O, Townsend P, et al. Surfactant Protein D is Proatherogenic in Mice. Am J Physiol Heart Circ Physiol (2006) 290:H2286-94. doi: 10.1152/ajpheart.01105.2005

98. Goettsch C, Rauner M, Sinningen K, Helas S, Al-Fakhri N, Nemeth K, et al. The Osteoclast-Associated Receptor (OSCAR) is a Novel Receptor Regulated by Oxidized Low-Density Lipoprotein in Human Endothelial Cells. Endocrinol (2011) 152:4915-26. doi: 10.1210/en.2011-1282

99. Barrow AD, Palarasah Y, Bugatti M, Holehouse AS, Byers DE, Holtzman MJ, et al. OSCAR is a Receptor for Surfactant Protein D That Activates TNFAlpha Release From Human CCR2+ Inflammatory Monocytes. J Immunol (2015) 194:3317-26. doi: 10.4049/jimmunol.1402289

100. Sorensen GL. Surfactant Protein D is Not So Friendly Outside the LungAggravation of Cardiovascular Disease. Cardiovasc Res (2017) 113:1099-101. doi: $10.1093 / \mathrm{cvr} / \mathrm{cvx} 124$

101. Sorensen GL. Surfactant Protein D in Respiratory and non-Respiratory Diseases. Front Med (2018) 5:18. doi: 10.3389/fmed.2018.00018

102. Snyder GD, Oberley-Deegan RE, Goss KL, Romig-Martin SA, Stoll LL, Snyder JM, et al. Surfactant Protein D is Expressed and Modulates Inflammatory Responses in Human Coronary Artery Smooth Muscle Cells. Am J Physiol Heart Circ Physiol (2008) 294:H2053-9. doi: 10.1152/ ajpheart.91529.2007

103. Lee MY, Sorensen GL, Holmskov U, Vanhoutte PM. The Presence and Activity of SP-D in Porcine Coronary Endothelial Cells Depend on Akt/PI(3) $\mathrm{K}$, Erk and Nitric Oxide and Decrease After Multiple Passaging. Mol Immunol (2008) 46:1050-7. doi: 10.1016/j.molimm.2008.09.027 
104. Sorensen GL, Hoegh SV, Leth-Larsen R, Thomsen TH, Floridon C, Smith K, et al. Multimeric and Trimeric Subunit SP-D are Interconvertible Structures With Distinct Ligand Interaction. Mol Immunol (2009) 46:3060-9. doi: 10.1016/j.molimm.2009.06.005

105. Hirano Y, Choi A, Tsuruta M, Jaw JE, Oh Y, Ngan D, et al. Surfactant Protein-D Deficiency Suppresses Systemic Inflammation and Reduces Atherosclerosis in ApoE Knockout Mice. Cardiovasc Res (2017) 113:120818. doi: $10.1093 / \mathrm{cvr} / \mathrm{cvx} 067$

106. Hill J, Heslop C, Man SF, Frohlich J, Connett JE, Anthonisen NR, et al. Circulating Surfactant Protein-D and the Risk of Cardiovascular Morbidity and Mortality. Eur Heart J (2011) 32:1918-25. doi: 10.1093/eurheartj/ehr124

107. Sluimer JC, Gasc JM, Hamming I, van Goor H, Michaud A, van den Akker LH, et al. Angiotensin-Converting Enzyme 2 (ACE2) Expression and Activity in Human Carotid Atherosclerotic Lesions. J Pathol (2008) 215:273-9. doi: 10.1002/path.2357

108. Poznyak AV, Bezsonov EE, Eid AH, Popkova TV, Nedosugova LV, Starodubova AV, et al. ACE2 is an Adjacent Element of Atherosclerosis and COVID-19 Pathogenesis. Int J Mol Sci (2021) 22:4691. doi: 10.3390/ ijms 22094691

109. Gardai SJ, Xiao Y-Q, Dickinson M, Nick JA, Voelker DR, Greene KE, et al. By Binding SIRP $\alpha$ or Calreticulin/CD91, Lung Collectins Act as Dual Function Surveillance Molecules to Suppress or Enhance Inflammation. Cell (2003) 115:13-23. doi: 10.1016/s0092-8674(03)00758-x

110. dos-Santos D, Salina ACG, Rodrigues TS, Rocha MF, Freitas-Filho EG, Alzamora-Terrel DL, et al. Efferocytosis of SARS-CoV-2-Infected Dying Cells Impairs Macrophage 1 Anti-Inflammatory Programming and Continual Clearance of Apoptotic Cells. medRxiv (2021). doi: 10.1101/ 2021.02.18.21251504

111. Noris M, Benigni A, Remuzzi G. The Case of Complement Activation in COVID-19 Multiorgan Impact. Kidney Int (2020) 98:314-22. doi: 10.1016/ j.kint.2020.05.013

112. Polycarpou A, Howard M, Farrar CA, Greenlaw R, Fanelli G, Wallis R, et al. Rationale for Targeting Complement in COVID-19. EMBO Mol Med (2020) 12:e12642. doi: 10.15252/emmm.202012642

113. Tillett WS, Francis T Jr. Serological Reactions in Pneumonia With a nonProtein Somatic Fraction of Pneumococcus. J Exp Med (1930) 52:561-71. doi: $10.1084 /$ jem.52.4.561

114. Du Clos TW. Function of C-Reactive Protein. Ann Med (2000) 32:274-8. doi: $10.3109 / 07853890009011772$

115. Marnell L, Mold C, Du Clos TW. C-Reactive Protein: Ligands, Receptors and Role in Inflammation. Clin Immunol (2005) 117:104-11. doi: 10.1016/ j.clim.2005.08.004

116. Pepys MB, Hirschfield GM. C-Reactive Protein: A Critical Update. J Clin Invest (2003) 111:1805-12. doi: 10.1172/JCI200318921

117. Hirschfield GM, Pepys MB. C-Reactive Protein and Cardiovascular Disease: New Insights From an Old Molecule. Q J Med (2003) 96:793-807. doi: 10.1093/qjmed/hcg134

118. Boguslawski G, Labarrere CA. The Role of C-Reactive Protein as a Cardiovascular Risk Predictor. Kardiochir Torakochir Pol (2006) 3:16-28. doi: $10.1201 / \mathrm{b} 14635-16$

119. Boncler M, Wu Y, Watala C. The Multiple Faces of C-Reactive ProteinPhysiological and Pathophysiological Implications in Cardiovascular Disease. Molecules (2019) 24:2062. doi: 10.3390/molecules24112062

120. Boguslawski G, McGlynn PW, Potempa LA, Filep JG, Labarrere CA. Conduct Unbecoming: C-Reactive Protein Interactions With a Broad Range of Protein Molecules. J Heart Lung Transplant (2007) 26:705-13. doi: 10.1016/j.healun.2007.04.006

121. Mihlan M, Blom AM, Kupreishvili K, Lauer N, Stelzner K, Bergström F, et al. Monomeric C-Reactive Protein Modulates Classic Complement Activation on Necrotic Cells. FASEB J (2011) 25:4198-210. doi: 10.1096/fj.11-186460

122. Lv J-M, Lü S-Q, Liu Z-P, Zhang J, Gao B-X, Yao Z-Y, et al. Conformational Folding and Disulfide Bonding Drive Distinct Stages of Protein Structure Formation. Sci Rep (2018) 8:1494. doi: 10.1038/s41598-018-20014-y

123. Thiele JR, Zeller J, Bannasch H, Stark GB, Peter K, Eisenhardt SU. Targeting CReactive Protein in Inflammatory Disease by Preventing Conformational Changes. Mediators Inflammation (2015) 2015:372432. doi: 10.1155/2015/372432

124. Black S, Kushner I, Samols D. C-Reactive Protein. J Biol Chem (2004) 279:48487-90. doi: 10.1074/jbc.R400025200
125. Labarrere CA, Zaloga GP. C-Reactive Protein: From Innocent Bystander to Pivotal Mediator of Atherosclerosis. Am J Med (2004) 117:499-507. doi: 10.1016/j.amjmed.2004.03.039

126. Lv J-M, Chen J-Y, Liu Z-P, Yao Z-Y, Wu Y-X, Tong C-S, et al. Cellular Folding Determinants and Conformational Plasticity of Native C-Reactive Protein. Front Immunol (2020) 11:583. doi: 10.3389/fimmu.2020.00583

127. Yasojima K, Schwab C, McGeer EG, McGeer PL. Generation of C-Reactive Protein and Complement Components in Atherosclerotic Plaques. Am J Pathol (2001) 158:1039-51. doi: 10.1016/S0002-9440(10)64051-5

128. Jabs WJ, Theissing E, Nitschke M, Bechtel JFM, Duchrow M, Mohamed S, et al. Local Generation of C-Reactive Protein in Diseased Coronary Artery Venous Bypass Grafts and Normal Vascular Tissue. Circulation (2003) 108:1428-31. doi: 10.1161/01.CIR.0000092184.43176.91

129. Dong Q, Wright JR. Expression of C-Reactive Protein by Alveolar Macrophages. J Immunol (1996) 156:4815-20.

130. Diehl EE, Haines GKIII, Radosevich JA, Potempa LA. Immunohistochemical Localization of Modified C-Reactive Protein Antigen in Normal Vascular Tissue. Am J Med Sci (2000) 319:79-83. doi: 10.1097/00000441-20000200000002

131. Jabs WJ, Lögering BA, Gerke P, Kreft B, Wolber E-M, Klinger MHF, et al. The Kidney as a Second Site of Human C-Reactive Protein Formation In Vivo. Eur J Immunol (2003) 33:152-61. doi: 10.1002/immu.200390018

132. Gould JM, Weiser JN. Expression of C-Reactive Protein in the Human Respiratory Tract. Infect Immun (2001) 69:1747-54. doi: 10.1086/341658

133. Agassandian M, Shurin GV, Ma Y, Shurin MR. C-Reactive Protein and Lung Diseases. Int J Biochem Cell Biol (2014) 53:77-88. doi: 10.1016/ j.biocel.2014.05.016

134. Yasojima K, Schwab C, McGeer EG, McGeer PL. Human Neurons Generate C-Reactive Protein and Amyloid P: Upregulation in Alzheimer's Disease. Brain Res (2000) 887:80-9. doi: 10.1016/S0006-8993(00)02970-X

135. Jialal I, Devaraj S, Venugopal SK. C-Reactive Protein: Risk Marker or Mediator in Atherothrombosis? Hypertension (2004) 44:6-11. doi: 10.1161/01.HYP.0000130484.20501.df

136. Morrison DK. MAP Kinase Pathways. Cold Spring Harb Perspect Biol (2012) 4:a011254. doi: 10.1101/cshperspect.a011254

137. Zhao M, Liu Y, Wang X, New L, Han J, Brunk UT. Activation of the P38 MAP Kinase Pathway is Required for Foam Cell Formation From Macrophages Exposed to Oxidized LDL. APMIS (2002) 110:458-68. doi: 10.1034/j.1600-0463.2002.100604.x

138. Thompson D, Pepys MB, Wood SP. The Physiological Structure of Human C-Reactive Protein and its Complex With Phosphocholine. Structure (1999) 7:169-77. doi: 10.1016/S0969-2126(99)80023-9

139. Chang M-K, Binder CJ, Torzewski M, Witztum JL. C-Reactive Protein Binds to Both Oxidized LDL and Apoptotic Cells Through Recognition of a Common Ligand: Phosphorylcholine of Oxidized Phospholipids. Proc Natl Acad Sci USA (2002) 99:13043-8. doi: 10.1073/pnas.192399699

140. van Tits L, de Graaf J, Toenhake H, van Heerde W, Stalenhoef A. C-Reactive Protein and Annexin A5 Bind to Distinct Sites of Negatively Charged Phospholipids Present in Oxidized Low-Density Lipoprotein. Arterioscler Thromb Vasc Biol (2005) 25:717-22. doi: 10.1161/01.ATV.0000157979.51673.2c

141. Momtazi-Borojeni AA, Ayati SH, Jaafari MR, Sahebkar A. A Simple and Rapid-Acting Approach for the Reduction of C-Reactive Protein. BioMed Pharmacother (2019) 109:2305-8. doi: 10.1016/j.biopha.2018.11.125

142. Agrawal A, Simpson MJ, Black S, Carey MP, Samols D. A C-Reactive Protein Mutant That Does Not Bind to Phosphocholine and Pneumococcal CPolysaccharide. J Immunol (2002) 169:3217-22. doi: 10.4049/ jimmunol.169.6.3217

143. Black S, Agrawal A, Samols D. The Phosphocholine and the PolycationBinding Sites on Rabbit C-Reactive Protein are Structurally and Functionally Distinct. Mol Immunol (2003) 39:1045-54. doi: 10.1016/s0161-5890(03) 00031-2

144. Haapasalo K, Meri S. Regulation of the Complement System by Pentraxins. Front Immunol (2019) 10:1750. doi: 10.3389/fimmu.2019.01750

145. Williams RD, Moran JA, Fryer AA, Littlejohn JR, Williams HM, Greenhough TJ, et al. Monomeric C-Reactive Protein in Serum With Markedly Elevated CRP Levels Shares Common Calcium-Dependent Ligand Binding Properties With an In Vitro Dissociated Form of C-Reactive Protein. Front Immunol (2020) 11:115. doi: 10.3389/fimmu.2020.00115 
146. Trial J, Cieslik KA, Entman ML. Phosphocholine-Containing Ligands Direct CRP Induction of M2 Macrophage Polarization Independent of T Cell Polarization: Implication for Chronic Inflammatory States. Immun Inflammation Dis (2016) 4:274-88. doi: 10.1002/iid3.112

147. Wang J, Tang B, Liu X, Wu X, Wang H, Xu D, et al. Increased Monomeric CRP Levels in Acute Myocardial Infarction: A Possible New and Specific Biomarker for Diagnosis and Severity Assessment of Disease. Atherosclerosis (2015) 239:343-9. doi: 10.1016/j.atherosclerosis.2015.01.024

148. Zhang L, Li HY, Li W, Shen ZY, Wang YD, Ji SR, et al. An ELISA Assay for Quantifying Monomeric C-Reactive Protein in Plasma. Front Immunol (2018) 9:511. doi: 10.3389/fimmu.2018.00511

149. Eisenhardt SU, Thiele JR, Bannasch H, Stark GB, Peter K. C-Reactive Protein. How Conformational Changes Influence Inflammatory Properties. Cell Cycle (2009) 8:3885-92. doi: 10.4161/cc.8.23.10068

150. Thiele JR, Habersberger J, Braig D, Schmidt Y, Goerendt K, Maurer V, et al. Dissociation of Pentameric to Monomeric C-Reactive Protein Localizes and Aggravates Inflammation. In Vivo Proof of a Powerful Proinflammatory Mechanism and a New Anti-Inflammatory Strategy. Circulation (2014) 130:35-50. doi: 10.1161/CIRCULATIONAHA.113.007124

151. Li H-Y, Wang J, Wu Y-X, Zhang L, Liu Z-P, Filep JG, et al. Topological Localization of Monomeric C-Reactive Protein Determines Proinflammatory Endothelial Cell Responses. J Biol Chem (2014) 289:14283-90. doi: 10.1074/ jbc.M114.555318

152. Molins B, Peña E, Vilahur G, Mendieta C, Slevin M, Badimon L. C-Reactive Protein Isoforms Differ in Their Effects on Thrombus Growth. Arterioscler Thromb Vasc Biol (2008) 28:2239-46. doi: 10.1161/ATVBAHA.108.174359

153. Li R, Ren M, Luo M, Chen N, Zhang Z, Luo B, et al. Monomeric C-Reactive Protein Alters Fibrin Clot Properties on Endothelial Cells. Thromb Res (2012) 129:e251-6. doi: 10.1016/j.thromres.2012.03.014

154. Badimon L, Peña E, Arderiu G, Padró T, Slevin M, Vilahur G, et al. CReactive Protein in Atherothrombosis and Angiogenesis. Front Immunol (2018) 9:430. doi: 10.3389/fimmu.2018.00430

155. Eisenhardt SU, Habersberger J, Peter K. Monomeric C-Reactive Protein Generation on Activated Platelets: The Missing Link Between Inflammation and Atherothrombotic Risk. Trends Cardiovasc Med (2009) 19:232-7. doi: $10.1016 /$ j.tcm.2010.02.002

156. Eisenhardt SU, Habersberger J, Murphy A, Chen Y-C, Woollard KJ, Bassler N, et al. Dissociation of Pentameric to Monomeric C-Reactive Protein on Activated Platelets Localizes Inflammation to Atherosclerotic Plaques. Circ Res (2009) 105:128-37. doi: 10.1161/CIRCRESAHA.108.190611

157. Ji S-R, Wu Y, Potempa LA, Liang Y-H, Zhao J. Effect of Modified C-Reactive Protein on Complement Activation. A Possible Complement Regulatory Role of Modified or Monomeric C-Reactive Protein in Atherosclerotic Lesions. Arterioscler Thromb Vasc Biol (2006) 26:935-41. doi: 10.1161/ 01.ATV.0000206211.21895.73

158. Braig D, Kaiser B, Thiele JR, Bannasch H, Peter K, Stark GB, et al. A Conformational Change of C-Reactive Protein in Burn Wounds Unmasks its Proinflammatory Properties. Int Immunol (2014) 26:467-78. doi: 10.1093/ intimm/dxu056

159. Khreiss T, József L, Hossain S, Chan JSD, Potempa LA, Filep JG. Loss of Pentameric Symmetry of C-Reactive Protein is Associated With Delayed Apoptosis of Human Neutrophils. J Biol Chem (2002) 277:40775-81. doi: $10.1074 /$ jbc.M205378200

160. Ji SR, Wu Y, Potempa LA, Sheng FL, Lu W, Zhao J. Cell Membranes and Liposomes Dissociate C-Reactive Protein (CRP) to Form a New, Biologically Active Structural Intermediate mCRPm. FASEB J (2007) 21:284-94. doi: 10.1096/fj.06-6722com

161. Sproston NR, Ashworth JJ. Role of C-Reactive Protein at Sites of Inflammation and Infection. Front Immunol (2018) 9:754. doi: 10.3389/ fimmu.2018.00754

162. Zouki C, Haas B, Chan JSD, Potempa LA, Filep JG. Loss of Pentameric Symmetry of C-Reactive Protein is Associated With Promotion of Neutrophil-Endothelial Cell Adhesion. J Immunol (2001) 167:5355-61. doi: 10.4049/jimmunol.167.9.5355

163. Griselli M, Herbert J, Hutchinson WL, Taylor KM, Sohail M, Krausz T, et al. C-Reactive Protein and Complement are Important Mediators of Tissue Damage in Acute Myocardial Infarction. J Exp Med (1999) 190:1733-40. doi: $10.1084 /$ jem.190.12.1733
164. Torzewski M, Rist C, Mortensen RF, Zwaka TP, Bienek M, Waltenberger J, et al. C-Reactive Protein in the Arterial Intima. Role of C-Reactive Protein Receptor-Dependent Monocyte Recruitment in Atherogenesis. Arterioscler Thromb Vasc Biol (2000) 20:2094-9. doi: 10.1161/01.atv.20.9.2094

165. Zwaka TP, Hombach V, Torzewski J. C-Reactive Protein-Mediated Low Density Lipoprotein Uptake by Macrophages. Implications for Atherosclerosis. Circulation (2001) 103:1194-7. doi: 10.1161/ 01.CIR.103.9.1194

166. Li S-H, Szmitko PE, Weisel RD, Wang C-H, Fedak PWM, Li R-K, et al. CReactive Protein Upregulates Complement-Inhibitory Factors in Endothelial Cells. Circulation (2004) 109:833-6. doi: 10.1161/01.CIR.0000117087.27524.0E

167. Gershov D, Kim S, Brot N, Elkon KB. C-Reactive Protein Binds to Apoptotic Cells, Protects the Cells From Assembly of the Terminal Complement Components, and Sustains an Antiinflammatory Innate Immune Response: Implications for Systemic Autoimmunity. J Exp Med (2000) 192:1353-63. doi: 10.1084/jem.192.9.1353

168. Zouki C, Beauchamp M, Baron C, Filep J. Prevention of In Vitro Neutrophil Adhesion to Endothelial Cells Through Shedding of L-Selectin by C-Reactive Protein and Peptides Derived From C-Reactive Protein. J Clin Invest (1997) 100:522-9. doi: 10.1172/JCI119561

169. Crowell RE, Du Clos TW, Montoya G, Heaphy E, Mold C. C-Reactive Protein Receptors on the Human Monocytic Cell Line U-937. Evidence for Additional Binding to FcyRI. J Immunol (1991) 147:3445-51.

170. Marnell LL, Mold C, Volzer MA, Burlingame RW, Du Clos TW. C-Reactive Protein Binds to FcyRI in Transfected COS Cells. J Immunol (1995) 155:2185-93.

171. Bharadwaj D, Stein M-P, Volzer M, Mold C, Du Clos TW. The Major Receptor for C-Reactive Protein on Leukocytes Is Fc $\gamma$ Receptor II. J Exp Med (1999) 190:585-90. doi: 10.1084/jem.190.4.585

172. Stein M-P, Edberg JC, Kimberly RP, Mangan EK, Bharadwaj D, Mold C, et al. CReactive Protein Binding to FcyRIIa on Human Monocytes and Neutrophils is Allele-Specific. J Clin Invest (2000) 105:369-76. doi: 10.1172/JCI7817

173. Lu J, Marnell LL, Marjon KD, Mold C, Du Clos TW, Sun PD. Structural Recognition and Functional Activation of Fc $\gamma$ R by Innate Pentraxins. Nature (2008) 456:989-92. doi: 10.1038/nature07468

174. Peisajovich A, Marnell L, Mold C, Du Clos TW. C-reactive Protein at the Interface Between Innate Immunity and Inflammation. Expert Rev Clin Immunol (2008) 4:379-90. doi: 10.1586/1744666X.4.3.379

175. Tron K, Manolov DE, Röcker C, Kächele M, Torzewski J, Nienhaus GU. CReactive Protein Specifically Binds to Fcy Receptor Type I on a MacrophageLike Cell Line. Eur J Immunol (2008) 38:1414-22. doi: 10.1002/eji.200738002

176. Rhodes B, Fūrnrohr BG, Vyse TJ. C-Reactive Protein in Rheumatology: Biology and Genetics. Nat Rev Rheumatol (2011) 7:282-9. doi: 10.1038/ nrrheum.2011.37

177. Lu J, Mold C, Du Clos TW, Sun PD. Pentraxins and Fc Receptor-Mediated Immune Responses. Front Immunol (2018) 9:2607. doi: 10.3389/ fimmu.2018.02607

178. Newling M, Sritharan L, van der Ham AJ, Hoepel W, Fiechter RH, de Boer L, et al. C-Reactive Protein Promotes Inflammation Through Fc $\gamma \mathrm{R}$-Induced Glycolytic Reprogramming of Human Macrophages. J Immunol (2019) 203:225-35. doi: 10.4049/jimmunol.1900172

179. Lu J, Marjon KD, Marnell LL, Wang R, Mold C, Du Clos TW, et al. Recognition and Functional Activation of the Human IgA Receptor (FcoRI) by C-Reactive Protein. Proc Natl Acad Sci USA (2011) 108:49749. doi: 10.1073/pnas.1018369108

180. Mold C, Baca R, Du Clos TW. Serum Amyloid P Component and C-Reactive Protein Opsonize Apoptotic Cells for Phagocytosis Through Fc $\gamma$ Receptors. J Autoimmun (2002) 19:147-54. doi: 10.1006/jaut.2002.0615

181. McFadyen JD, Kiefer J, Braig D, Loseff-Silver J, Potempa LA, Eisenhardt SU, et al. Dissociation of C-Reactive Protein Localizes and Amplifies Inflammation: Evidence for a Direct Biological Role of C-Reactive Protein and its Conformational Changes. Front Immunol (2018) 9:1351. doi: 10.3389/fimmu.2018.01351

182. Heuertz RM, Schneider GP, Potempa LA, Webster RO. Native and Modified C-Reactive Protein Bind Different Receptors on Human Neutrophils. Int $J$ Biochem Cell Biol (2005) 37:320-35. doi: 10.1016/j.biocel.2004.07.002

183. Khreiss T, József L, Potempa LA, Filep JG. Loss of Pentameric Symmetry in C-Reactive Protein Induces Interleukin-8 Secretion Through Peroxynitrite 
Signaling in Human Neutrophils. Circ Res (2005) 97:690-7. doi: 10.1161/ 01.RES.0000183881.11739.CB

184. Khreiss T, József L, Potempa LA, Filep JG. Conformational Rearrangement in C-Reactive Protein is Required for Proinflammatory Actions on Human Endothelial Cells. Circulation (2004) 109:2016-22. doi: 10.1161/ 01.CIR.0000125527.41598.68

185. Bodman-Smith KB, Gregory RE, Harrison PT, Raynes JG. FcyRIIa Expression With FcyRI Results in C-Reactive Protein and IgG-Mediated Phagocytosis. J Leukoc Biol (2004) 75:1029-35. doi: 10.1189/jlb.0703306

186. Fujita M, Takada YK, Izumiya Y, Takada Y. The Binding of Monomeric CReactive Protein (mCRP) to Integrins $\alpha v \beta 3$ and $\alpha 4 \beta 1$ is Related to its ProInflammatory Action. PloS One (2014) 9:e93738. doi: 10.1371/ journal.pone.0093738

187. Lv J-M, Wang M-Y. In Vitro Generation and Bioactivity Evaluation of CReactive Protein Intermediate. PloS One (2018) 13:e0198375. doi: 10.1371/ journal.pone. 0198375

188. Singh SK, Agrawal A. Functionality of C-Reactive Protein for Atheroprotection. Front Immunol (2019) 10:1655. doi: 10.3389/fimmu.2019.01655

189. Agrawal A, Gang TB, Rusiñol AE. Recognition Functions of Pentameric CReactive Protein in Cardiovascular Disease. Mediators Inflamm (2014) 319215. doi: 10.1155/2014/319215

190. Braig D, Nero TL, Koch H-G, Kaiser B, Wang X, Thiele JR, et al. Transitional Changes in the CRP Structure Lead to the Exposure of Proinflammatory Binding Sites. Nat Commun (2017) 8:14188. doi: 10.1038/ncomms14188

191. Wu J, Stevenson MJ, Brown JM, Grunz EA, Strawn TL, Fay WP. C-Reactive Protein Enhances Tissue Factor Expression by Vascular Smooth Muscle Cells. Mechanisms and In Vivo Significance. Arterioscler Thromb Vasc Biol (2008) 28:698-704. doi: 10.1161/ATVBAHA.107.160903

192. Mackman N, Taubman MB. Does Tissue Factor Expression by Vascular Smooth Muscle Cells Provide a Link Between C-Reactive Protein and Cardiovascular Disease? Arterioscler Thromb Vasc Biol (2008) 28:601-3. doi: 10.1161/ATVBAHA.108.165050

193. Ullah N, Ma F-R, Han J, Liu X-L, Fu Y, Liu Y-T, et al. Monomeric C-Reactive Protein Regulates Fibronectin Mediated Monocyte Adhesion. Mol Immunol (2020) 117:122-30. doi: 10.1016/j.molimm.2019.10.013

194. Schmitz G, Grandl M. Role of Redox Regulation and Lipid Rafts in Macrophages During Ox-LDL-mediated Foam Cell Formation. Antioxid Redox Signal (2007) 9:1499-518. doi: 10.1089/ars.2007.1663

195. Zhao XQ, Zhang MW, Wang F, Zhao YX, Li JJ, Wang XP, et al. CRP Enhances Soluble LOX-1 Release From Macrophages by Activating TNF- $\alpha$ Converting Enzyme. J Lipid Res (2011) 52:923-33. doi: 10.1194/jlr.M015156

196. Salazar J, Martínez MS, Chávez-Castillo M, Núñez V, Añez R, Torres Y, et al. C-Reactive Protein: An in-Depth Look Into Structure, Function, and Regulation. Int Sch Res Notices (2014), 653045. doi: 10.1155/2014/653045

197. Gao R, Wang L, Bai T, Zhang Y, Bo H, Shu Y. C-Reactive Protein Mediating Immunopathological Lesions: A Potential Treatment Option for Severe Influenza A Diseases. EBioMedicine (2017) 22:133-42. doi: 10.1016/ j.ebiom.2017.07.010

198. Haran JP, Suner S, Gardiner F. Correlation of C-Reactive Protein to Severity of Symptoms in Acute Influenza A Infection. J Emerg Trauma Shock (2012) 5:149-52. doi: 10.4103/0974-2700.96484

199. Shen Z, Chen Z, Li X, Xu L, Guan W, Cao Y, et al. Host Immunological Response and Factors Associated With Clinical Outcome in Patients With the Novel Influenza A H7N9 Infection. Clin Microbiol Infect (2014) 20:493500. doi: 10.1111/1469-0691.12505

200. Tekin S, Keske S, Alan S, Batirel A, Karacoc C, Tasdelen-Fisgin N, et al. Predictors of Fatality in Influenza A Virus Subtype Infections Among Inpatients in the 2015-2016 Season. Int J Infect Dis (2019) 81:6-9. doi: 10.1016/j.ijid.2019.01.005

201. Perez L. Acute Phase Protein Response to Viral Infection and Vaccination. Arch Biochem Biophys (2019) 671:196-202. doi: 10.1016/j.abb.2019.07.013

202. Lee EE, Song K-H, Hwang W, Ham SY, Jeong H, Kim J-H, et al. Pattern of Inflammatory Immune Response Determines the Clinical Course and Outcome of COVID-19: Unbiased Clustering Analysis. Sci Rep (2021) 11:8080. doi: 10.1038/s41598-021-87668-Z

203. Chen W, Zheng KI, Liu S, Yan Z, Xu C, Qiao Z. Plasma CRP Level is Positively Associated With the Severity of COVID-19. Ann Clin Microbiol Antimicrob (2020) 19:18. doi: 10.1186/s12941-020-00362-2
204. Fendl B, Weiss R, Eichhorn T, Linsberger I, Afonyushkin T, Puhm F, et al. Extracellular Vesicles are Associated With C-reactive Protein in Sepsis. Sci Rep (2021) 11:6996. doi: 10.1038/s41598-021-86489-4

205. Potempa LA, Rajab IM, Hart PC, Bordon J, Fernandez-Botran R. Insights Into the Use of C-Reactive Protein as a Diagnostic Index of Disease Severity in COVID-19 Infections. Am J Trop Med Hyg (2020) 103:561-3. doi: 10.4269/ajtmh.20-0473

206. Mosquera-Sulbaran JA, Pedreañez A, Carrero Y, Callejas D. C-Reactive Protein as an Effector Molecule in Covid-19 Pathogenesis. Rev Med Virol (2021) e2221. doi: 10.1002/rmv.2221

207. Dufort EM, Koumans EH, Chow EJ, Rosenthal EM, Muse A, Rowlands J, et al. For the New York State and Centers for Disease Control and Prevention Multisystem Inflammatory Syndrome in Children Investigation Team. Multisystem Inflammatory Syndrome in Children in New York State. N Engl J Med (2020) 383:347-58. doi: 10.1056/NEJMoa2021756

208. Manson JJ, Crooks C, Naja M, Ledlie A, Goulden B, Liddle T, et al. COVID19-Associated Hyperinflammation and Escalation of Patient Care: A Retrospective Longitudinal Cohort Study. Lancet Rheumatol (2020) 2: e594-602. doi: 10.1016/S2665-9913(20)30275-7

209. Davies P, Evans C, Kanthimathinathan HK, Lillie J, Brierley J, Waters G, et al. Intensive Care Admissions of Children With Paediatric Inflammatory Multisystem Syndrome Temporally Associated With SARS-CoV-2 (PIMSTS) in the UK: A Multicenter Observational Study. Lancet Child Adolesc Health (2020) 4:669-77. doi: 10.1016/S2352-4642(20)30215-7

210. Zhang J, Yu M, Tong S, Liu L-Y, Tang L-V. Predictive Factors for Disease Progression in Hospitalized Patients With Coronavirus Disease 2019 in Wuhan, China. J Clin Virol (2020) 127:104392. doi: 10.1016/j.jcv.2020. 104392

211. Clarke P, Tyler KL. Apoptosis in Animal Models of Virus-Induced Disease. Nat Rev Microbiol (2009) 7:144-55. doi: 10.1038/nrmicro2071

212. Kaminskyy V, Zhivotovsky B. To Kill or be Killed: How Viruses Interact With the Cell Death Machinery. J Intern Med (2010) 267:473-82. doi: 10.1111/j.1365-2796.2010.02222.x

213. Nainu F, Shiratsuchi A, Nakanishi Y. Induction of Apoptosis and Subsequent Phagocytosis of Virus-Infected Cells as an Antiviral Mechanism. Front Immunol (2017) 8:1220. doi: 10.3389/fimmu.2017.01220

214. Gould JM, Weiser JN. The Inhibitory Effect of C-Reactive Protein on Bacterial Phosphorylcholine Platelet-Activating Factor Receptor-Mediated Adherence is Blocked by Surfactant. J Infect Dis (2002) 186:361-71. doi: $10.1086 / 341658$

215. Wright JR. Immunomodulatory Functions of Surfactant. Physiol Rev (1997) 77:931-62. doi: 10.1152/physrev.1997.77.4.931

216. Heidelberger M, Pedersen KO. The Molecular Weight of Antibodies". J Exp Med (1937) 65:393-414. doi: 10.1084/jem.65.3.393

217. Kabat EA, Pedersen KO. The Molecular Weight of Antibodies. Science (1938) 87:372. doi: 10.1126/science.87.2260.372

218. Kabat EA. The Molecular Weight of Antibodies. J Exp Med (1939) 69:10318. doi: $10.1084 /$ jem.69.1.103

219. Boes M. Role of Natural and Immune IgM Antibodies in Immune Responses. Mol Immunol (2000) 37:1141-9. doi: 10.1016/s0161-5890(01)00025-6

220. Gong S, Ruprecht RM. Immunoglobulin M: An Ancient Antiviral Weapon Rediscovered. Front Immunol (2020) 11:1943. doi: 10.3389/fimmu.2020.01943

221. Hiramoto E, Tsutsumi A, Suzuki R, Matsuoka S, Arai S, Kikkawa M, et al. The IgM Pentamer is an Asymmetric Pentagon With an Open Groove That Binds the AIM Protein. Sci Adv (2018) 4:eaau1199. doi: 10.1126/ sciadv.aau1199

222. Chen Y, Park Y-B, Patel E, Silverman GJ. IgM Antibodies to ApoptosisAssociated Determinants Recruit C1q and Enhance Dendritic Cell Phagocytosis of Apoptotic Cells. J Immunol (2009) 182:6031-43. doi: 10.4049/jimmunol.0804191

223. Klimovich VB. IgM and its Receptors: Structural and Functional Aspects. Biochem (Moscow) (2011) 76:534-49. doi: 10.1134/S0006297911050038

224. Racine R, Winslow GM. IgM in Microbial Infections: Taken for Granted? Immunol Lett (2009) 125:79-85. doi: 10.1016/j.imlet.2009.06.003

225. Baumgarth N, Herman OC, Jager GC, Brown LE, Herzenberg LA, Chen J. B1 and B-2 Cell- Derived Immunoglobulin M Antibodies are Nonredundant Components of the Protective Response to Influenza Virus Infection. J Exp Med (2000) 192:271-80. doi: 10.1084/jem.192.2.271 
226. Savage HP, Baumgarth N. Characteristics of Natural Antibody-Secreting Cells. Ann NY Acad Sci (2015) 1362:132-42. doi: 10.1111/nyas.12799

227. Ehrenstein MR, Notley CA. The Importance of Natural IgM: Scavenger, Protector and Regulator. Nat Rev Immunol (2010) 10:778-86. doi: 10.1038/ nri2849

228. Gunti S, Notkins AL. Polyreactive Antibodies: Function and Quantification. J Infect Dis (2015) 212(Suppl 1):S42-6. doi: 10.1093/infdis/jiu512

229. Baumgarth N. A Hard(Y) Look at B-1 Cell Development and Function. J Immunol (2017) 199:3387-94. doi: 10.4049/jimmunol.1700943

230. Griffin DO, Holodick NE, Rothstein TL. Human B1 Cells in Umbilical Cord and Adult Peripheral Blood Express the Novel Phenotype CD20+ CD27+ CD43+ CD70-. J Exp Med (2011) 208:67-80. doi: 10.1084/jem.20101499

231. Griffin DO, Rothstein TL. Human B1 Cell Frequency: Isolation and Analysis of Human B1 Cells. Front Immunol (2012) 3:122. doi: 10.3389/fimmu.2012.00122

232. Griffin DO, Rothstein TL. Human "Orchestrator" CD11b(+) B1 Cells Spontaneously Secrete Interleukin-10 and Regulate T-Cell Activity. Mol Med (2012) 18:1003-8. doi: 10.2119/molmed.2012.00203

233. Wang X, Ma K, Chen M, Ko K-H, Zheng B-J, Lu L. IL-17A Promotes Pulmonary B-1a Cell Differentiation via Induction of Blimp-1 Expression During Influenza Virus Infection. PloS Pathog (2016) 12:e1005367. doi: 10.1371/journal.ppat.1005367

234. Baumgarth N, Herman OC, Jager GC, Brown L, Herzenberg LA, Herzenberg LA. Innate and Acquired Humoral Immunities to Influenza Virus are Mediated by Distinct Arms of the Immune System. Proc Natl Acad Sci USA (1999) 96:2250-5. doi: 10.1073/pnas.96.5.2250

235. Baumgarth N. The Double Life of a B-1 Cell: Self-Reactivity Selects for Protective Effector Functions. Nat Rev Immunol (2011) 11:34-46. doi: 10.1038/nri2901

236. Brändlein S, Vollmers HP. Natural IgM Antibodies, the Ignored Weapons in Tumour Immunity. Histol Histopathol (2004) 19:897-905. doi: 10.14670/HH-19.897

237. Lobo ED, Hansen RJ, Balthasar JP. Antibody Pharmacokinetics and Pharmacodynamics. J Pharm Sci (2004) 93:2645-68. doi: 10.1002/jps.20178

238. Gonzalez-Quintela A, Alende R, Gude F, Campos J, Rey J, Meijide LM, et al. Serum Levels of Immunoglobulins (IgG, IgA, IgM) in a General Adult Population and Their Relationship With Alcohol Consumption, Smoking and Common Metabolic Abnormalities. Clin Exp Immunol (2008) 151:4250. doi: 10.1111/j.1365-2249.2007.03545.x

239. German EL, Al-Hakim B, Mitsi E, Pennington SH, Gritzfeld JF, HyderWright $\mathrm{AD}$, et al. Anti-Protein Immunoglobulin M Responses to Pneumococcus are Not Associated With Aging. Pneumonia (2018) 10:5. doi: 10.1186/s41479-018-0048-3

240. Wang Z, Li H, Li J, Yang C, Guo X, Hu Z, et al. Elevated Serum IgM Levels Indicate Poor Outcome in Patients With Coronavirus Disease 2019 Pneumonia: A Retrospective Case-Control Study. medRxiv (2020). doi: 10.1101/2020.03.22.20041285

241. Ku Z, Xie X, Hinton PR, Liu X, Ye X, Muruato AE, et al. Nasal Delivery of an IgM Offers Broad Protection From SARS-CoV-2 Variants. Nature (2021) 595:718-23. doi: 10.1038/s41586-021-03673-2

242. Costela-Ruiz VJ, Illescas-Montes R, Puerta-Puerta JM, Ruiz C, MelguizoRodríguez L. SARS-CoV-2 Infection: The Role of Cytokines in COVID-19 Disease. Cytokine Growth Factor Rev (2020) 54:62-75. doi: 10.1016/ j.cytogfr.2020.06.001

243. Fajgenbaum DC, June CH. Cytokine Storm. N Engl J Med (2020) 383:225573. doi: 10.1056/NEJMra2026131

244. Schett G, Manger B, Simon D, Caporali R. COVID-19 Revisiting Inflammatory Pathways of Arthritis. Nat Rev Rheumatol (2020) 16:46570. doi: 10.1038/s41584-020-0451-z

245. Arango Duque G, Descoteaux A. Macrophage Cytokines: Involvement in Immunity and Infectious Diseases. Front Immunol (2014) 5:491. doi: 10.3389/fimmu.2014.00491

246. Merad M, Martin JC. Pathological Inflammation in Patients With COVID19: A Key Role for Monocytes and Macrophages. Nat Rev Immunol (2020) 20:355-62. doi: 10.1038/s41577-020-0331-4

247. Zuo Y, Yalavarthi S, Shi H, Gockman K, Zuo M, Madison JA, et al. Neutrophil Extracellular Traps in COVID-19. JCI Insight (2020) 5: e138999. doi: 10.1172/jci.insight.138999

248. Veras FP, Cornejo Pontelli M, Silva CM, Toller-Kawahisa JE, de Lima M, Carvalho Nascimento D, et al. SARS-CoV-2-Triggered Neutrophil
Extracellular Traps Mediate COVID-19 Pathology. J Exp Med (2020) 217: e20201129. doi: 10.1084/jem.20201129

249. Arcanjo A, Logullo J, Barreto Menezes CC, de Souza Carvalho Giangiarulo TC, Carneiro dos Reis M, Menezes Migliani de Castro G, et al. The Emerging Role of Neutrophil Extracellular Traps in Severe Acute Respiratory Syndrome Coronavirus 2 (COVID-19). Sci Rep (2020) 10:19630. doi: 10.1038/s41598-020-76781-0

250. Middleton EA, He X-Y, Denorme F, Campbell RA, Ng D, Salvatore SP, et al. Neutrophil Extracellular Traps Contribute to Immunothrombosis in COVID-19 Acute Respiratory Distress Syndrome. Blood (2020) 136:116979. doi: 10.1182/blood.2020007008

251. Ondracek AS, Lang IM. Neutrophil Extracellular Traps as Prognostic Markers in COVID-19. A Welcome Piece to the Puzzle. Arterioscler Thromb Vasc Biol (2021) 41:995-8. doi: 10.1161/ATVBAHA.120.315633

252. Borges L, Pithon-Curi TC, Curi R, Hatanaka E. COVID-19 and Neutrophils: The Relationship Between Hyperinflammation and Neutrophil Extracellular Traps. Mediators Inflamm (2020) 8829674. doi: 10.1155/2020/8829674

253. Leppkes M, Knopf J, Naschberger E, Lindemann A, Singh J, Herrmann I, et al. Vascular Occlusion by Neutrophil Extracellular Traps in COVID-19. EBioMedicine (2020) 58:102925. doi: 10.1016/j.ebiom.2020.102925

254. de Buhr N, von Köckritz-Blickwede M. The Balance of Neutrophil Extracellular Trap Formation and Nuclease Degradation: An Unknown Role of Bacterial Coinfections in COVID-19 Patients? mBio (2021) 12: e03304-20. doi: 10.1128/mBio.03304-20

255. Blasco A, Coronado M-J, Hernández-Terciado F, Martín P, Royuela A, Ramil E, et al. Assessment of Neutrophil Extracellular Traps in Coronary Thrombus of a Case Series of Patients With COVID-19 and Myocardial Infarction. JAMA Cardiol (2021) 6:469-74. doi: 10.1001/jamacardio.2020.7308

256. Ng H, Havervall S, Rosell A, Aguilera K, Parv K, von Meijenfeldt FA, et al. Circulating Markers of Neutrophil Extracellular Traps Are of Prognostic Value in Patients With COVID-19. Arterioscler Thromb Vasc Biol (2021) 41:988-94. doi: 10.1161/ATVBAHA.120.315267

257. Yousefi S, Simon D, Stojkov D, Karsonova A, Karaulov A, Simon H-U. In Vivo Evidence for Extracellular DNA Trap Formation. Cell Death Dis (2020) 11:300. doi: 10.1038/s41419-020-2497-x

258. Mukherjee M, Lacy P, Ueki S. Eosinophil Extracellular Traps and Inflammatory Pathologies-Untangling the Web! Front Immunol (2018) 9:2763. doi: 10.3389/fimmu.2018.02763

259. Schorn C, Janko C, Latzko M, Chaurio R, Schett G, Herrmann M. Monosodium Urate Crystals Induce Extracellular DNA Traps in Neutrophils, Eosinophils, and Basophils But Not in Mononuclear Cells. Front Immunol (2012) 3:277. doi: 10.3389/fimmu.2012.00277

260. Rodrigues PRS, Alrubayyi A, Pring E, Bart VMT, Jones R, Coveney C, et al. Innate Immunology in COVID-19-a Living Review. Part II: Dysregulated Inflammation Drives Immunopathology. Oxford Open Immunol (2020) 1: iqaa005. doi: 10.1093/oxfimm/iqaa005

261. Morshed M, Hlushchuk R, Simon D, Walls AF, Obata-Ninomiya K, Karasuyama H, et al. NADPH Oxidase-Independent Formation of Extracellular DNA Traps by Basophils. J Immunol (2014) 192:5314-23. doi: 10.4049/jimmunol.1303418

262. Möllerherm H, von Köckritz-Blickwede M, Branitzki-Heinemann K. Antimicrobial Activity of Mast Cells: Role and Relevance of Extracellular DNA Traps. Front Immunol (2016) 7:265. doi: 10.3389/ fimmu.2016.00265

263. Pertiwi KR, de Boer OJ, Mackaaij C, Pabittei DR, de Winter RJ, Li X, et al. Extracellular Traps Derived From Macrophages, Mast Cells, Eosinophils and Neutrophils are Generated in a Time-Dependent Manner During Atherothrombosis. J Pathol (2019) 247:505-12. doi: 10.1002/path.5212

264. Goldmann O, Medina E. The Expanding World of Extracellular Traps: Not Only Neutrophils But Much More. Front Immunol (2013) 3:420. doi: 10.3389/fimmu.2012.00420

265. Cerqueira Borges R, Sayuri Hohmann M, Marques Borghi S. Dendritic Cells in COVID-19 Immunopathogenesis: Insights for a Possible Role in Determining Disease Outcome. Int Rev Immunol (2021) 40:108-25. doi: $10.1080 / 08830185.2020 .1844195$

266. Fauriat C, Long EO, Ljunggren H-G, Bryceson YT. Regulation of Human NK-Cell Cytokine and Chemokine Production by Target Cell Recognition. Blood (2010) 115:2167-76. doi: 10.1182/blood-2009-08-238469 
267. Abel AM, Yang C, Thakar MS, Malarkannan S. Natural Killer Cells: Development, Maturation, and Clinical Utilization. Front Immunol (2018) 9:1869. doi: 10.3389/fimmu.2018.01869

268. Ahmed F, Jo D-H, Lee S-H. Can Natural Killer Cells be a Principal Player in Anti-SARS-CoV-2 Immunity? Front Immunol (2020) 11:586765. doi: 10.3389/fimmu.2020.586765

269. Masselli E, Vaccarezza M, Carubbi C, Pozzi G, Presta V, Mirandola P, et al. NK Cells: A Double Edge Sword Against SARS-CoV-2. Adv Biol Reg (2020) 77:100737. doi: 10.1016/j.jbior.2020.100737

270. Maucourant C, Filipovic I, Ponzetta A, Aleman S, Cornillet M, Hertwig L, et al. Natural Killer Cell Immunotypes Related to COVID-19 Disease Severity. Sci Immunol (2020) 5:eabd6832. doi: 10.1126/sciimmunol.abd6832

271. van Eeden C, Khan L, Osman MS, Cohen Tervaert JM. Natural Killer Cell Dysfunction and Its Role in COVID-19. Int J Mol Sci (2020) 21:6351. doi: 10.3390/ijms21176351

272. Osman M, Faridi RM, Sligl W, Shabani-Rad M-T, Dharmani-Khan P, Parker A, et al. Impaired Natural Killer Cell Counts and Cytolytic Activity in Patients With Severe COVID-19. Blood Adv (2020) 4:5035-9. doi: 10.1182/ bloodadvances.2020002650

273. Okeke EB, Uzonna JE. The Pivotal Role of Regulatory T Cells in the Regulation of Innate Immune Cells. Front Immunol (2019) 10:680. doi: 10.3389/fimmu.2019.00680

274. Arce-Sillas A, Álvarez-Luquín DD, Tamaya-Domínguez B, Gomez-Fuentes S, Trejo-García A, Melo-Salas M, et al. Regulatory T Cells: Molecular Actions on Effector Cells in Immune Regulation. J Immunol Res (2016) 2016:1720827. doi: 10.1155/2016/1720827

275. Stephen-Victor E, Das M, Karnam A, Pitard B, Gautier J-F, Bayry J. Potential of Regulatory T-Cell-Based Therapies in the Management of Severe COVID19. Eur Respir J (2020) 56:2002182. doi: 10.1183/13993003.02182-2020

276. Meckiff BJ, Ramírez-Suástegui C, Fajardo V, Chee SJ, Kusnadi A, Simon H, et al. Imbalance of Regulatory and Cytotoxic SARS-CoV-2-Reactive $\mathrm{CD}^{+}{ }^{+} \mathrm{T}$ Cells in COVID-19. Cell (2020) 183:1340-53. doi: 10.1016/j.cell.2020.10.001

277. de Candia P, Prattichizzo F, Garavelli S, Matarese G. T Cells: Warriors of SARS-CoV-2 infection. Trends Immunol (2021) 42:18-30. doi: 10.1016/ j.it.2020.11.002

278. Lawand M, Déchanet-Merville J, Dieu-Nosjean M-C. Key Features of Gamma-Delta T-Cell Subsets in Human Diseases and Their Immunotherapeutic Implications. Front Immunol (2017) 8:761. doi: 10.3389/fimmu.2017.00761

279. Ribot JC, Lopes N, Silva-Santos B. $\gamma \delta$ T Cells in Tissue Physiology and Surveillance. Nat Rev Immunol (2021) 21:221-32. doi: 10.1038/s41577-02000452-4

280. Caron J, Ridgley LA, Bodman-Smith M. How to Train Your Dragon: Harnessing Gamma Delta T Cells Antiviral Functions and Trained Immunity in a Pandemic Era. Front Immunol (2021) 12:666983. doi: 10.3389/fimmu.2021.666983

281. Coquet JM, Chakravarti S, Kyparissoudis K, McNab FW, Pitt LA, McKenzie BS, et al. Diverse Cytokine Production by NKT Cell Subsets and Identification of an IL-17-Producing CD4-NK1.1- NKT Cell Population. Proc Natl Acad Sci USA (2008) 105:11287-92. doi: 10.1073/pnas.0801631105

282. Liu J, Yang X, Wang H, Li Z, Deng H, Liu J, et al. Analysis of the Long-Term Impact on Cellular Immunity in COVID-19-Recovered Individuals Reveals a Profound NKT Cell Impairment. mBio 12:e00085-21. doi: 10.1128/mBio.00085-2

283. Odak I, Barros-Martins J, Bošnjak B, Stahl K, David S, Wiesner O, et al. Reappearance of Effector T Cells is Associated With Recovery From COVID19. EBioMedicine (2020) 57:102885. doi: 10.1016/j.ebiom.2020.102885

284. Zingaropoli MA, Valentina Perri V, Pasculli P, Cogliati Dezza F, Nijhawan P, Savelloni G, et al. Major Reduction of NKT Cells in Patients With Severe COVID-19 Pneumonia. Clin Immunol (2021) 222:108630. doi: 10.1016/ j.clim.2020.108630

285. Cox MA, Kahan SM, Zajac AJ. Anti-Viral CD8 T Cells and the Cytokines That They Love. Virology (2013) 435:157-69. doi: 10.1016/j.virol.2012.09.012

286. Chen Z, Wherry EJ. T Cell Responses in Patients With COVID-19. Nat Rev Immunol (2020) 20:520-36. doi: 10.1038/s41577-020-0402-6

287. Pelaia C, Tinello C, Vatrella A, De Sarro G, Pelaia G. Lung Under Attack by COVID-19-Induced Cytokine Storm: Pathogenic Mechanisms and Therapeutic Implications. Ther Adv Respir Dis (2020) 14:1-9. doi: 10.1177/ 1753466620933508
288. Fara A, Mitrev Z, Rosalia RA, Assas BM. Cytokine Storm and COVID-19: A Chronicle of Pro-Inflammatory Cytokines. Open Biol (2020) 10:200160. doi: $10.1098 /$ rsob.200160

289. Zhang Y-Y, Li B-R, Ning B-T. The Comparative Immunological Characteristics of SARS-CoV, MERS-CoV, and SARS-CoV-2 Coronavirus Infections. Front Immunol (2020) 11:2033. doi: 10.3389/fimmu.2020.02033

290. Mazzoni A, Salvati L, Maggi L, Capone M, Vanni A, Spinicci M, et al. Impaired Immune Cell Cytotoxicity in Severe COVID-19 is IL-6 Dependent. J Clin Invest (2020) 130:4694-703. doi: 10.1172/JCI138554

291. Gil-Etayo FJ, Suàrez-Fernández P, Cabrera-Marante O, Arroyo D, Garcinuño S, Laura Naranjo L, et al. T-Helper Cell Subset Response is a Determining Factor in COVID-19 Progression. Front Cell Infect Microbiol (2021) 11:624483. doi: 10.3389/fcimb.2021.624483

292. Sattler A, Angermair S, Stockmann H, Heim KM, Khadzhynov D, Treskatsch S, et al. SARS-CoV-2-Specific T Cell Responses and Correlations With COVID-19 Patient Predisposition. J Clin Invest (2020) 130:6477-89. doi: $10.1172 /$ JCI1 40965

293. Sadeghi A, Tahmasebi S, Mahmood A, Kuznetsova M, Valizadeh H, Taghizadieh A, et al. Th17 and Treg Cells Function in SARS-CoV2 Patients Compared With Healthy Controls. J Cell Physiol (2020) 236 (Suppl 1):1-11. doi: 10.1002/jcp.30047

294. Hodgson SH, Mansatta K, Mallett G, Harris V, Emary KRW, Pollard AJ. What Defines an Efficacious COVID-19 Vaccine? A Review of the Challenges Assessing the Clinical Efficacy of Vaccines Against SARS-CoV2. Lancet Infect Dis (2021) 21:e26-35. doi: 10.1016/S1473-3099(20)30773-8

295. Dai L, Gao GF. Viral Targets for Vaccines Against COVID-19. Nat Rev Immunol (2020) 1-10. doi: 10.1038/s41577-020-00480-0

296. Gao Q, Bao L, Mao H, Wang L, Xu K, Yang M, et al. Development of an Inactivated Vaccine Candidate for SARS- CoV-2. Science (2020) 369:77-81. doi: $10.1126 /$ science.abc1932

297. Zhang Y, Zeng G, Pan H, Li C, Hu Y, Chu K, et al. Safety, Tolerability, and Immunogenicity of an Inactivated SARS- CoV-2 Vaccine in Healthy Adults Aged 18-59 Years: A Randomised, Double- Blind, Placebo- Controlled, Phase 1/2 Clinical Trial. Lancet Infect Dis (2021) 21:181-92. doi: 10.1016/ S1473-3099(20)30843-4

298. Xia S, Duan K, Zhang Y, Zhao D, Zhang H, Xie Z, et al. Effect of an Inactivated Vaccine Against SARS- CoV-2 on Safety and Immunogenicity Outcomes: Interim Analysis of 2 Randomized Clinical Trials. JAMA (2020) 324:951-60. doi: 10.1001/jama.2020.15543

299. Wang H, Zhang Y, Huang B, Deng W, Quan Y, Wang W, et al. Development of an Inactivated Vaccine Candidate, BBIBP- CorV, With Potent Protection Against SARS- CoV-2. Cell (2020) 182:713-21. doi: 10.1016/j.cell.2020.06.008

300. Xia S, Zhang Y, Wang Y, Wang H, Yang Y, Gao GF, et al. Safety and Immunogenicity of an Inactivated SARS- CoV-2 Vaccine, BBIBP- CorV: A Randomised, Double- Blind, Placebo- Controlled, Phase 1/2 Trial. Lancet Infect Dis (2020) 21:39-51. doi: 10.1016/S1473-3099(20)30831-8

301. Zhu F-C, Guan X-H, Li Y-H, Huang J-Y, Jiang T, Hou L-H, et al. Immunogenicity and Safety of a Recombinant Adenovirus Type-5Vectored COVID-19 Vaccine in Healthy Adults Aged 18 Years or Older: A Randomised, Double- Blind, Placebo- Controlled, Phase 2 Trial. Lancet (2020) 396:479-88. doi: 10.1016/S0140-6736(20)31605-6

302. Zhu F-C, Li Y-H, Guan X-H, Hou L-H, Wang W-J, Li J-X, et al. Safety, Tolerability, and Immunogenicity of a Recombinant Adenovirus Type-5 Vectored COVID-19 Vaccine: A Dose- Escalation, Open- Label, nonRandomised, First- in-Human Trial. Lancet (2020) 395:1845-54. doi: $10.1016 /$ S0140-6736(20)31208-3

303. Folegatti PM, Ewer KJ, Aley PK, Angus B, Becker S, Belij-Rammerstorfer S, et al. Safety and Immunogenicity of the ChAdOx1 Ncov-19 Vaccine Against SARS- CoV-2: A Preliminary Report of a Phase 1/2, Single- Blind, Randomised Controlled Trial. Lancet (2020) 396:467-78. doi: 10.1016/ S0140-6736(20)31604-4

304. Ramasamy MN, Minassian AM, Ewer KJ, Flaxman AL, Folegatti PM, Owens DR, et al. Safety and Immunogenicity of ChAdOx1 Ncov-19 Vaccine Administered in a Primeboost Regimen in Young and Old Adults (COV002): A Single- Blind, Randomised, Controlled, Phase 2/3 Trial. Lancet (2020) 396:1979-93. doi: 10.1016/S0140-6736(20)32466-1

305. Logunov DY, Dolzhikova IV, Zubkova OV, Tukhvatulin AI, Shcheblyakov DV, Dzharullaeva AS, et al. Safety and Efficacy of An rAd26 and rAd5 
Vector-Based Heterologous Prime-Boost COVID-19 Vaccine: An Interim Analysis of a Randomised Controlled Phase 3 Trial in Russia. Lancet (2021) 397:671-81. doi: 10.1016/S0140-6736(21)00234-8

306. Jackson LA, Anderson EJ, Rouphael NG, Roberts PC, Makhene M, Coler RN, et al. An mRNA Vaccine Against SARSCoV-2 - Preliminary Report. N Engl J Med (2020) 383:1920-31. doi: 10.1056/NEJMoa2022483

307. Anderson EJ, Rouphael NG, Widge AT, Jackson LA, Roberts PC, Makhene $\mathrm{M}$, et al. Safety and Immunogenicity of SARS-CoV-2 mRNA-1273 Vaccine in Older Adults. N Engl J Med (2020) 383:2427-38. doi: 10.1056/ NEJMoa2028436

308. Walsh EE, Frenck RW, Falsey AR, Kitchin N, Absalon J, Gurtman A, et al. Safety and Immunogenicity of Two RNA-Based Covid-19 Vaccine Candidates. N Engl J Med (2020) 383:2439-50. doi: 10.1056/ NEJMoa2027906

309. Polack FP, Thomas SJ, Kitchin N, Absalon J, Gurtman A, Lockhart S, et al. Safety and Efficacy of the BNT162b2 mRNA Covid-19 Vaccine. N Engl J Med (2020) 383:2603-15. doi: 10.1056/NEJMoa2034577

310. Heath PT, Galiza EP, Baxter DN, Boffito M, Browne D, Burns F, et al. Safety and Efficacy of NVX-CoV2373 Covid-19 Vaccine. N Engl J Med (2021) NEJMoa2107659. doi: 10.1056/NEJMoa2107659

311. Sadoff J, Le Gars M, Shukarev G, Heerwegh D, Truyers C, de Groot AM, et al. Interim Results of a Phase 1-2a Trial of Ad26.COV2.S Covid-19 Vaccine. N Engl J Med (2021) 384:1824-35. doi: 10.1056/NEJMoa2034201

312. Watson A, Kronqvist N, Spalluto CM, Griffiths M, Staples KJ, Wilkinson T, et al. Novel Expression of a Functional Trimeric Fragment of Human SP-A With Efficacy in Neutralization of RSV. Immunobiol (2017) 222:111-8. doi: 10.1016/j.imbio.2016.10.015

313. Clark H, Reid K. The Potential of Recombinant Surfactant Protein D Therapy to Reduce Inflammation in Neonatal Chronic Lung Disease, Cystic Fibrosis, and Emphysema. Arch Dis Child (2003) 88:981-4. doi: 10.1136/adc.88.11.981

314. Sato A, Whittset JA, Scheule RK, Ikegami M. Surfactant Protein-D Inhibits Lung Inflammation Caused by Ventilation in Premature Newborn Lambs. Am J Respir Crit Care Med (2010) 181:1098-105. doi: 10.1164/rccm.200912-1818OC

315. Clark H, Palaniyar N, Strong P, Edmondson J, Hawgood S, Reid KBM. Surfactant Protein D Reduces Alveolar Macrophage Apoptosis In Vivo. J Immunol (2002) 169:2892-9. doi: 10.4049/jimmunol.169.6.2892

316. García-Mouton C, Hidalgo A, Arroyo R, Echalde M, Cruz A, Pérez-Gil J. Pulmonary Surfactant and Drug Delivery: An Interface-Assisted Carrier to Deliver Surfactant Protein SP-D Into the Airways. Front Bioengineer Biotechnol (2021) 8:613276. doi: 10.3389/fbioe.2020.613276

317. Roquilly A, Jacqueline C, Davieau M, Mollé A, Sadek A, Fourgeux C, et al. Alveolar Macrophages are Epigenetically Altered After Inflammation, Leading to Long-Term Lung Immunoparalysis. Nat Immunol (2020) 21:636-48. doi: 10.1038/s41590-020-0673-x

318. Bordon Y. Blocking SIRP $\alpha$ Could Restore Macrophage Appetite and Mitigate Pneumonia. Nat Rev Immunol (2020) 20:349. doi: 10.1038/s41577-020-0339-9

319. Wu Y, Potempa LA, El Kebir D, Filep JG. C-Reactive Protein and Inflammation: Conformational Changes Affect Function. Biol Chem (2015) 396:1181-97. doi: 10.1515/hsz-2015-0149

320. Pepys MB, Hirschfield GM, Tennent GA, Gallimore JR, Kahan MC, Bellotti V, et al. Targeting C-Reactive Protein for the Treatment of Cardiovascular Disease. Nature (2006) 440:1217-21. doi: 10.1038/nature04672

321. Pepys MB. The Pentraxins 1975-2018: Serendipity, Diagnostics and Drugs. Front Immunol (2018) 9:2382. doi: 10.3389/fimmu.2018.02382
322. Kayser S, Brunner P, Althaus K, Dorst J, Sheriff A. Selective Apheresis of CReactive Protein for Treatment of Indications With Elevated CRP Concentrations. J Clin Med (2020) 9:2947. doi: 10.3390/jcm9092947

323. Sheriff A, Kayser S, Brunner P, Vogt B. C-Reactive Protein Triggers Cell Death in Ischemic Cells. Front Immunol (2021) 12:630430. doi: 10.3389/ fimmu.2021.630430

324. Kaveri SV, Silverman GJ, Bayry J. Natural IgM in Immune Equilibrium and Harnessing Their Therapeutic Potential. J Immunol (2012) 188:939-45. doi: $10.4049 /$ jimmunol.1102107

325. Bayry J, Lacroix-Desmazes S, Kazatchkine MD, Kaveri SV. Intravenous Immunoglobulin for Infectious Diseases: Back to the Pre-Antibiotic and Passive Prophylaxis Era? Trends Pharmacol Sci (2004) 25:306-10. doi: 10.1016/j.tips.2004.04.002

326. Nkadi PO, Merritt TA, Pillers D-AM. An Overview of Pulmonary Surfactant in the Neonate: Genetics, Metabolism, and the Role of Surfactant in Health and Disease. Mol Genet Metab (2009) 97:95-101. doi: 10.1016/ j.ymgme.2009.01.015

327. Voelker DR, Numata M. Phospholipid Regulation of Innate Immunity and Respiratory Viral Infection. J Biol Chem (2019) 294:4282-9. doi: 10.1074/ jbc.AW118.003229

328. Haagsman HP, Herias V, van Eijk M. Surfactant Phospholipids and Proteins in Lung Defence. Acta Pharmacol Sin (2003) 24:1301-3.

329. Al-Qahtani AA, Murugaiah V, Bashir HA, Pathan AA, Abozaid SM, Makarov E, et al. Full-Length Human Surfactant Protein A Inhibits Influenza A Virus Infection of A549 Lung Epithelial Cells: A Recombinant Form Containing Neck and Lectin Domains Promotes Infectivity. Immunobiol (2019) 224:408-18. doi: 10.1016/j.imbio.2019.02.006

330. Litvack ML, Palaniyar N. Review: Soluble Innate Immune PatternRecognition Proteins for Clearing Dying Cells and Cellular Components: Implications on Exacerbating or Resolving Inflammation. Innate Immun (2010) 16:191-200. doi: 10.1177/1753425910369271

331. Qian Z, Travanty EA, Oko L, Edeen K, Berglund A, Wang J, et al. Innate Immune Response of Human Alveolar Type II Cells Infected With Severe Acute Respiratory Syndrome-Coronavirus. Am J Respir Cell Mol Biol (2013) 48:742-8. doi: $10.1165 / \mathrm{rcmb} .2012-03390 \mathrm{OC}$

332. Jonsdottir HR, Dijkman R. Coronavirus and the Human Airway: A Universal System for Virus-Host Interaction Studies. Virol J (2016) 13:24. doi: 10.1186/ s12985-016-0479-5

Conflict of Interest: The authors declare that the research was conducted in the absence of any commercial or financial relationships that could be construed as a potential conflict of interest.

Publisher's Note: All claims expressed in this article are solely those of the authors and do not necessarily represent those of their affiliated organizations, or those of the publisher, the editors and the reviewers. Any product that may be evaluated in this article, or claim that may be made by its manufacturer, is not guaranteed or endorsed by the publisher.

Copyright $\odot 2021$ Labarrere and Kassab. This is an open-access article distributed under the terms of the Creative Commons Attribution License (CC BY). The use, distribution or reproduction in other forums is permitted, provided the original author(s) and the copyright owner(s) are credited and that the original publication in this journal is cited, in accordance with accepted academic practice. No use, distribution or reproduction is permitted which does not comply with these terms. 